\title{
Molecular and Biochemical Analysis of Calreticulin in Solanum lycopersicum
}

\author{
Fatme Lezzeik
}

A thesis submitted to the Faculty of Graduate Studies and Research of Carleton University in partial fulfillment of the requirement for the degree of Master of Science in Biology.

\author{
Carleton University \\ Canada \\ (C) 2013, Fatme Lezzeik
}


Library and Archives

Canada

Published Heritage

Branch

395 Wellington Street

Ottawa ON K1A ON4

Canada
Bibliothèque et

Archives Canada

Direction du

Patrimoine de l'édition

395 , rue Wellington

Ottawa ON K1A ON4

Canada
Your file Votre référence

ISBN: 978-0-494-94633-6

Our file Notre référence

ISBN: $978-0-494-94633-6$
NOTICE:

The author has granted a nonexclusive license allowing Library and Archives Canada to reproduce, publish, archive, preserve, conserve, communicate to the public by telecommunication or on the Internet, loan, distrbute and sell theses worldwide, for commercial or noncommercial purposes, in microform, paper, electronic and/or any other formats.

The author retains copyright ownership and moral rights in this thesis. Neither the thesis nor substantial extracts from it may be printed or otherwise reproduced without the author's permission.
AVIS:

L'auteur a accordé une licence non exclusive permettant à la Bibliothèque et Archives Canada de reproduire, publier, archiver, sauvegarder, conserver, transmettre au public par télécommunication ou par l'Internet, prêter, distribuer et vendre des thèses partout dans le monde, à des fins commerciales ou autres, sur support microforme, papier, électronique et/ou autres formats.

L'auteur conserve la propriété du droit d'auteur et des droits moraux qui protege cette thèse. $\mathrm{Ni}$ la thèse ni des extraits substantiels de celle-ci ne doivent être imprimés ou autrement reproduits sans son autorisation.
In compliance with the Canadian Privacy Act some supporting forms may have been removed from this thesis.

While these forms may be included in the document page count, their removal does not represent any loss of content from the thesis.
Conformément à la loi canadienne sur la protection de la vie privée, quelques formulaires secondaires ont été enlevés de cette thèse.

Bien que ces formulaires aient inclus dans la pagination, il n'y aura aucun contenu manquant. 


\section{Acknowledgments}

My deepest gratitude and thanks go to my supervisor Dr. Tim Xing for giving me the opportunity to be part of his lab in seeking a graduate degree. Dr. Xing, thank you for your support and help through this journey. Thank you for your patience, guidance, humbleness and most importantly for your encouragement.

I would also like to thank the members of my advisory committee Dr. Steve Gleddie and Dr. John Arnason. Your advice and suggestions were invaluable in helping me pave my way.

To everyone in the Xing lab, thank you for making this an enjoyable experience. In particular, I would like to thank Yasamin for the endless hours of discussions and planning as well as the late hours we spent together working in the lab.

Finally, I would like to thank my family and especially my parents for their constant encouragement and for always being there for me. 


\section{Table of Contents}

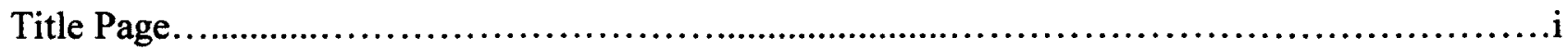

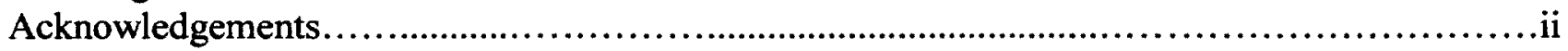

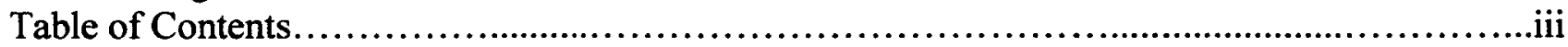

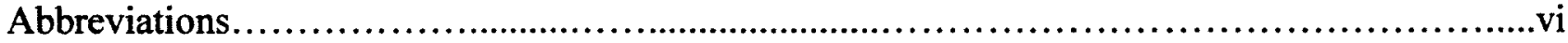

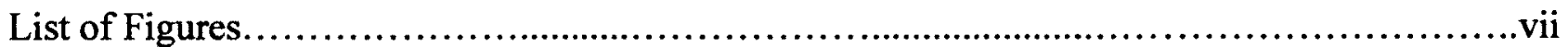

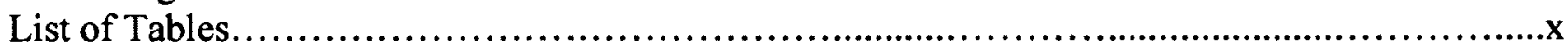

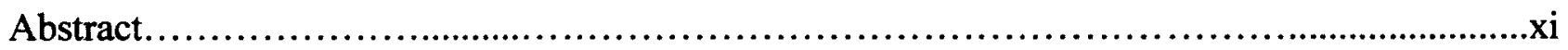

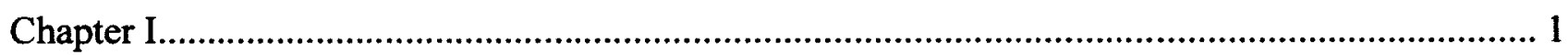

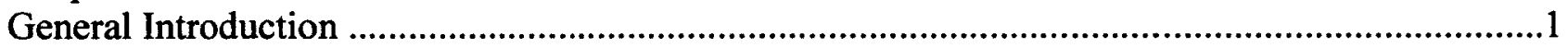

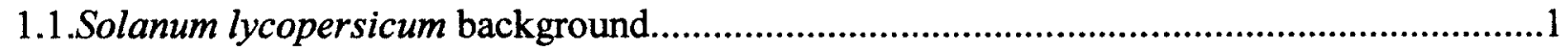

1.2. Signal transduction and response

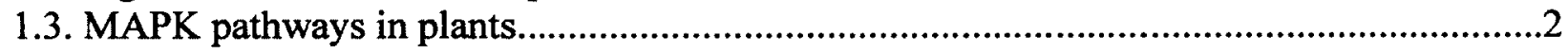

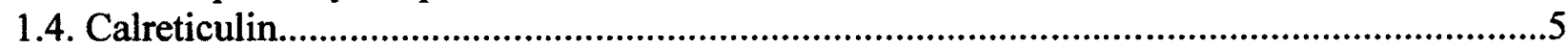

1.5. CRT and MAPK

1.6. $\beta$-1, 3-glucanase

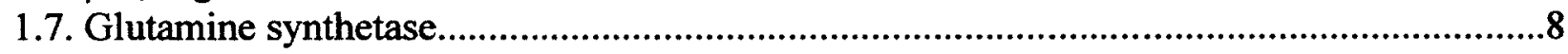

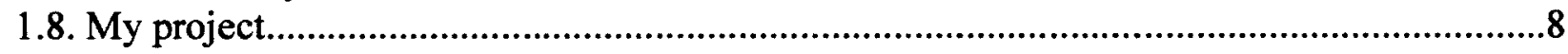

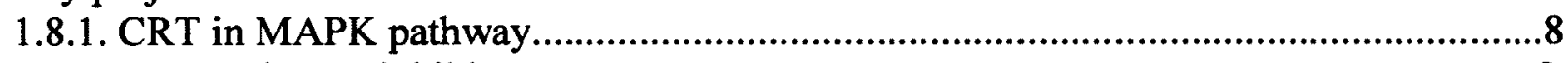

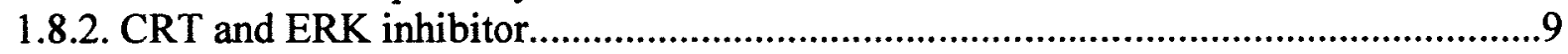

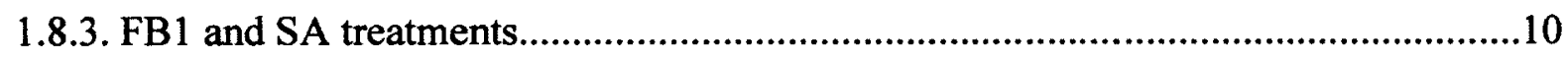

1.8.4. Unfolded protein response and CRT........................................................................10

1.8.5. CRT expression cloning for protein-protein interaction analysis.............................11

1.8.6. Enzyme assays...........................................................................................................11

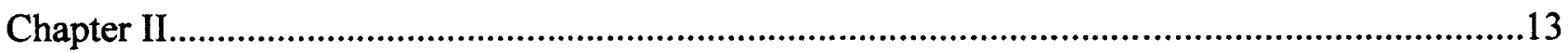

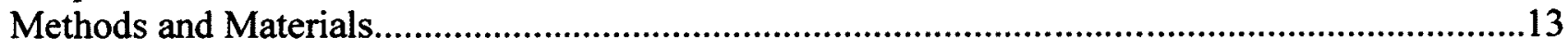

2.1.Plant materials and growth conditions..........................................................................13

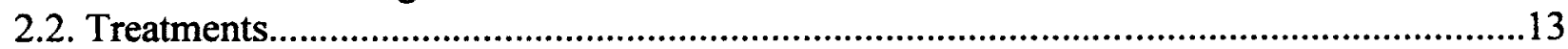

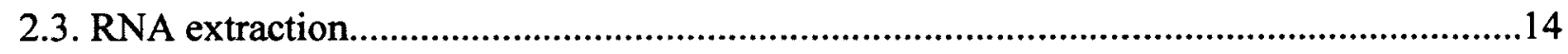

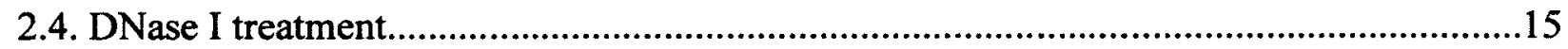

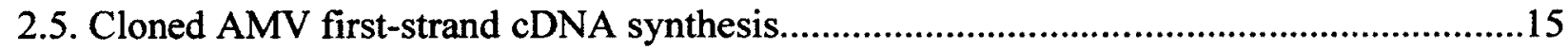

2.6. Reverse transcriptase polymerase chain reaction (RT-PCR)...........................................16

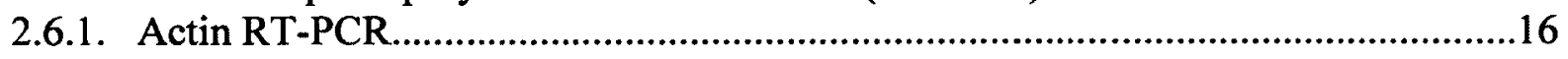

2.6.2. CRT RT-PCR

2.7. Cloning CRT gene into pET14b vector.......................................................................17

2.7.1. Producing the Blunt-End PCR products...............................................................17

2.7.2. Cloning into TOPO vector...................................................................................... 18

2.7.3. Digesting the insert and vector to produce the sticky (cohesive) ends....................20

2.7.3.1. Double digestion of CRT insert........................................................................21

2.7.3.2. Double digestion of $\mathrm{pET} 14 \mathrm{~b}$ vector......................................................................21

2.7.4. Ligating the double digested CRT insert and $\mathrm{pET} 14 \mathrm{~b}$ vector.................................22

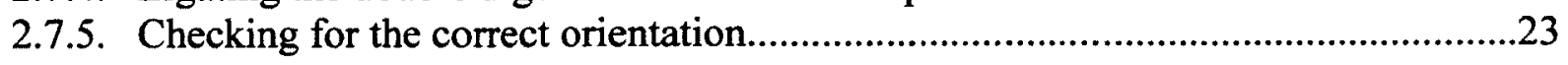




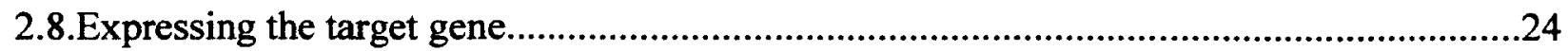

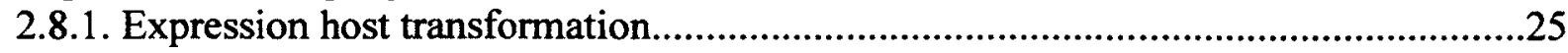

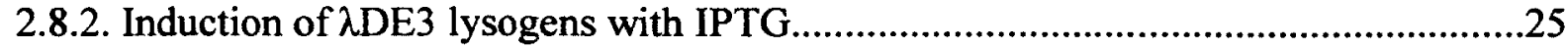

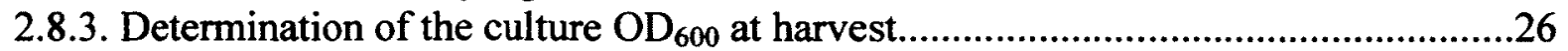

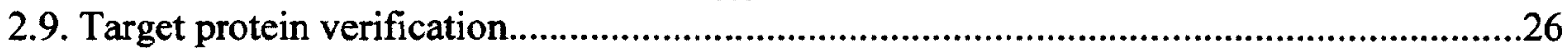

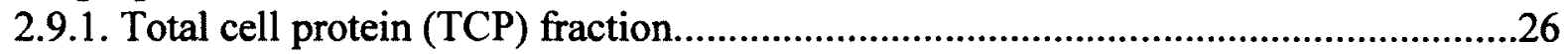

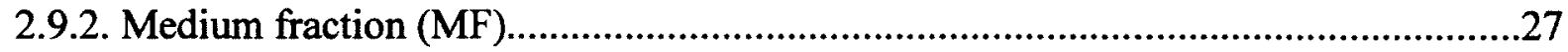

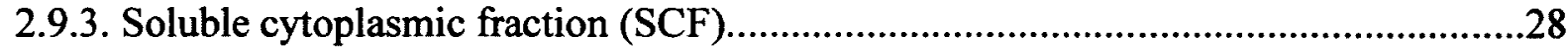

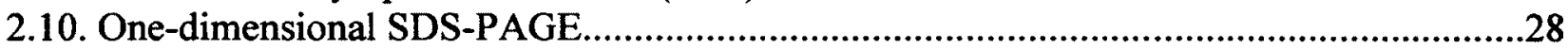

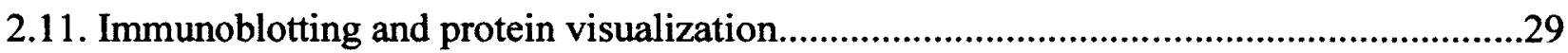

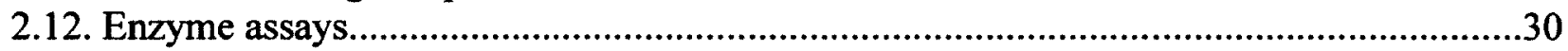

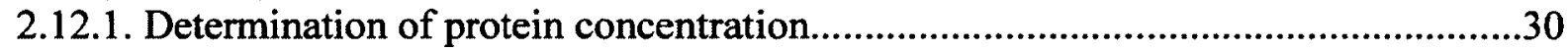

2.12.2. $\beta-1$, 3-glucanase assay........................................................................................

2.12.3. Glutamine synthetase assay............................................................................

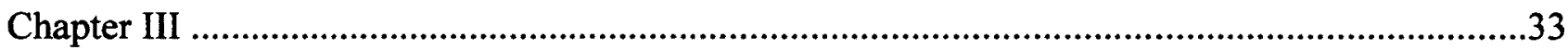

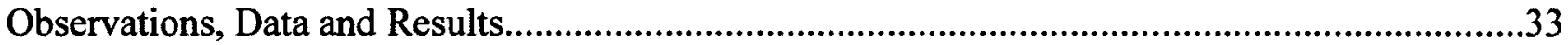

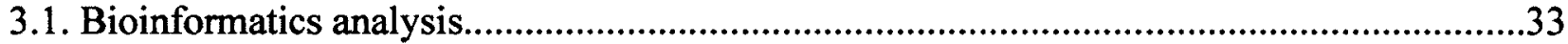

3.1.1. Phylogenetic tree of CRT in Solanum lycopersicum and Arabidopsis thaliana.......33

3.1.2. Analysis of Solanum lycopersicum LeCRT1 and its Arabidopsis homolog...............34

3.1.3. Analysis of Solanum lycopersicum LeCRT2 and its Arabidopsis homolog..............40

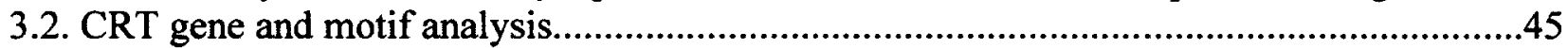

3.3. Solanum lycopersicum plant growth and leaf treatment......................................................

3.4. Finding the appropriate annealing temperature for CRT primers.......................................49

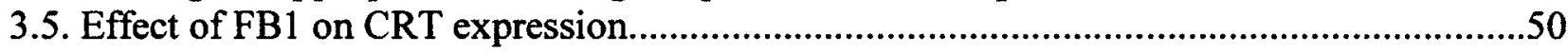

3.6. Effect of ERK inhibitor (ERKi) on CRT expression......................................................50

3.6.1. Normalization of CRT expression using actin gene...............................................50

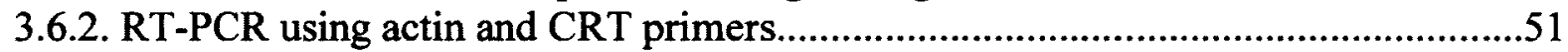

3.7. Endoplasmic reticulum (ER) stress-inducing agents (TM and DTT) ...............................51

3.7.1. Normalization of CRT expression using actin gene..................................................51

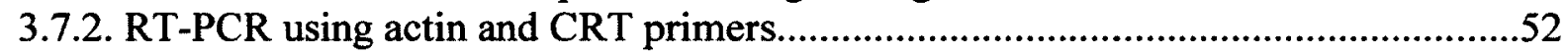

3.7.3. Statistical analysis of significance of SA treatment on CRT...................................52

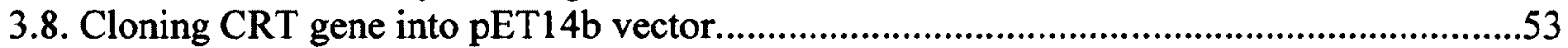

3.8.1. Producing the blunt-end PCR products..................................................................53

3.8.2. Cloning into TOPO vector.....................................................................................5

3.8.3. Digesting the insert and pET14b vector to produce the sticky (cohesive) ends.......56

3.8.3.1. Double digestion of CRT insert.....................................................................56

3.8.3.2. Double digestion of $\mathrm{pET14b}$ vector.....................................................................58

3.8.4. Ligating the double digested CRT insert and $\mathrm{pET} 14 \mathrm{~b}$ vector..................................59

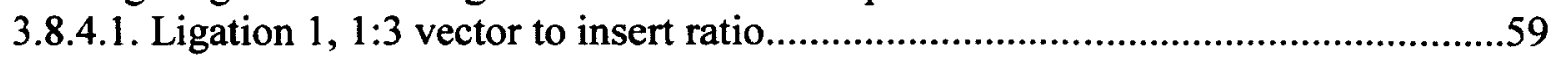

3.8.4.2. Ligation $2,1: 1$ vector to insert ratio..............................................................60

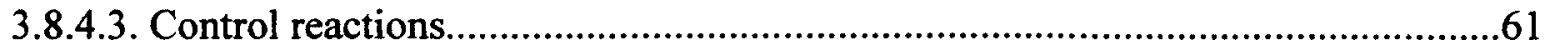

3.8.4.4. Transformation efficiency of BL21 cells..........................................................62

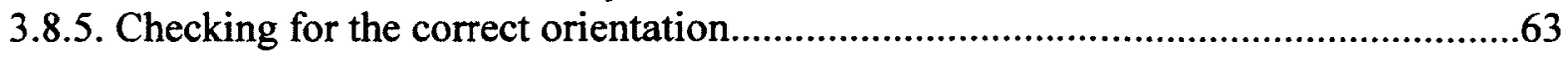

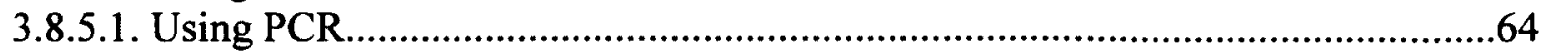

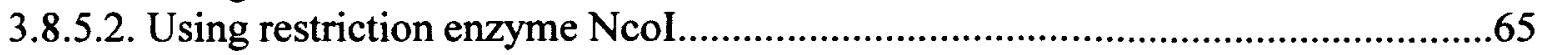




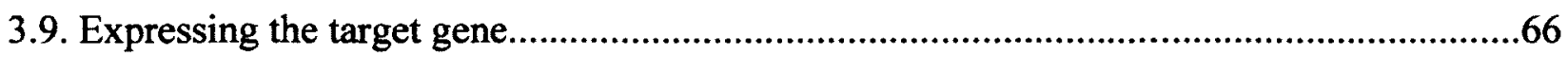

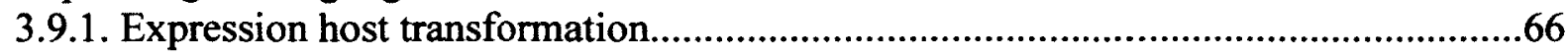

3.9.2. Determination of the culture $\mathrm{OD}_{600}$ at harvest........................................................67

3.9.3. Normalized SDS-PAGE gel................................................................................68

3.9.4. Detecting and quantifying target proteins................................................................68

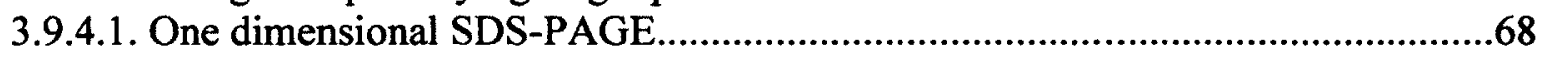

3.9.4.2. Immunobloting and protein visualization.........................................................70

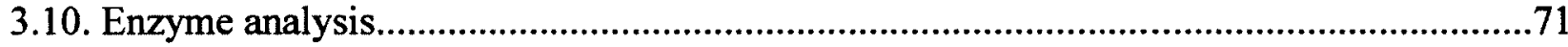

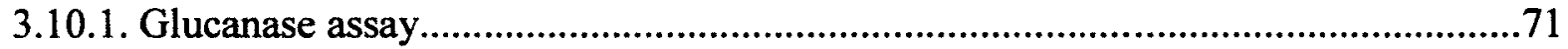

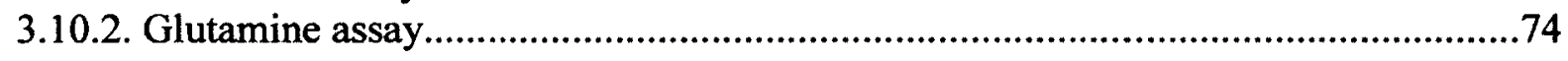

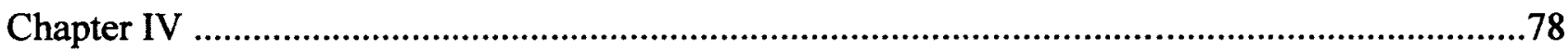

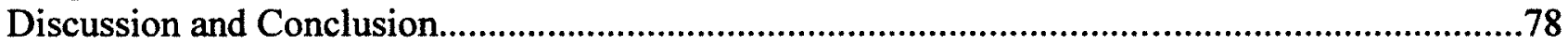

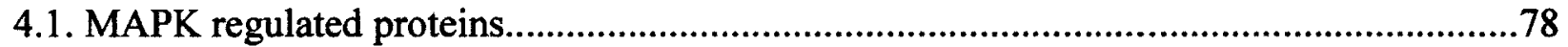

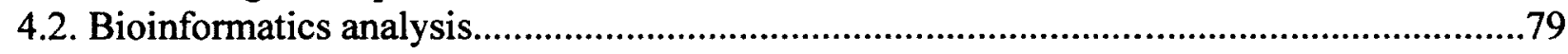

4.3. Analysis of Solanum lycopersicum CRT and its Arabidopsis homolog...........................80

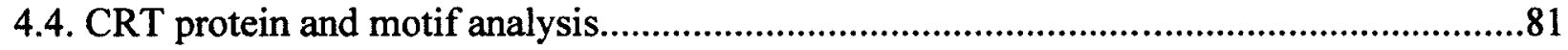

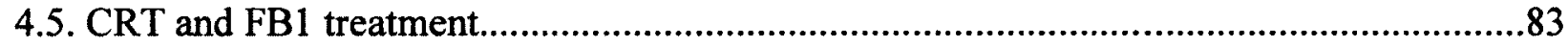

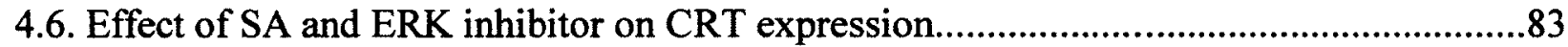

4.7. Endoplasmic reticulum (ER) stress-inducing agents (TM and DTT) ...............................84

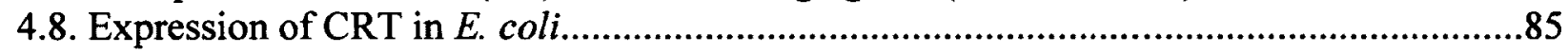

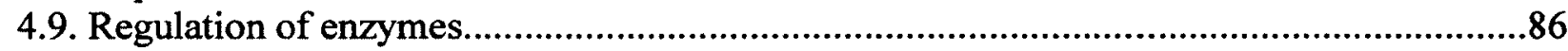

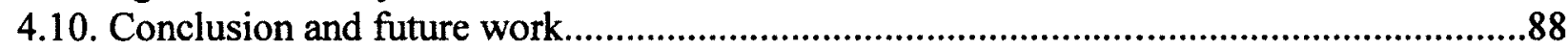

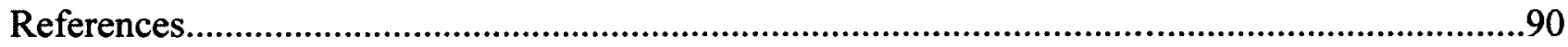




\begin{abstract}
Abbreviations
\end{abstract}
BLAST: Basic Local Alignment Search Tool

CRT: calreticulin

cDNA: complementary DNA

DEPC: diethylpyrocarbonate

DTT: dithiothreitol

ER: endoplasmic reticulum

ECL: enhanced chemiluminescence

EDTA: ethylenediamine tetraacetic acid

ERK: extracellular signal-regulated kinases

FB1: Fumonisin B1

kb: kilobase

kDa: kilo Dalton

MAPK: mitogen-activated pProtein kinase

mRNA: messenger RNA

NCBI: National Center for Biotechnology Information

PR: pathogenesis-related

PAGE: polyacrylamide gel electrophoresis

PCR: polymerase chain reaction

PVDF: polyvinylidine fluoride

RT-PCR: reverse transcriptase polymerase chain reaction

SA: salicylic acid

SDS: sodium dodecyl sulphate

TM: tunicamycin

TEMED: N,N,N',N'-tetramethylethylenediamine

UPR: unfolded protein response 


\section{List of Figures}

\section{Chapter I}

Figure 1.1: Representation of mitogen-activated protein kinase signal transduction cascades.

Figure 1.2: Diagram comparing the structure of both calreticulin and calnexin.

\section{Chapter II}

Figure 2.1: pET14b vector map with restriction sites and characteristics.

\section{Chapter III}

Figure 3.1: Phylogenetic tree of Arabidopsis thaliana and Solanum lycopersicum CRT genes.

Figure 3.2: High stringency ScanSite output for AtCRT1a protein sequence indicating possible ERK docking and binding sites.

Figure 3.3: Effect of FB1 or SA on AtCRT1a of Arabidopsis thaliana.

Figure 3.4: Expression levels of LeCRT1 (AK321700.1) in leaves of Solanum lycopersicum at different development stages.

Figure 3.5: Overall expression of LeCRT1 (AK321700.1) gene across different stages in development.

Figure 3.6: Proteins that are predicted to co-occur with AtCRT1a.

Figure 3.7: High stringency ScanSite output for AtCRT1b protein sequence indicating possible ERK docking and binding sites.

Figure 3.8: Effect of chemical treatment FB1 or hormone SA on AtCRT1b of Arabidopsis thaliana.

Figure 3.9: Expression levels of AtCRT1b in rosette leaves of Arabidopsis thaliana at different development stages.

Figure 3.10: Overall expression of AtCRT1b gene across different stages in development..

Figure 3.11: Proteins that are predicted to co-occur with AtCRT1b.

Figure 3.12: Nucleotide sequence and the corresponding amino acid sequence of tomato CRT gene.

Figure 3.13: Amino acid alignment of CRT of Solanum lycopersicum SGN-U578018 and Arabidopsis thaliana AT1G09210_1 and AT1G56340_1.

Figure 3.14: Images taken by a digital camera of different batches of three week old Solanum lycopersicum plants grown in the growth chamber under long day conditions of $16 \mathrm{~h}$ light and $8 \mathrm{~h}$ dark. 
Figure 3.15: Examples of some platted leaves treated for $0 \mathrm{~h}$ or $48 \mathrm{~h}$ after which the leaves were frozen with liquid nitrogen.

Figure 3.16: The gradient of temperatures ranging from $55.0^{\circ} \mathrm{C}$ to $64.0^{\circ} \mathrm{C}$ in order to find the best annealing temperature for RT-PCR primers to amplify CRT.

Figure 3.17: RT-PCR determination of the expression of CRT gene for Solanum lycopersicum.

Figure 3.18: RT-PCR determination of the expression of CRT gene for two batches grown under the same conditions at different times.

Figure 3.19: Expression of actin and CRT genes for two batches grown under the same conditions at different times.

Figure 3.20: The integrated density value (IDV) showing the expression of CRT gene under each treatment $\mathrm{H}_{2} \mathrm{O}$ and $\mathrm{SA}$ at both $0 \mathrm{hr}$ and $48 \mathrm{hr}$ incubation with respective standard errors.

Figure 3.21: (A) Amplification of CRT by Pfx polymerase enzyme. (B) The recovery of CRT gene in (A) after gene clean by Wizard\& SV Gel and PCR Clean-Up System.

Figure 3.22: (A) The expression of control PCR product amplified by Pfx polymerase enzyme and (B) the recovery of that control product after gene clean by Wizard $B$ SV Gel and PCR Clean-Up System.

Figure 3.23: Transformation of TOPO reactions in $\mathrm{Mach} 1^{\mathrm{TM}}-\mathrm{T} 1^{\mathrm{R}}$ cells plated on LB medium with $50 \mu \mathrm{g} / \mathrm{mL}$ kanamycin antibiotic.

Figure 3.24: Amplification of CRT2 gene after cloning into TOPO vector and recovering by plasmid prep. Each lane represents a different single colony.

Figure 3.25: Undigested and double digested CRT insert and TOPO vector by NdeI and XhoI restriction enzymes.

Figure 3.26: Digested pET14b vector with NdeI restriction enzyme for $2 \mathrm{hr}$ at $37^{\circ} \mathrm{C}$.

Figure 3.27: Double digested pET14b vector with NdeI and XhoI restriction enzymes before the addition of CIAP enzyme.

Figure 3.28: Double digested pET14b vector with NdeI and Xhol restriction enzymes after the addition of CIAP enzyme.

Figure 3.29: $15 \mu \mathrm{L}$ (left) and 50 $\mathrm{L}$ (right) plating of ligations 1 transformed in BL21 cells.

Figure 3.30: $15 \mu \mathrm{L}$ (left) and 50 $\mathrm{L}$ (right) plating of ligations 2 transformed in BL21 cells.

Figure 3.31: $15 \mu \mathrm{L}$ and $50 \mu \mathrm{L}$ platting of controls 1 and 2 of ligation 1.

Figure 3.32: The transformation effeciency of BL21 competent cells determined using pUC18 test plasmid. 
Figure 3.33: Positive PCR reactions to check for the correct orientation of the CRT insert ligated in $\mathrm{pET} 14 \mathrm{~b}$ plasmid.

Figure 3.34: Negative PCR reactions to check the orientation of the CRT insert ligated in the pET14b vector.

Figure 3.35: 850bps small band and 4964bps large band obtained by digestion with NcoI restriction enzyme.

Figure 3.36: Plating of $150 \mu \mathrm{L}$ and $200 \mu \mathrm{L}$ of the target gene transformed into BL21-CodonPlus (DE3)-RIPL competent cells on $100 \mu \mathrm{g} / \mathrm{mL}$ carbenicillin and $30 \mu \mathrm{g} / \mathrm{mL}$ chloramphenicol LB plates.

Figure 3.37: 15\% SDS-PAGE analysis of cell extracts followed by Coomassie blue staining.

Figure 3.38: 10\% SDS-PAGE analysis of cell extracts followed by Coomassie blue staining.

Figure 3.39: Immunoblotting of the extracts visualized by chemiluminescence (ECL) system.

Figure 3.40: Glucanase percentage relative activity (\%) of salicylic acid (SA) treatment with respect to water treatment at $0 \mathrm{hr}$.

Figure 3.41: Glucanase percentage relative activity (\%) of tunicamaycin (TM) treatment with respect to water treatment at $0 \mathrm{hr}$.

Figure 3.42: Glucanase percentage relative activity (\%) of dithiothreitol (DTT) treatment with respect to water treatment at $0 \mathrm{hr}$.

Figure 3.43: Glutamine percentage relative activity (\%) of salicylic acid (SA) treatment with respect to water treatment at $0 \mathrm{hr}$.

Figure 3.44: Glutamine percentage relative activity (\%) of tunicamycin (TM) treatment with respect to water treatment at $0 \mathrm{hr}$.

Figure 3.45: Glutamine percentage relative activity (\%) of Dithiothreitol (DTT) treatment with respect to water treatment at $0 \mathrm{hr}$. 


\section{List of Tables}

\section{Chapter II}

Table 2.1: The different treatments used along with their corresponding concentrations.

Table 2.2: The relative solutions and volumes $(\mu \mathrm{L})$ used to perform the TOPO cloning reaction in which CRT gene was inserted into the plasmid vector.

Table 2.3: The relative solutions and volumes $(\mu \mathrm{L})$ used to perform the control TOPO cloning reaction.

\section{Chapter III}

Table 3.1: Summary of mode of prediction and function of proteins that co-occur with AtCRT1a Table 3.2: Summary of mode of prediction and function of proteins that co-occur with AtCRT1b. Table 3.3: The concentrations (ng/ $\mu \mathrm{L}$ ) of the TOPO plasmids containing CRT gene inserts.

Table 3.4: The concentration $(\mathrm{ng} / \mu \mathrm{L})$ of the ligated $\mathrm{CRT}$ insert and $\mathrm{pET} 14 \mathrm{~b}$ vector recovered by plasmid preparation.

Table 3.5: Determination of $\mathrm{OD}_{600}$ at harvest for both the induced and uninduced cultures.

Table 3.6: Determination of the normalized volume of sample to load on a 10-well SDS-PAGE gel. 


\begin{abstract}
Calreticulin (CRT) deals with misfolded proteins by binding to them and marking them for degradation so that only the properly folded proteins are allowed to move away from the ER. The phosphorylation level of CRT is enhanced when a tomato mitogen-activated protein kinase kinase (MAPKK) is activated. It is predicted that a downstream mitogen-activated protein kinase (MAPK) may mediate this phosphorylation. Here we try to find if there is a connection between CRT and MAPK pathway. Salicylic acid (SA) treatment enhanced the expression in CRT gene in tomato. Moreover, once the inhibitor of the ERK sub-group of MAPK was applied, CRT was no longer expressed even in the presence of SA. This indicated that CRT expression is dependent on ERK and is therefore involved in MAPK pathway. In addition, the unfolded protein response (UPR) caused by endoplasmic reticulum (ER) stress was induced by tunicamycin (TM) or dithiothreitol (DTT). The effect on the expression of CRT gene was examined when these stresses were induced individually as well as when combined with SA. CRT expression increased in each case indicating that CRT, being a chaperone, is activated or signals the activation of other chaperones for UPR due to ER stress. Expression cloning of CRT in E.coli was conducted and the expression of CRT protein was examined by SDS-PAGE and Western blotting. CRT is predicted to interact with other molecules involved in protein misfolding like BiP or SHD. Pathogenesis will cause the synthesis of some proteins to slow down so the plant can spend more energy and resources to deal with the stress instead. We examined two enzymes, $\beta$-1,3-glucanase (PR2) and glutamine synthetase, under stress treatment. Glucanase is an important enzyme involved in pathogen cell wall degradation and increases during plant defense responses. The SA effect was inconclusive because of the high standard errors and neither TM nor DTT seemed to increase PR2 levels indicating that UPR is not involved in elevating PR2. Glutamine has several biochemical functions in the cell including protein synthesis and nitrogen donation. Glutamine synthesis decreased, as expected, when the leaves were treated with SA, TM or DTT stress.
\end{abstract}




\section{Chapter I}

\section{General Introduction}

\subsection{Solanum lycopersicum background}

Tomato (Solanum lycopersicum) is recognized as one of the most significant edible plants. For this reason, the productivity and quality of tomato has been improved by breeding. Particularly, resistance to biotic and abiotic stresses has been studied. Tomato has many interesting features like fleshy fruit, a sympodial shoot, and compound leaves. These characteristics are not present in rice and Arabidopsis for example thus making tomato interesting for research purposes. In addition to tomato being in close relationship with other well-known plants like potato, eggplant, pepper, and tobacco, it belongs to the Solanaceae family. Tomato is a herbaceous plant with highly divided leaves that have long, slender hairs with a distinguishing scent. Therefore, the more knowledge we can obtain on studying tomato, the more we will know on those plants as well. Consequently, tomato serves as a model organism for the family Solanaceae (Kimura and Sinha, 2008).

\subsection{Signal transduction and response}

Plant growth and development are affected by different environmental and hormonal stimuli. For instance, plants can acclimatize and live while enduring biotic and abiotic stress conditions. Some of these conditions include drought, salinity, change in $\mathrm{pH}$ of soil, and possible injuries caused by the wind for instance as well as fungal, viral and bacterial infections (Anil and Rao, 2001). These stimuli result in different signals which induce specific responses in plants. In order to sense and transduce these signals, plants need mechanisms or signal transduction pathways that will allow them to respond to these many stimuli (Poovaiah and Reddy, 1993). In 
fact, these signals are dependent on the stimulus itself as well as on the method by which the intracellular mechanism alters the environmental stimulus into a biological one. Presently, extensive research in plant cell physiology is devoted for detailed clarification of stimulusresponse coupling which involve second messengers and phosphorylation.

Second messengers are molecules that act as a means of communication in cells transmitting signals from receptors on the cell surface to target molecules inside the cell, in the cytoplasm or the nucleus. Once they pass on the signals of hormones or growth factors, they cause a type of change in the activity of the cell. This leads to significantly amplifying the strength of the signal. Thus, secondary messengers are a main element of signal transduction cascades.

Protein phosphorylation is vital in regulating and coordinating pathways in plants to respond to stresses as well as regulate protein functions in cells. The behaviour of a protein can be changed when it is phosphorylated including its half life, intrinsic biological behaviour, subcellular location and docking with other proteins or DNAs (Xing et al., 2002). Therefore, phosphorylation is necessary to integrate signals within the cell and thus many kinases, phosphatases, and other molecules involved in phosphorylation pathways have been studied. The mitogen-activated protein kinase (MAPK) pathway is identified as one of the key phosphorylation pathways. (Zhang and Klessig, 2001; Xing et al., 2002).

\subsection{MAPK pathways in plants}

In order for eukaryotes to be able to transduce extracellular signals to intracellular targets, mitogen-activated protein kinase (MAPK) pathways are involved. Diverse extracellular stimuli regulate these different MAPK pathways. Specifically, MAPKs in plants are implicated in signalling abiotic stresses, pathogens and even plant hormones. It has been evident that there are 
many variable MAPKs that have been broadly used by plants for centuries now (Jonak et al., 1999). This ability to sense stress signals and transduce them to proper responses is critical for the plants to adapt, survive, and particularly establish resistance to pathogens (Pitzschke, 2009).

Generally, when a mitogen binds to the membrane ligand, GDP of Ras is phosphorylated to GTP which can now activate MAPKKK (like Raf) which can in turn activate MAPKK that activates MAPK. MAPK can then activate a transcription factor (example myc) which may enter the nucleus and signal DNA transcription until otherwise is indicated. Note that if a mutation occurs in one of the proteins in this pathway, the cell response will either stay on or off in which case cancer may develop (Orton et al., 2005).

On a detailed level, an extracellular epidermal growth factor (EGF) binds to the epidermal growth factor receptor (EGFR) allowing it to be phosphorylated at the tyrosine residue by tyrosine kinase. A guanine nucleotide exchange factor $\mathrm{SOS}$ then binds to the $\mathrm{SH} 3$ domains of GRB2 forming a complex. Binding of this GRB2-SOS complex to the phosphorylated tyrosine residues at SH2 domains of GRB2 activates SOS which in turn activates Ras by removing GDP allowing GTP to bind instead (Schulze et al., 2005). This now starts a kinase cascade where one protein activates another through phosphorylation for the purpose of signal amplification or even feedback. By kinase phosphorylation, activated Ras can now activate Raf (MAPKKK) which can activate MEK (MAPKK) which in turn can activate ERK (MAPK). MAPK then carries on and phosphorylates many other proteins (40S ribosomal protein S6 kinase (RSK) for example) and transcription factors (like C-myc) thus regulating transcription and translation in cells (Zarich $e t$ al., 2006). For instance, the tobacco salicylic-acid induced protein kinase (SIPK, Zhang and Klessig, 1997) is one of the most widely distinguished MAPKs. Studies suggest SIPK has a crucial function in induction of defense responses (Yang et al., 2001; Zhang and Liu, 2001). 


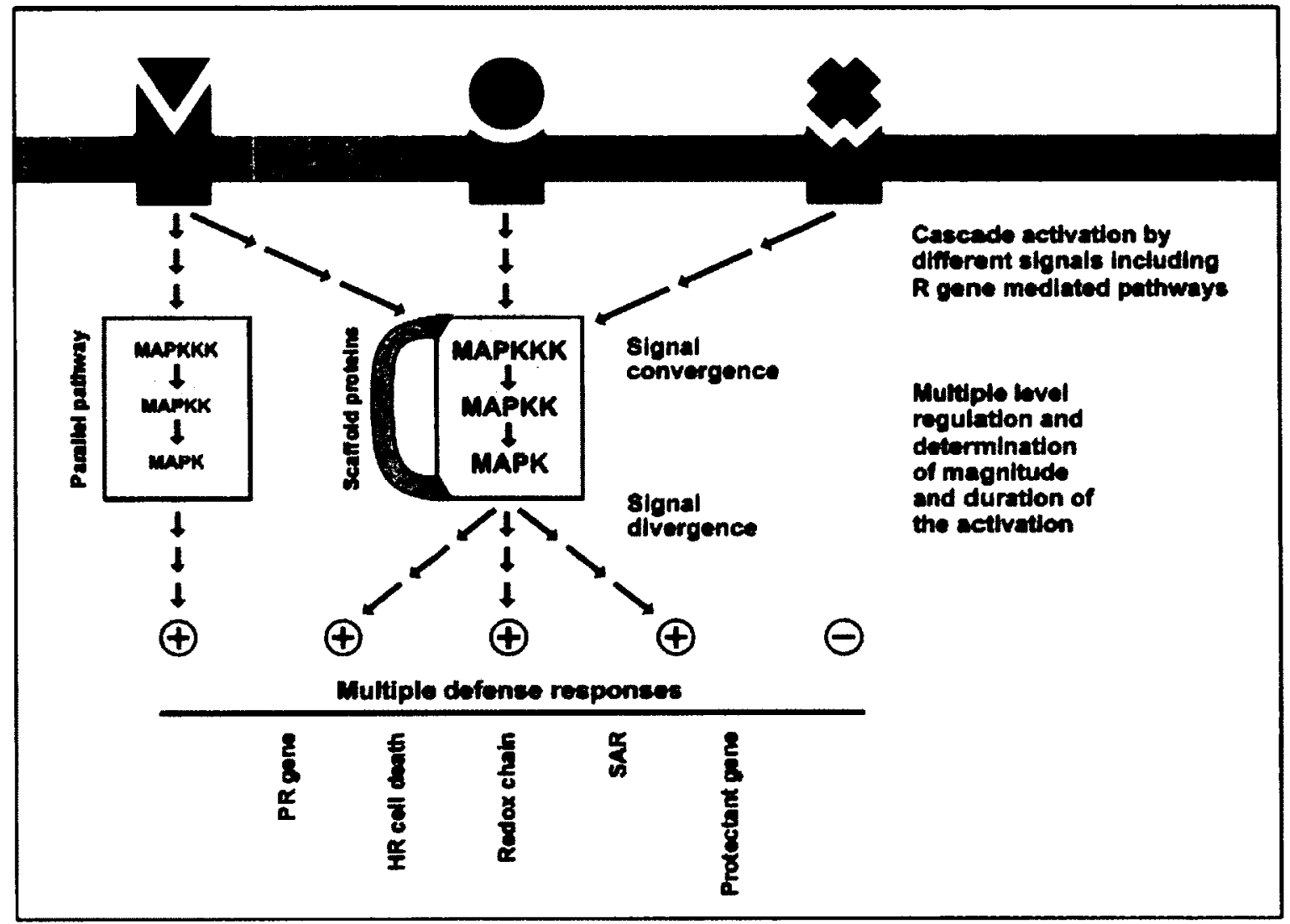

Figure 1.1: Representation of mitogen-activated protein kinase signal transduction cascades. An extracellular signal is received by a membrane-located receptor. The MAP kinase module where MAPKKK activates MAPKK which in turn activates MAPK is activated by the receptor. This may take place through several intermediary steps and by different routes. The active mitogen activated protein kinase may activate other protein kinases, phosphorylate cytoskeletal components or translocate to the nucleus and activate transcription factors which give rise to the expression of specific genes (Xing et al., 2002). 


\subsection{Calreticulin}

Phosphorylation and/or dephosphorylation play major roles in many signal transduction pathways as previously indicated. In fact, posttranslational modifications can activate an array of defense mechanisms in terms of minutes (Xing et al., 2002). Thurston et al. (2005) showed that some proteins increased phosphorylation in the $\mathrm{TMEK}^{\mathrm{MUT}}$ transgenic tomato plant. These data were of soluble proteins from tomato leaves in the $\mathrm{pH} \mathrm{4-7.} \mathrm{Interestingly,} \mathrm{one} \mathrm{of} \mathrm{the} \mathrm{identified}$ proteins was calreticulin (CRT).

CRT is a protein that binds misfolded proteins and prevents them from leaving the ER to the Golgi apparatus (Machrill, 2011). Specifically CRT binds to oligosaccharides that have a glucose residue terminal and thus marks them for degradation. Usually during protein processing, these glucose residues are trimmed, however if the protein is misfolded the glucose residue is added so that $\mathrm{CRT}$ can bind to this protein and prevent it from leaving the ER marking it for degradation (Michalak et al., 2009).

CRT also binds to the secondary messenger calcium ion $\left(\mathrm{Ca}^{2+}\right)$ thus preventing it from being active. CRT is stored in compartments in the ER. Calcium is a secondary messenger that is involved in regulating many cellular processes like cell death. Calcium moves through gated channel protein found in the plasma membrane, ER and other organelles (Machrill, 2011). Therefore, constant variations in the concentration of calcium ions in the ER affect the activity of CRT, calnexin and other ER proteins (Michalak et al., 2002). Calnexin is similar to CRT in function but acts upon soluble proteins instead (Machrill, 2011). Figure 1.2 shows a schematic representation of both CRT and calnexin. 


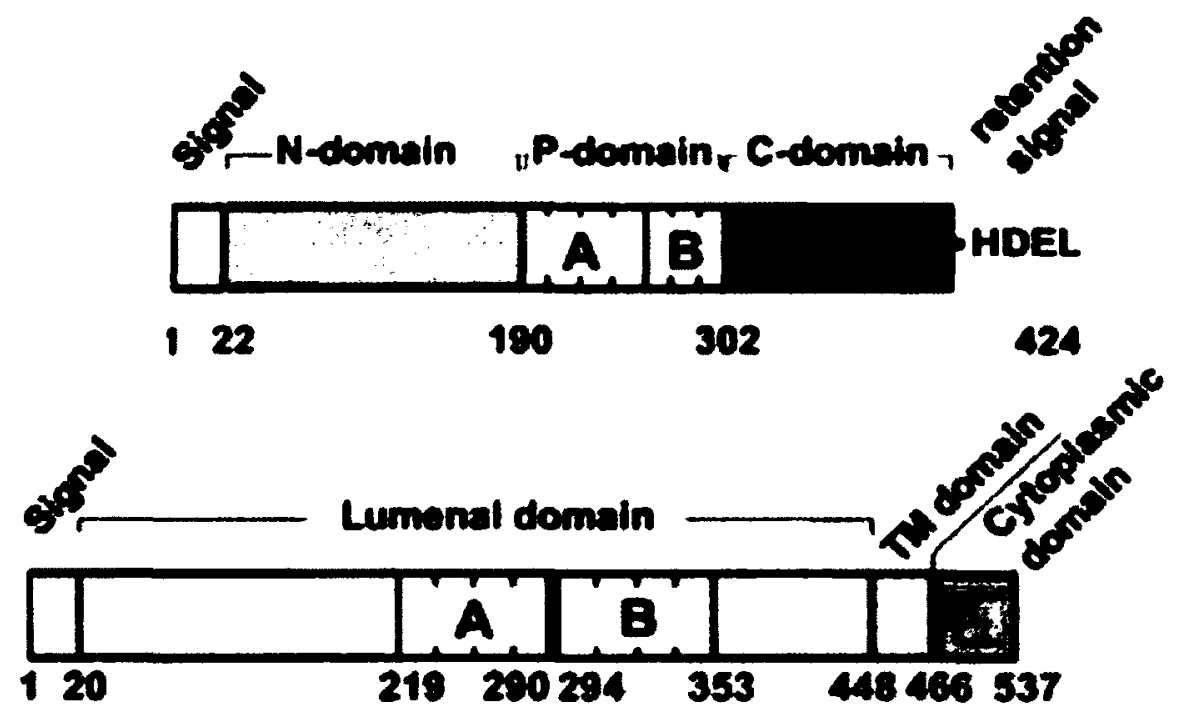

Figure 1.2: Diagram comparing the structure of both calreticulin and calnexin. Calreticulin (top) shows the typical structure comprising an N-domain, a P-domain consisting of A and B repeats, and a C-domain ending with a HDEL retention signal. In calnexin (bottom), a signal sequence is followed by the luminal domain including a cluster of $A$ and $B$ repeats, which is separated by a transmembrane (TM) domain from the cytoplasmic domain (modified from MüllerTaubenberger et al., 2001).

There are three domains in CRT. The N-domain is the most conserved domain. It is unique to CRT and is absent in calnexin. The P-domain is rich in proline. At this site, chaperone activity and oligosaccharide binding occur to both proteins CRT and calnexin. This domain also contains two sets of very similar three sequence repeats $\mathrm{A}$ and $\mathrm{B}$. The $\mathrm{C}$-domain is very important for the binding of the highly charged $\mathrm{Ca}^{2+}$ ions. This domain is terminated by the $\mathrm{C}$ terminal HDEL endoplasmic reticulum (ER) retrieval signal in plants. CRT also has an $\mathrm{N}$ terminal signal sequence which is processed at the same time as the translation stage of the protein sequence (cotranslationally) (Jung et al., 1993). 


\subsection{CRT and MAPK}

Since calcium ions are involved in both CRT and MAPK pathways, a relationship might be present between CRT and MAPK. According to Liu et al. (2006), calcium ions are involved in hypoxic pre-conditioning attenuates tissue injury. This implies that CRT also has a role in the regulation as it is a calcium-binding chaperone. However, Liu et al. (2006) also found that the expression of CRT was linked with an increase in the expression of p38 MAPK and a decrease in the expression of JNK phosphorylation. MAPKs can be categorized into three broad subfamilies: c-Jun NH2-terminal kinases (JNKs), p38 MAPKs, and ERKs (Schramek 2002). As such, this study related CRT to two types of MAPKs. In support to that, the authors found that the inhibition of p38 eliminated the up-regulation of CRT while inhibition of JNK had an opposite effect. This positive relation between p38 MAPK and CRT expression was also supported by another study (Wu et al. 2007).

\section{6. $\beta$-1, 3-glucanase}

The induction of pathogenesis-related (PR) proteins is provoked as a response to microbial pathogen infection in plants. Proteins of these groups displayed the most significant responses to fungal pathogens, and are most likely to contain pathogenesis related (PR)-genes whose transcription is up-regulated following pathogen infection (Levy et al., 2007).

$\beta-1,3$-glucanase is an enzyme involved in many physiological and developmental processes in higher plants. The extent as to how much this enzyme is expressed is controlled by plant hormones. This enzyme is a pathogenesis-related protein and belongs to the PR-2 group. Therefore, this enzyme is highly expressed as a response to plants being wounded or infected by fungal, bacterial, or viral pathogens (Wu et al., 2001). $\beta$-1,3-glucanase is involved in plant 
defense against fungal infection by hydrolyzing the structural component $\beta-1,3$-glucan in the fungal cell wall. This hydrolyzation causes the fungal cell wall to destabilize and in some cases releases immune elicitors associated with the cell wall that promote more defense responses (Doxey, 2007).

\subsection{Glutamine synthetase}

Glutamine synthetase is an enzyme used by plants in nitrogen metabolism. Glutamine synthetase plays an important role in assimilation for ammonia produced from nitrogen fixation, and nitrate or ammonia nutrition. Glutamine synthetase is found in several subcellular locations as well as tissues. However, the distribution of glutamine synthetase is thought to change as the tissues develop. An example would be the major function of glutamine synthetase in leaf senescence (Miflin and Habash, 2002).

\subsection{My project}

\subsubsection{CRT in MAPK pathway}

The main interest is to study the relationship between CRT and the ER in Solanum lycopersicum leaves, and the involvement of MAPK pathways. Both CRT and ER are involved in protein folding. CRT deals with misfolded proteins by binding to them and marking them for degradation so that only the properly folded proteins are allowed to move away from the ER (Michalak et al., 2009).

Previous work in the lab has indicated that phosphorylation level of CRT was enhanced when tomato tMEK2 (a MAPKK) was constitutively activated (Thurston et al., 2005). tMEK2 
transgenic line under the heat stress can phosphorylate CRT and the phosphorylation level of CRT is higher in the transgenic line than in the wild type (Thurston et al., 2005).

tMEK2 has been used as a model system in previous studies of MAPK pathways. Expressions in tomato, Arabidopsis and wheat have been shown to enhance the resistance to various plant pathogens. Previous proteomics analysis has identified some downstream proteins that were phosphorylated by tMEK2 in tomato (Thurston et al., 2005). Based on that, in this study we will further examine some of these proteins. This work is of vital importance in understanding how tMEK2 enhances disease resistance and stress tolerance and how CRT specifically fits into play. To do so, we intend to study CRT and its connection to MAPK pathway since CRT is involved in calcium ion binding rendering it inactive. Just like tMEK2, it is possible that several different pathways upstream affect CRT function as well.

\subsubsection{CRT and ERK inhibitor}

It is predicted that a downstream MAP kinase may mediate the phosphorylation of CRT. There are three classes of MAPK, p-38, c-Jun, and ERK (Jia et al., 2009). The activity of ERK sub-group of MAPK can be inhibited by ERK inhibitors. In order to test this relationship between CRT and ERK-type (MAPKs), ERK docking domain inhibitor (3-(2-Aminoethyl)-5-((4ethoxyphenyl) methylene)-2, 4-thiazolidinedione hydrochloride) was used. This ERK inhibitor is expected to interrupt the physical interaction of ERK-type MAPKs and their upstream MAPKKs. Although RT-PCR is at the transcriptional level there may be more CRT involved at the translational level or post-translational level. However, if the protein is inhibited then the cells will not produce this protein again so the transcriptional change will suffice to detect any difference. 


\subsubsection{FB1 and SA treatments}

The corn fungus Fusarium moniliforme produces a toxin called Fumonisin B1 (FB1). This toxin causes the induction of programmed cell death (PCD) in plants and animals (Asai et al., 2000). This fungal toxin acts as a competitive inhibitor of ceramide synthase thus causing a disruption in sphingolipid metabolism in eukaryotes (Desai et al., 2002). Ceramide is an important enzyme in sphingolipid biosynthesis (Abbas et al., 1994; Yoo et al., 1996; Stone et al., 2000). Sphingolipids are involved in a variety of cellular functions like differentiation, cell death and growth (Spiegel and Merrill, 1996; Stone et al., 2000). FB1 was used early on in the project but did not seem to have an effect on the expression of CRT at the transcriptional level. For that reason, the effect of other chemicals were tested and FB1 was omitted.

Salicylic acid (SA) is involved in plant growth and development, photosynthesis, transpiration, ion uptake, and transport. It is a phenolic phytohormone that induces specific changes in the anatomy of leaves and the structure of the chloroplast. Moreover, SA plays a critical role in plant defense when attacked by pathogens through the induction of pathogenesisrelated proteins (Chen et al., 2009). Therefore, the effect of SA on CRT expression was studied. Furthermore, if SA is believed to enhance the expression of CRT then it was of interest to examine what happens with CRT expression when tomato leaves were treated with SA combined with chemicals that are expected to reduce CRT expression.

\subsubsection{Unfolded protein response and CRT}

Interestingly, under stress conditions, lots of protein processing will change (Christensen et al., 2008). In fact, the synthesis of some proteins will slow down so the plant can spend more energy and resources to deal with the stress instead. Usually, the ER along with other proteins 
including CRT helps the proteins to fold correctly before moving away from the ER. Therefore, an ER stress will cause an unfolded protein response (UPR). This UPR can be induced by chemicals like tunicamycin (TM) and dithiothreitol (DTT) (Christensen et al., 2008). Under the stress, there will be unfolded protein problems and synthesis of proteins related to cell division and growth will slow down and instead the plant will deal with the stress by increasing the specific stress responsive proteins. This study showed if there is a relationship between the ER stress and CRT expression by examining whether or not CRT, as a chaperone, is involved in ER stress response (Christensen et al., 2008).

\subsubsection{CRT expression cloning for protein-protein interaction analysis}

In order to study protein-protein interaction by pull-down analysis, the CRT protein was expressed. CRT was cloned into pET14b vector. This vector is 4671 base pair long and has a multiple cloning site. The CRT target protein was expressed and optimized then detected by SDS-PAGE and Western blotting. CRT is expected to interact with other molecules involved in protein misfolding like BiP or SHD.

\subsubsection{Enzyme assays}

Enzyme assays were carried out to study their activities in response to different treatments. $\beta$-1, 3-glucanase (PR2) assay was examined. Because glucanase is a very important enzyme involved in pathogen cell wall degradation, its synthesis is of vital importance and requires energy for its levels to be maintained during plant defense responses. Pathogenesis will cause the synthesis of some proteins to slow down so the plant can spend more energy and resources to deal with the stress instead (Mazarei et al., 2007). When a stress is applied to a plant, all unnecessary energy consuming reactions are decreased in order for the plant to deal 
with the stress first. Consequently, it was expected that the stress response proteins like PR2 were to be expressed more (Xiao and Chye, 2011). This activity was tested in crude extracts from leaves that have been treated with SA, TM, or DTT. The glutamine synthetase assay was also carried out. Glutamine has several biochemical functions in the cell such as protein synthesis and nitrogen donation. Because the synthesis of glutamine is energy expensive and is more related to vegetative growth, its production was expected to decrease when a stress was applied (Aledo, 2004). Therefore the glutamine synthetase activity was also expected to decline. Glutamine synthetase activity was tested in leaves that have also been treated with SA, TM or DTT.

This project was carried out on the CRT tomato gene SGN-U578018. Another CRT tomato gene AK321700.1 was identified. Since only SGN-U578018 gene was successfully amplified, AK321700.1 gene was not studied and therefore all CRT mentioned in the text to follow are merely the SGN-U578018 gene unless otherwise indicated.

It is hoped that this work would produce new knowledge into diverse aspects of MAPK pathways to facilitate comprehensive and molecular understanding of the complex defense system. The discoveries will lay the ground for knowledge-based innovative strategies to reduce the impact of plant diseases. 


\section{Chapter II}

\section{Methods and Materials}

\subsection{Plant materials and growth conditions}

Tomato seeds (cv. Bonney Best) were obtained from Ritchie Feed \& Seed Inc. (Ottawa, Ontario). The seeds were surface sterilized for $2 \mathrm{~min}$ in $70 \%$ ethanol. The seeds were then soaked for $8 \mathrm{~min}$ in sterilization solution $(25 \%$ Bleach $\mathrm{v} / \mathrm{v}$ and $0.01 \%$ Triton X-100 v/v). Afterwards, the seeds were rinsed with autoclaved water 10 times and sowed directly in autoclaved Pro-mix BX soil (Ritchie Feed \& Seed Inc. Ottawa, Ontario). The seeds were then grown for $16 \mathrm{hr}$ at $22^{\circ} \mathrm{C}$ in the light and $8 \mathrm{hr}$ at $18^{\circ} \mathrm{C}$ in the dark in growth chambers (ENCONAIR Technologies Inc, Winnipeg, Manitoba).

\subsection{Treatments}

Different treatments were used on the leaves to investigate gene expression changes. In each treatment, three to four leaves were collected from four-week old plants and vacuum infiltrated with the corresponding chemical at indicated concentrations for $30 \mathrm{~min}$. The leaves were then placed on filter paper in Petri dishes containing the same treatment at the same concentration. Leaves were then photographed and collected at $0 \mathrm{hr}$ and $48 \mathrm{hr}$ incubation intervals in RNase-free Falcon tubes. Before collection, the $48 \mathrm{hr}$ treated leaves were returned to the same growth chamber for incubation. The samples were then snap-frozen in liquid nitrogen and stored at $-80^{\circ} \mathrm{C}$. Similarly, leaves were infiltrated in autoclaved water and served as the control at $0 \mathrm{hr}$ and $48 \mathrm{hr}$ incubation. The frozen samples were used for either protein or RNA extraction.

Table 2.1 shows the different treatments used and the corresponding concentrations. Fumonision B1 (FB1) was at 5 $\mu \mathrm{M}$, ERK docking domain inhibitor (3-(2-Aminoethyl)-5-((4ethoxyphenyl) methylene)-2, 4-thiazolidinedione hydrochloride) (ERKi) was at $250 \mu \mathrm{M}$, salicylic 
acid (SA) at $100 \mu \mathrm{M}$, tunicamycin (TM) at $5 \mu \mathrm{g} / \mathrm{mL}$ and dithiothreitol (DTT) at $1 \mathrm{mM}$. Even when SA was combined with other treatments (e.g. SA + ERKi, SA + TM etc.), the same concentrations were applied.

Table 2.1: The different treatments used along with their corresponding concentrations.

\begin{tabular}{|c|c|}
\hline Treatment & Concentration \\
\hline FB1 & $5 \mu \mathrm{M}$ \\
\hline ERKi & $250 \mu \mathrm{M}$ \\
\hline SA & $100 \mu \mathrm{M}$ \\
\hline TM & $5 \mu \mathrm{g} / \mathrm{mL}$ \\
\hline DTT & $1 \mathrm{mM}$ \\
\hline
\end{tabular}

\subsection{RNA extraction}

Using TRIzol Reagent kit (Life Technologies, USA) and according to the manufacturer's protocol, total RNA was extracted from tomato leaves. About $0.1 \mathrm{~g}$ of leaves was grinded in liquid nitrogen to a powder form. These leaf tissues were then homogenized in $1 \mathrm{~mL}$ TRIzol and incubated at room temperature $(\mathrm{RT})$ for $5 \mathrm{~min}$ to permit the complete dissociation of nucleoprotein complexes. $200 \mu \mathrm{L}$ chloroform was then added and mixed by hand for $15 \mathrm{~min}$ and the sample was incubated for $3 \mathrm{~min}$ at $\mathrm{RT}$. The sample was then centrifuged at $4^{\circ} \mathrm{C}$ in $5804 \mathrm{R}$ Eppendorf centrifuge for $15 \mathrm{~min}$ at $12,000 \mathrm{~g}$. Three separate layers formed as a result: the lower layer containing the phenol-chloroform phase, an interphase and a colorless upper aqueous phase. This upper colorless layer contained the RNA and was therefore transferred to a new tube and $500 \mu \mathrm{L}$ isopropyl alcohol was added. The sample was then incubated for $10 \mathrm{~min}$ at $\mathrm{RT}$ and centrifuged at $4^{\circ} \mathrm{C}$ for $10 \mathrm{~min}$ at $12,000 \mathrm{~g}$. The supernatant was removed and the pellet was the RNA. This pellet was washed with $500 \mu \mathrm{L} 75 \%$ ethanol and vortexed for proper mixing. The sample was then centrifuged at $4^{\circ} \mathrm{C}$ for $5 \mathrm{~min}$ at $7,500 \mathrm{~g}$. Ethanol was then removed and the pellet was air-dried for $10 \mathrm{~min}$ at RT. The pellet was then dissolved in $25 \mu \mathrm{L}$ RNase-free water and the sample was incubated at $60^{\circ} \mathrm{C}$ for $10 \mathrm{~min}$ in a water bath. RNA concentration was measured using 
Nanodrop ND-1000 spectrophotometer (Thermo Fisher Scientific, USA). The sample was stored at $-20^{\circ} \mathrm{C}$.

\subsection{DNase I treatment}

Following TRIzol extraction, genomic DNA contamination was eliminated using Deoxyribonuclease I kit (amplification grade, Life Technologies, USA). $1 \mu \mathrm{L}$ 10X DNase I reaction buffer (100mM Tris-HCL (pH7.5), $25 \mathrm{mM} \mathrm{MgCl}_{2}, 5 \mathrm{mM} \mathrm{CaCl}_{2}$ ) was added to $1 \mu \mathrm{g}$ RNA sample in an RNase-free $0.5 \mathrm{~mL}$ microcentrifuge tube on ice. Then $1 \mu \mathrm{L}$ of $1 \mathrm{U} / \mu \mathrm{L}$ DNase I was added and the volume was brought up to $10 \mu \mathrm{L}$ with DEPC-treated water. The sample was incubated at RT for $15 \mathrm{~min}$ and then on ice for $2 \mathrm{~min}$. $1 \mu \mathrm{L}$ of $25 \mathrm{mM}$ EDTA was then added to the reaction to inactivate DNase $\mathrm{I}$ and the sample was heated at $65^{\circ} \mathrm{C}$ for $10 \mathrm{~min}$ and stored at $-20^{\circ} \mathrm{C}$. RNA concentration was measured using Nanodrop ND-1000 spectrophotometer.

\subsection{Cloned AMV first-strand cDNA synthesis}

cDNA synthesis was carried out using Cloned AMV First-Strand cDNA Synthesis Kit (Life Technologies, Carlsbad, CA, USA) according to the manufacturer's protocol. $1 \mu \mathrm{L}$ of $50 \mu \mathrm{M}$ Oligo (dT) $)_{20}$ was added to $1 \mu \mathrm{g}$ RNA sample along with $2 \mu \mathrm{L}$ of $10 \mathrm{mM}$ dNTP mix. The mixture was brought up to $12 \mu \mathrm{L}$ with DEPC-treated water. The mixture was incubated at $65^{\circ} \mathrm{C}$ for $5 \mathrm{~min}$ and then placed on ice for $2 \mathrm{~min}$. Next, $4 \mu \mathrm{L}$ of $5 \mathrm{X}$ cDNA synthesis buffers ( $250 \mathrm{mM}$ Tris acetate (pH8.4), $375 \mathrm{mM}$ potassium acetate, $40 \mathrm{mM}$ magnesium acetate, stabilizer, $20 \mu \mathrm{g} / \mathrm{mL}$ bovine serum albumin (BSA)) was added to the tube along with $1 \mu \mathrm{L}$ of $0.1 \mathrm{M}$ DTT, $1 \mu \mathrm{L}$ of RNaseOUT $(40 \mathrm{U} / \mu \mathrm{L}), 1.5 \mu \mathrm{L}$ of DEPC-treated water and $0.5 \mu \mathrm{L}$ of cloned AMV RT $(15 \mathrm{U} / \mu \mathrm{L})$. The reaction was then heated for $48 \mathrm{~min}$ at $48^{\circ} \mathrm{C}$ and then for $5 \mathrm{~min}$ at $85^{\circ} \mathrm{C}$ in a thermal cycle and stored at $-20^{\circ} \mathrm{C}$. DNA concentration was measured using Nanodrop ND-1000 spectrophotometer (Thermo Fisher Scientific, USA). 


\subsection{Reverse transcriptase polymerase chain reaction (RT-PCR)}

All samples were diluted to $500 \mathrm{ng} / \mu \mathrm{L}$. For example, $\mathrm{H}_{2} \mathrm{O}(0 \mathrm{hr})$ of batch 1 has a concentration of $1862.1 \mathrm{ng} / \mu \mathrm{L}$ and $24 \mu \mathrm{L}$ were available. Therefore:

$$
\begin{gathered}
\mathrm{C}_{1} \mathrm{~V}_{1}=\mathrm{C}_{2} \mathrm{~V}_{2} \\
(1862.1 \mathrm{ng} / \mu \mathrm{L})(24 \mu \mathrm{L})=(500 \mathrm{ng} / \mu \mathrm{L})\left(\mathrm{V}_{2}\right) \\
\mathrm{V}_{2}=89.38 \mu \mathrm{L}
\end{gathered}
$$

So $74.38 \mu \mathrm{L}$ of DEPC water were added to $\mathrm{H}_{2} \mathrm{O}(0 \mathrm{hr})$ cDNA for a final concentration of $500 \mathrm{ng} / \mu \mathrm{L}$.

Reverse transcriptase PCR was performed using the actin gene as a standard control to obtain bands of similar intensity within the same batch. This was followed by RT-PCR using CRT primers to see how each treatment affected the expression of the gene. $20 \mu \mathrm{L}$ reactions were carried out using Taq DNA polymerase (Life Technologies, USA). When applicable, the negative control was prepared by adding DEPC water and no DNA template.

\subsubsection{Actin RT-PCR}

The primers used for actin RT-PCR were 5'TGGCATCATACTTTCTACAATG3' forward primer and 5'CTAATATCCACGTCACATTTCAT3' reverse primer. RT-PCR amplification started with initial denaturation at $94^{\circ} \mathrm{C}$ for $3 \mathrm{~min}$. This was followed by a 28 -cycle of denaturation at $94^{\circ} \mathrm{C}$ for $1 \mathrm{~min}$ then primer annealing at $60.2^{\circ} \mathrm{C}$ for $1 \mathrm{~min}$ and then extension at $72^{\circ} \mathrm{C}$ for $45 \mathrm{sec}$. Subsequently, extending was carried out at $72^{\circ} \mathrm{C}$ for $10 \mathrm{~min}$. The size of the actin gene was around $600 \mathrm{bp}$. 


\subsubsection{CRT RT-PCR}

The primers used for CRT RT-PCR were 5'CATATGATGCTAGTAGTCGCC3' forward primer and 5'CTCGAGTTATGAATCAGCCTC 3' reverse primer. These primers were designed with the forward primer containing Ncol restriction endonuclease cut site and the reverse primer containing XhoI restriction endonuclease cut site. RT-PCR with the two primers will amplify full size CRT. Similarly, RT-PCR was performed to amplify CRT gene by first denaturing at $94^{\circ} \mathrm{C}$ for $3 \mathrm{~min}$. Also a 28 -cycle was followed by denaturation at $94^{\circ} \mathrm{C}$ for $1 \mathrm{~min}$ then primer annealing at $55.5^{\circ} \mathrm{C}$ for $1 \mathrm{~min}$ and extension at $72^{\circ} \mathrm{C}$ for $1.5 \mathrm{~min}$. Finally, extending occurred at $72^{\circ} \mathrm{C}$ for $10 \mathrm{~min}$. Only LeCRT2 was successfully amplified and therefore all the following experiments were carried on LeCRT2 gene only. To make things easier, this gene will be referred to as CRT. The size of CRT gene was $1143 \mathrm{bp}$.

\subsection{Cloning CRT gene into pET14b vector}

\subsubsection{Producing the Blunt-End PCR products}

cDNA of $0 \mathrm{hr}$ water treatment of $2390.4 \mathrm{ng} / \mu \mathrm{L}$ concentration was used in order to clone our target CRT gene. CRT was amplified using high-fidelity Platinum $\otimes P f x D N A$ proofreading Polymerase (Life Technologies, USA). The CRT primers used in our experiments were designed to contain restriction endonuclease cleavage sites so that the PCR products can be inserted into various plasmids' multiple cloning sites. A $50 \mu \mathrm{L}$ reaction was prepared and PCR was carried out by denaturing at $94^{\circ} \mathrm{C}$ for $5 \mathrm{~min}$. A 35 cycle was followed by denaturation at $94^{\circ} \mathrm{C}$ for $15 \mathrm{sec}$ then primer annealing at $55.5^{\circ} \mathrm{C}$ for $30 \mathrm{sec}$ and extension at $68^{\circ} \mathrm{C}$ for $1.5 \mathrm{~min}$. Finally, extending occurred at $68^{\circ} \mathrm{C}$ for $10 \mathrm{~min}$. The reaction was run on an agarose gel electrophoresis to confirm the size and then gene cleaned using Wizard $囚$ Plus Minipreps DNA Purification System 
(Promega Corp., USA). The same was done to the control template gene provided by the zero blunt TOPO cloning kit for sequencing.

\subsubsection{Cloning into TOPO vector}

Zero Blunt TOPO is a five minute one step cloning strategy for direct insertion of bluntend PCR products into a plasmid vector for sequencing. This vector functions well in both One Shot Chemically and Electrocomp Competent cells. However, for our purposes, One Shot Chemically Competent cells (Mach1 ${ }^{\mathrm{TM}}-\mathrm{T} 1^{\mathrm{R}}$ cells and BL21 cells) were used. Note that TOPO is 3.9 $\mathrm{Kb}$ in length (Life Technologies, 2006).

TA cloning TOPO is provided as a linear vector with 3'-thymidine overhangs thus allowing for the efficient ligation of the PCR inserts. TOPO is also supplied with Topoisomerase I, which is covalently bound to the vector (referred to as "activated" vector). This enzyme is extracted from Vaccinia virus and binds to the duplex DNA at specific sites (Life Technologies, 2006).

The Mach $1^{\mathrm{TM}} \mathrm{T} 1$ Phage-Resistant $\left(\mathrm{T} 1^{\mathrm{R}}\right)$ is a chemically competent Escherichia coli strain dominantly used for cloning. This strain has the fastest growing rate and its optical density measured at $600 \mathrm{~nm}$ is doubled in only $50 \mathrm{~min}$ as opposed to $74 \mathrm{~min}$ for other strains used in cloning. Consequently, Mach $1^{\mathrm{TM}}$ colonies may be observed after eight hours of plating therefore saving lots of time.

The TOPO cloning reaction was prepared in order to directly insert the blunt-end PCR product $(\mathrm{CRT})$ into the plasmid vector for sequencing. This reaction was performed as indicated in Table 2.2 . 
Table 2.2: The relative solutions and volumes $(\mu \mathrm{L})$ used to perform the TOPO cloning reaction in which CRT gene was inserted into the plasmid vector.

\begin{tabular}{|c|c|}
\hline Reagent & Volume $(\mu \mathrm{L})$ \\
\hline Fresh PCR product (CRT2) & 4 \\
\hline Salt solution & 1 \\
\hline pCR 4Blunt-TOPO & 1 \\
\hline Final volume & 6 \\
\hline
\end{tabular}

As in the CRT insert, the TOPO reactions were performed for the control reaction prepared above as well as another control expressing the vector only (Table 2.3).

Table 2.3: The relative solutions and volumes $(\mu \mathrm{L})$ used to perform the control TOPO cloning reaction.

\begin{tabular}{|c|c|c|}
\hline Reagent & Vector Only $(\mu \mathrm{L})$ & $\begin{array}{c}\text { Vector + Control PCR } \\
\text { Insert }(\mu \mathrm{L})\end{array}$ \\
\hline Control PCR Product & --- & 1 \\
\hline Sterile Water & 4 & 3 \\
\hline Salt Solution & 1 & 1 \\
\hline pCR 4Blunt-TOPO & 1 & 6 \\
\hline Final Volume & 6 & \\
\hline
\end{tabular}

The three reactions were mixed gently and incubated for $5 \mathrm{~min}$ at room temperature and then on ice. Each reaction was then undergone one shot chemical transformation. This was 
performed by adding $2 \mu \mathrm{L}$ of the TOPO cloning reaction into separate $50 \mu \mathrm{L}$ Mach $1^{\mathrm{TM}}-\mathrm{T} 1^{\mathrm{R}}$ cells. The cells were incubated for $15 \mathrm{~min}$ and then heat shocked for exactly 30 seconds at $42^{\circ} \mathrm{C}$ without shaking. The tubes were then immediately transferred to ice. $250 \mu \mathrm{L}$ of room temperature S.O.C. medium were added to each tube which were then horizontally shaken at $200 \mathrm{rpm}$ at $37^{\circ} \mathrm{C}$ for 1 hour. Then $15 \mu \mathrm{L}$ and $45 \mu \mathrm{L}$ from each transformation were spread on pre-warmed $50 \mu \mathrm{g} / \mathrm{mL}$ kanamycin selective plates. Because $15 \mu \mathrm{L}$ is a small volume, this amount was added to a pool of $20 \mu \mathrm{L}$ S.O.C. medium on the plate for better spreading. All the plates were incubated overnight at $37^{\circ} \mathrm{C}$ for the colonies to grow.

Nine colonies from the plates containing the CRT PCR product of interest inserted in the TOPO vector were picked for inoculation. The colonies picked were the ones mostly isolated and relatively large. The 18 total colonies picked were inoculated in $4 \mathrm{~mL} \mathrm{LB}$ medium containing $50 \mu \mathrm{g} / \mathrm{mL}$ kanamycin antibiotic and left to grow overnight on a shaker at $200 \mathrm{rpm}$ and $37^{\circ} \mathrm{C}$. Plasmid preparation was performed according to Wizard® Plus SV Minipreps DNA Purification Systems protocol. PCR was then performed to check for the insert recovery. This PCR was performed in the same way as amplifying CRT gene using Taq DNA polymerase (Life Technologies, USA). The amount of plasmid used was $4 \mu \mathrm{L}$ for a total reaction of $20 \mu \mathrm{L}$. The concentrations of all samples were measured using Nanodrop.

\subsubsection{Digesting the insert and vector to produce the sticky (cohesive) ends}

Double digestion was performed using NdeI and Xhol restriction enzymes. Both enzymes are $100 \%$ active in buffer $\mathrm{H}\left(\mathrm{pH} 7.5,90 \mathrm{mM}\right.$ Tris- $\mathrm{HCl}, 10 \mathrm{mM} \mathrm{MgCl}_{2}$, and $\left.50 \mathrm{mM} \mathrm{NaCl}\right)$. 


\subsubsection{Double digestion of CRT insert}

CRT insert $(175.1 \mathrm{ng} / \mu \mathrm{L})$ was used. $3 \mu \mathrm{g}(17.2 \mu \mathrm{L})$ of the sample was mixed with $3 \mu \mathrm{L}$ buffer $\mathrm{H}, 1 \mu \mathrm{L}$ NdeI restriction enzyme and $1 \mu \mathrm{L}$ Xhol restriction enzyme. The volume was brought up to a total of $30 \mu \mathrm{L}$ with DEPC water and digested for $3 \mathrm{hr}$ at $37^{\circ} \mathrm{C}$. The sample was then loaded on a $1 \%$ gel along with its uncut sample and run at 100 volts for $1 \mathrm{hr}$. CRT was then cut out of the gel and gene cleaned using Wizard $\bigotimes^{8}$ Plus Minipreps DNA Purification System (Promega Corp., USA). The concentration was measured using Nanodrop.

\subsubsection{Double digestion of $\mathrm{pET} 14 \mathrm{~b}$ vector}

$3 \mu \mathrm{g}$ pET14b vector was directly double digested without being transformed in any cells. $6 \mu \mathrm{L}$ of $0.5 \mu \mathrm{g} / \mu \mathrm{L}$ pET14b vector was digested in $3 \mu \mathrm{L}$ buffer $\mathrm{H}$ and $19 \mu \mathrm{L}$ DEPC water with $1 \mu \mathrm{L}$ Ndel restriction enzyme at $37^{\circ} \mathrm{C}$ for $2 \mathrm{hr}$ (Figure 2.1 ). $3 \mu \mathrm{L}$ of the sample was run on a $0.8 \%$ gel to check the size. Then the reaction was digested with $1 \mu \mathrm{L}$ Xhol restriction enzyme for $2 \mathrm{hr}$ at $37^{\circ} \mathrm{C}$ and $3 \mu \mathrm{L}$ of the sample was run on a $0.8 \%$ gel. Afterwards, $0.27 \mu \mathrm{L}$ of $20 \mathrm{U} / \mu \mathrm{L}$ CIAP was added to the mixture and the reaction was incubated at $37^{\circ} \mathrm{C}$ for $30 \mathrm{~min}$. The whole reaction was then loaded on a $1 \%$ gel and run at 100 volts for $1 \mathrm{hr}$. pET14b sample was then gene cleaned using Wizard $($ Plus Minipreps DNA Purification System (Promega Corp., USA) and the concentration was measured using Nanodrop. 


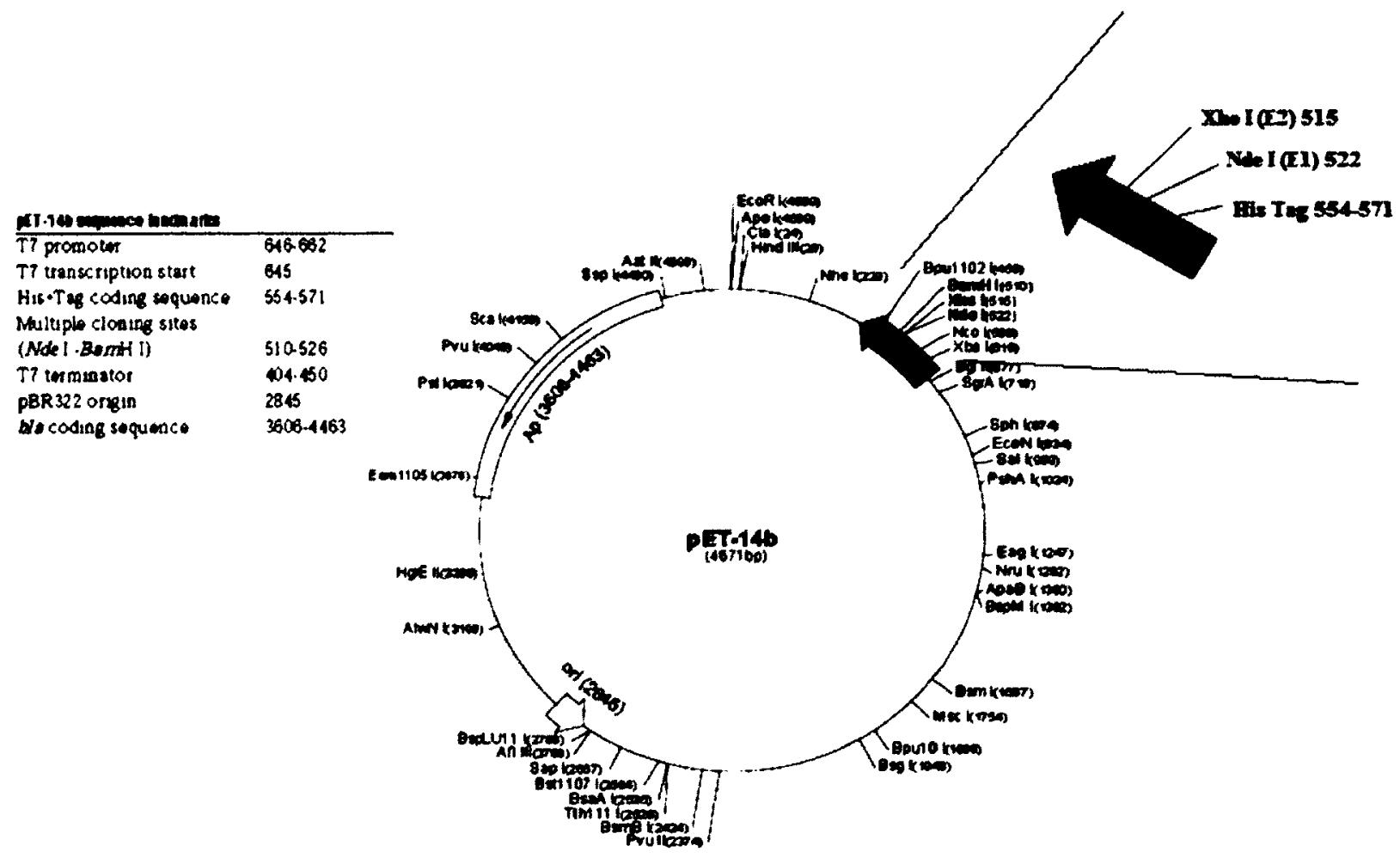

Figure 2.1: pET14b vector map with restriction sites and characteristics showing an enlarged representation of the positions of the used digestion enzymes (E1 and E2) as well as the His tag (Novagen, 2005).

\subsubsection{Ligating the double digested CRT insert and pET14b vector}

Ligation 1 (1:3 vector to insert ratio) was prepared by mixing $2.7 \mu \mathrm{L}$ pET14b vector, $5.3 \mu \mathrm{L}$ CRT insert, $1.5 \mu \mathrm{L}$ of $5 \mathrm{X}$ ligase buffer $(250 \mathrm{mM}$ Tris- $\mathrm{HCl}(\mathrm{pH} 7.6), 50 \mathrm{mM} \mathrm{MgCl} 2,5 \mathrm{mM}$ ATP, 5mM DTT, and 25\% (w/v) polyethylene glycol-8000) and $0.5 \mu \mathrm{L}$ T4 DNA ligase enzyme for a total reaction of $10 \mu \mathrm{L}$.

Ligation 2 (1:1 vector to insert ratio) was prepared by mixing $4.8 \mu \mathrm{L}$ pET14b vector, $3.2 \mu \mathrm{L}$ CRT insert, $1.5 \mu \mathrm{L}$ of $5 X$ ligase buffer $(250 \mathrm{mM}$ Tris- $\mathrm{HCl}(\mathrm{pH} 7.6), 50 \mathrm{mM} \mathrm{MgCl}, 5 \mathrm{mM}$ 
ATP, 5mM DTT, and 25\% (w/v) polyethylene glycol-8000) and $0.5 \mu \mathrm{L}$ T4 DNA ligase enzyme for a total reaction of $10 \mu \mathrm{L}$.

Control 1 had only the vector and no insert while control 2 had only the insert and no vector. DEPC water was added to account for a total volume of $10 \mu \mathrm{L}$.

All the reactions were left at $4^{\circ} \mathrm{C}$ overnight. The reactions were then transformed into $20 \mu \mathrm{L}$ BL21 cells and platted on LB plates containing $100 \mu \mathrm{g} / \mathrm{mL}$ ampicillin antibiotic at $15 \mu \mathrm{L}$ and $150 \mu \mathrm{L}$ aliquots. BL21 cells are generally employed as host setting for protein expression. The plates were left at $37^{\circ} \mathrm{C}$ overnight for colonies to grow.

\subsubsection{Checking for the correct orientation}

Typically the insert would be ligated in the vector in the correct orientation, however that is not always the case since sometimes the insert ligates in the wrong orientations to the vector. In order to check if the insert was ligated in the correct orientation, two tests were conducted. 10 colonies of each ligation were picked for plasmid preparation and the concentration of each sample was measured via Nanodrop.

When using PCR to check for orientation, one primer from the vector is used and the other from the insert so that one primer serves as a forward primer while the other as a reverse in the vector + insert system. Consequently, the forward primer of pET14b provided by the kit and the forward primer of CRT insert were used and a band of $1.3 \mathrm{~Kb}$ was expected. PCR was carried out in the same conditions for CRT RT-PCR. Conversely, a negative reaction (wrong orientation) was set by using the forward primer of $\mathrm{pET} 14 \mathrm{~b}$ vector and the reverse primer of CRT insert giving several undefined bands. 
An alternative way to check for orientation is using a restriction enzyme that has one cutting site in each of the vector and insert. In this case, NcoI restriction enzyme was used. NcoI enzyme cuts at position 580 in the pET14b vector and at position 787 in the CRT insert. Five samples $(9,11,16,18$ and 19) with the highest concentrations were selected to undergo a single digestion with Ncol restriction enzyme by mixing $0.5 \mu \mathrm{g}$ of the sample with $2 \mu \mathrm{L}$ REact $3(50 \mathrm{mM}$ Tris- $\mathrm{HCl}(\mathrm{pH} 8.0), 10 \mathrm{mM} \mathrm{MgCl}_{2}$, and $\left.100 \mathrm{mM} \mathrm{NaCl}\right), 1 \mu \mathrm{L}$ Ncol restriction enzyme and DEPC water up to $20 \mu \mathrm{L}$ reaction total. The reactions were incubated at $37^{\circ} \mathrm{C}$ for $4 \mathrm{hr}$ then run on a $0.8 \%$ gel at 100 volts for $1 \mathrm{hr}$. Together the vector and insert are $5814 \mathrm{bps}$ in size taking into consideration the restriction sites. If the ligation were in the correct orientation, a small band of $850 \mathrm{bps}$ and a larger one of $4964 \mathrm{bps}$ in size were expected to be obtained. However if the ligation were in the wrong orientation, a small band of $416 \mathrm{bps}$ and a larger one of $5398 \mathrm{bps}$ in size were expected to be obtained.

\subsection{Expressing the target gene}

Escherichia coli are prokaryotes that are easily grown with simple and easily manipulated or duplicated genetics through metagenics. This makes these bacteria excellent models used in microbiology and biotechnology especially in creating recombinant DNA by plasmids and restriction enzymes.

There are several reasons as to why $E$. coli are widely used especially in recombinant DNA. Some of these reasons include but are not limited to genetic simplicity in terms of small genome size that has been completely sequenced, fast growth rate, ability to host foreign DNA and safety use. 
BL21-CodonPlus (DE3)-RIPL competent cells are able to produce an increased supply of rare E. coli tRNAs that correspond to codons used more frequently by other organisms. This novel host contains extra copies of $\arg U$, ileW, leuY and proL tRNA that recognize arginine, isoleucine, leucine and proline codons respectively. Therefore, this strain is used to overcome problems due to codon bias.

\subsubsection{Expression host transformation}

Sample 19 of $42.0 \mathrm{ng} / \mu \mathrm{L}$ concentration was used in order to express the target gene. $2 \mu \mathrm{L}$ of 1:10 dilution of XL10-Gold $\beta$-mercaptoethanol mix was added to $100 \mu \mathrm{L}$ of BL21-CodonPlus (DE3)-RIPL competent cells. The contents were swirled gently and the cells were incubated on ice for $10 \mathrm{~min}$ swirling gently every $2 \mathrm{~min} .1 \mu \mathrm{L}$ of sample 19 was added and the contents were swirled gently. The reaction was incubated on ice for $30 \mathrm{~min}$. The transformation was then heatpulsed in a $42^{\circ} \mathrm{C}$ water bath for $20 \mathrm{sec}$. The reaction was then incubated on ice for $2 \mathrm{~min}$ and $0.9 \mathrm{~mL}$ of preheated $\left(\right.$ at $42^{\circ} \mathrm{C}$ ) S.O.C. medium was added. The transformation was incubated at $37^{\circ} \mathrm{C}$ for $1 \mathrm{hr}$ with shaking at $200 \mathrm{rpm} .150 \mu \mathrm{L}$ and $200 \mu \mathrm{L}$ of the cells were transformed on LB agar plates containing $30 \mu \mathrm{g} / \mathrm{mL}$ chloramphenicol and $100 \mu \mathrm{g} / \mathrm{mL}$ carbenicillin antibiotic. The plates were left overnight at $37^{\circ} \mathrm{C}$ for colonies to grow.

\subsubsection{Induction of $\lambda \mathrm{DE} 3$ lysogens with IPTG}

A single colony was picked from the $200 \mu \mathrm{L}$ plate and inoculated in $3 \mathrm{~mL} \mathrm{LB}$ containing $30 \mu \mathrm{g} / \mathrm{mL}$ chloramphenicol and $100 \mu \mathrm{g} / \mathrm{mL}$ carbenicillin antibiotics and $1 \%$ glucose $(\mathrm{pH} 8.2)$ to reduce basal expression levels. The sample was incubated at $37^{\circ} \mathrm{C}$ overnight. The next day, $1 \mathrm{~mL}$ of the culture was added to $100 \mathrm{~mL}$ LB medium containing $30 \mu \mathrm{g} / \mathrm{mL}$ chloramphenicol and $100 \mu \mathrm{g} / \mathrm{mL}$ carbenicillin antibiotics in a $500 \mathrm{~mL}$ Erlenmeyer flask $(20 \%$ of the total flask volume 
for good aeration). The culture was left to shake at $37^{\circ} \mathrm{C}$ for $3 \mathrm{hr}$ till $\mathrm{OD}_{600}$ was between 0.5-1.0. The culture was then cooled to $18^{\circ} \mathrm{C}$ by placing on ice for $30 \mathrm{~min}$ and divided into two $50 \mathrm{~mL}$ samples in two separate $250 \mathrm{~mL}$ Erlenmeyer flasks.

IPTG was added to one of the $50 \mathrm{~mL}$ cultures by adding $200 \mu \mathrm{L}$ of $100 \mathrm{mM}$ IPTG stock for a final concentration of $0.4 \mathrm{mM}$. This served as the induced culture while the other culture was used as the uninduced control. The cultures were left to shake overnight at $18^{\circ} \mathrm{C}$ at $225 \mathrm{rpm}$

\subsubsection{Determination of the culture $\mathrm{OD}_{600}$ at harvest}

After induction and just before harvest, the culture was shaken well to ensure a homogeneous suspension. LB medium with $30 \mu \mathrm{g} / \mathrm{mL}$ chloramphenicol and $100 \mu \mathrm{g} / \mathrm{mL}$ carbenicillin antibiotics was used as a blank. $0.5 \mathrm{~mL}$ of each of the induced and the uninduced cultures were removed and dilutions were made until $\mathrm{OD}_{600}$ was between 0.1 and 0.8 . A $5 \mathrm{X}$ dilution factor was prepared for the induced culture and 8.2X dilution for the uninduced cultures to get an $\mathrm{OD}_{600}$ reading between 0.1 and 0.8 for each culture.

\subsection{Target protein verification}

To facilitate verification, a small-scale analysis of total cell protein fraction, medium fraction and soluble cytoplasm fraction were examined.

\subsubsection{Total cell protein (TCP) fraction}

Before harvesting the cells, $1 \mathrm{~mL}$ sample of each well-mixed culture (induced and uninduced) were centrifuged at $10,000 \mathrm{~g}$ for $1 \mathrm{~min}$. The supernatant was removed and discarded and the pellets were allowed to drain by inversion tapping the excess medium onto a paper towel. Each pellet was resuspended completely by mixing in $100 \mu \mathrm{L}$ of $1 \mathrm{X}$ phosphate buffered saline 
(PBS) $\left(8 \mathrm{~g} / \mathrm{L} \mathrm{NaCl}, 0.2 \mathrm{~g} / \mathrm{L} \mathrm{KCl}, 1.44 \mathrm{~g} / \mathrm{L} \mathrm{Na} \mathrm{NPO}_{4}\right.$ and $\left.0.2 \mathrm{~g} / \mathrm{L} \mathrm{KH}_{2} \mathrm{KO}_{4}, \mathrm{pH} 7.4\right)$ giving a concentration factor of $10 \mathrm{X} .100 \mu \mathrm{L} 4 \mathrm{X}$ SDS sample buffer $(0.25 \mathrm{M}$ Tris $\mathrm{HCl} \mathrm{pH} 6.8,8 \% \mathrm{w} / \mathrm{v}$ SDS, $30 \% \mathrm{v} / \mathrm{v}$ glycerol, $0.02 \% \mathrm{w} / \mathrm{v}$ bromophenol blue, and $10 \% \mathrm{v} / \mathrm{v} \beta$-mercaptoethanol) was added to each tube and the samples were passed through a 27-gauge needle several times to reduce viscosity. The samples were then immediately heated for $3 \mathrm{~min}$ at $85^{\circ} \mathrm{C}$ to denature the proteins and stored at $-20^{\circ} \mathrm{C}$ for SDS-PAGE analysis.

\subsubsection{Medium fraction (MF)}

$40 \mathrm{~mL}$ of each culture were added in a pre-weighed tube and the cells were harvested by centrifugation at $10,000 \mathrm{~g}$ for $10 \mathrm{~min}$ at $4^{\circ} \mathrm{C} .1 \mathrm{~mL}$ of the supernatant from each culture was carefully transferred to a microcentrifuge tube without moving any cell pellets. The cell pellets were saved on ice for later use in soluble cytoplasmic fraction. The rest of the supernatant was discarded. The $1 \mathrm{~mL}$ medium was then concentrated by $100 \%(\mathrm{w} / \mathrm{v})$ trichloroacetic acid precipitation (TCA). $100 \mu \mathrm{L}$ of $100 \%(w / v)$ TCA was added to each $1 \mathrm{~mL}$ medium of each culture and vortexed for $15 \mathrm{sec}$. The tubes were placed on ice for $15 \mathrm{~min}$. Both samples were then centrifuged at $14,000 \mathrm{~g}$ for $10 \mathrm{~min}$ and the supernatant was removed and discarded. Each pellet was washed twice with $100 \mu \mathrm{L}$ acetone by adding the acetone, mixing and then spinning for $5 \mathrm{~min}$ at $14,000 \mathrm{~g}$. The acetone was discarded and the pellets were allowed to air dry thoroughly for $1 \mathrm{hr}$. $100 \mu \mathrm{L} 1 \mathrm{X}$ PBS was added as well as $100 \mu \mathrm{L}$ of $4 \mathrm{X}$ SDS sample buffer to each tube. The pellets were resuspended by vigorous vortexing and immediately each tube was heated for $3 \mathrm{~min}$ at $85^{\circ} \mathrm{C}$ to denature the proteins and then stored at $-20^{\circ} \mathrm{C}$ for SDS-PAGE analysis. 


\subsubsection{Soluble cytoplasmic fraction (SCF)}

This fraction was obtained using the BugBuster Master Mix and following the protocol provided with the reagent. The pellets harvested during medium fraction (MF) were used and their wet weights were determined after decanting. The cell pellet of each culture was resuspended in room temperature BugBuster Master Mix by pipetting using $5 \mathrm{~mL}$ reagent per gram of wet cell paste. The cell suspension of each culture was incubated on a shaking platform at a slow setting for $20 \mathrm{~min}$. The insoluble cell debris was removed by centrifugation at $16,000 \mathrm{~g}$ for $20 \mathrm{~min}$ at $4^{\circ} \mathrm{C}$. The supernatant of each culture was transferred to a fresh tube. $100 \mu \mathrm{L}$ of the supernatant of each culture was combined with $100 \mu \mathrm{L}$ of $4 \mathrm{X}$ SDS sample buffer in fresh tubes and the mixtures were immediately heated for $3 \mathrm{~min}$ at $85^{\circ} \mathrm{C}$ to denature the proteins. The samples were then stored at $-20^{\circ} \mathrm{C}$ for SDS-PAGE analysis.

\subsection{One-dimensional SDS- PAGE}

SDS-PAGE gel consists of two parts, the separating lower gel and the stacking upper gel. To prepare $15 \%$ of the separating gel, $7.2 \mathrm{~mL}$ water was mixed with $7.5 \mathrm{~mL}$ of $1.5 \mathrm{M}$ Tris- $\mathrm{HCl}$ (pH 8.8), $0.15 \mathrm{~mL}$ of $20 \% \mathrm{w} / \mathrm{v}$ SDS, and $15 \mathrm{~mL}$ of acrylamide/ bis-acrylamide $(30 \% / 0.8 \% \mathrm{w} / \mathrm{v})$. The solution was left to settle for $15 \mathrm{~min}$. Meanwhile, the plates were assembled and loaded into the gel casting apparatus. Afterwards, $0.15 \mathrm{~mL}$ of $10 \% \mathrm{w} / \mathrm{v}$ ammonium persulfate (APS) was added along with $0.02 \mathrm{~mL}$ of TEMED and the solution was swirled gently and quickly added into the space between the glass plates using a $1000 \mu \mathrm{L}$ pipette leaving about $1.5 \mathrm{~mL}$ space from the top of the plates. To ensure no bubble interference, the gel was overlaid with isobutyl alcohol and allowed to polymerize for one hour. 
As the lower gel was polymerizing, the upper stacking gel was prepared. $3.075 \mathrm{~mL}$ of water was added to $1.25 \mathrm{~mL}$ of $0.5 \mathrm{M}$ Tris-HCL (pH 6.8 ), $0.025 \mathrm{~mL}$ of $20 \% \mathrm{w} / \mathrm{v}$ SDS, and $0.67 \mathrm{~mL}$ of acrylamide/ bis-acrylamide $(30 \% / 0.8 \% \mathrm{w} / \mathrm{v})$. Once the lower gel had solidified, $0.025 \mathrm{~mL}$ of $10 \% \mathrm{w} / \mathrm{v}$ APS was added along with $0.005 \mathrm{~mL}$ of TEMED and the solution was swirled gently. The isobutyl alcohol was removed and the stacking gel was loaded instead in the gel stacking apparatus. The comb was then inserted and the gel was left to solidify for $1 \mathrm{hr}$.

The normalized volume of sample to load on a 10-well SDS-PAGE gel was calculated based on $\mathrm{OD}_{600}$ at harvest and sample concentration factor. BenchMarck pre-stained protein ladder (Invitrigen, USA) was loaded in one well to estimate the size and positions of sample proteins on the gel of induced and uninduced cultures. Electrophoretic separation was generally carried out in $1 \mathrm{X}$ running buffer (3.03g Tris base, $14.4 \mathrm{~g}$ glycine and $1 \mathrm{~g}$ SDS per liter, $\mathrm{pH} 8.3$ ) at $175 \mathrm{~V}$ for $\mathrm{hr}$ at RT using the BioRad Mini-PROTEAN 3 System.

After electrophoresis, the SDS-PAGE gel was stained in Coomassie blue solution $(0.1 \%$ w/v Coomassie Brilliant Blue R, 70\% distilled water, $40 \% \mathrm{v} / \mathrm{v}$ methanol and $10 \% \mathrm{v} / \mathrm{v}$ acetic acid) followed by de-staining overnight with de-stain solution ( $70 \%$ distilled water, $10 \%$ acetic acid, 20\% methanol) and the gel was photographed using a digital camera.

\subsection{Immunoblotting and protein visualization}

The same SDS-PAGE gel was prepared as above however this time the gel was not stained with Coomassie Blue. Instead, the proteins were transferred onto Immun-Blot polyvinylidene difluoride (PVDF) membrane (Bio-Rad, USA) by wet transfer with pre-chilled transfer buffer ( $25 \mathrm{mM}$ Tris ( $\mathrm{pH} 8.5), 192 \mathrm{mM}$ glycine, and $20 \% \mathrm{v} / \mathrm{v}$ methanol) at $4^{\circ} \mathrm{C}$ for $120 \mathrm{~min}$ at $70 \mathrm{~V}$. In order to prevent non-specific binding, PVDF membrane was blocked with $5 \%$ non-fat milk in TBST (20mM Tris (pH 7.5), $150 \mathrm{Mm} \mathrm{NaCl}$, and $0.05 \%$ Tween-20) for $30 \mathrm{~min}$ at RT. The 
blot was then washed three times with TBST for $5 \mathrm{~min}$ each wash. The blot was then incubated with $10 \mathrm{~mL}$ TBST buffer containing $5 \% \mathrm{w} / \mathrm{v} \mathrm{BSA}$ and the primary antibody against the protein of interest on a shaking platform overnight at $4^{\circ} \mathrm{C}$. The primary antibody used was his-tag polyclonal antibody diluted at 1:1000 v:v (Cell Signaling Technology, USA). The next day, the blot was washed three times with TBST for $5 \mathrm{~min}$ each wash and then incubated at RT for $1 \mathrm{hr}$ in 5\% BSA and secondary antibody diluted at 1:2000 v:v (anti-rabbit IgG, HRP-linked) (Cell Signaling Technology, USA). The target protein on the PVDF membrane was detected using an enhanced chemiluminescence (ECL) system containing 1X LumiGLO Reagent and 1X Peroxide Reagent (Cell Signaling Technology, USA). The membrane was scanned using FluorChem Q imaging system (Alpha Innotech Cooperation, USA) and the resulting image was analyzed.

\subsection{Enzyme assays}

Frozen harvested leaves treated with $0 \mathrm{hr}$ or $48 \mathrm{hr}$ water, $100 \mu \mathrm{M}$ SA, $5 \mu \mathrm{g} / \mathrm{mL}$ TM or $1 \mathrm{mM}$ DTT were homogenized in $0.05 \mathrm{~mol} / \mathrm{L}$ sodium acetate buffer $(0.1 \mathrm{~N}$ acetic acid and $0.1 \mathrm{~N}$ sodium acetate, $\mathrm{pH} 5.2$ ) using a pre-chilled pestle and mortar at $4^{\circ} \mathrm{C}$. The homogenates were centrifuged at $12,000 \mathrm{~g}$ for $20 \mathrm{~min}$ at $4^{\circ} \mathrm{C}$ and the supernatants were used as crude extract.

\subsubsection{Determination of protein concentration}

Solubilized protein concentrations in tissue extracts were determined using the Bio-Rad Protein Assay based on the method of Bradford Coomassie blue dye and BSA as the standard (Bradford, 1976). 50mL of the dye reagent was prepared by mixing $10 \mathrm{~mL}$ of the dye reagent concentrate with $40 \mathrm{~mL}$ distilled de-ionized water. This Bradford reagent was kept away from light and filtered just before use. A $1.44 \mathrm{mg} / \mathrm{mL}$ solution of BSA was diluted in the protein extraction buffer to make BSA standard curve with a linear range between $0.05 \mathrm{mg} / \mathrm{mL}$ and 
$0.5 \mathrm{mg} / \mathrm{mL} .10 \mu \mathrm{L}$ of each dilution and protein sample solutions were pipetted into separate microtiter plate wells in triplicates. $200 \mu \mathrm{L}$ of diluted Bradford dye reagent were added to each well and mixed. The plate wells were left at RT for $5 \mathrm{~min}$ and absorbance was measured at 595nm using Epoch Microplate Spectrophotometer (BioTek Instruments, USA). Then a BSA standard curve was plotted with absorbance at $595 \mathrm{~nm}$ against concentration $(\mathrm{mg} / \mathrm{mL})$. Therefore, the concentration of protein samples was determined from the BSA standard curve.

\subsection{2. $\beta$-1, 3-glucanase assay}

$0.4 \mathrm{~mL}$ of Mcllvaine's citric acid phosphate buffer $(0.2 \mathrm{M}$ dibasic sodium phosphate and $0.1 \mathrm{M}$ citric acid, $\mathrm{pH} 5.6$ ) containing $1 \mathrm{mg} / \mathrm{mL}$ laminarin were added to $0.1 \mathrm{~mL}$ of protein extract of each treatment. The samples were incubated at $37^{\circ} \mathrm{C}$ for $15 \mathrm{~min}$ and then $0.5 \mathrm{~mL}$ alkaline copper reagent $\left(12 \mathrm{~g}\right.$ Na-K-tartarate and $24 \mathrm{~g}$ anhydrous $\mathrm{Na}_{2} \mathrm{CO}_{3}$ in $250 \mathrm{~mL}$ distilled water added to $4 \mathrm{~g} \mathrm{CuSO}_{4} .5 \mathrm{H}_{2} \mathrm{O}$ and $16 \mathrm{~g} \mathrm{NaHCO}_{3}$ dissolved in $200 \mathrm{~mL}$ distilled water. This solution was added to a separate solution of $180 \mathrm{~g}$ anhydrous $\mathrm{Na}_{2} \mathrm{SO}_{4}$ in $500 \mathrm{~mL}$ boiling distilled water. The final solution was diluted to $1 \mathrm{~L}$ ) was added. The samples were heated at $100^{\circ} \mathrm{C}$ for $10 \mathrm{~min}$ then cooled on ice for $5 \mathrm{~min} .0 .5 \mathrm{~mL}$ arsenomolybdate reagent $(25 \mathrm{~g}$ ammonium molybdate dissolved in $450 \mathrm{~mL}$ distilled water, $3 \mathrm{~g}$ disodium hydrogen arsenate heptahydrate dissolved in $25 \mathrm{~mL}$ distilled water and $21 \mathrm{ml}$ concentrated $\mathrm{HCl}$. These ingredients were mixed well and digested for $24 \mathrm{hr}$ at $37^{\circ} \mathrm{C}$ ) was added to each sample. A blue color started forming and after about $5 \mathrm{~min}, 3 \mathrm{~mL}$ double distilled water was added to each tube. The absorbance of $200 \mu \mathrm{L}$ of each sample was measured at $660 \mathrm{~nm}$ using Epoch ${ }^{\mathrm{TM}}$ Multi-Volume Spectrophotometer System. 


\subsubsection{Glutamine synthetase assay}

$380 \mu \mathrm{L}$ assay mix $(100 \mathrm{mM}$ TEA, $80 \mathrm{mM}$ glutamate, $6 \mathrm{mM}$ hydroxylamine $\mathrm{HCl}, 20 \mathrm{mM}$ $\mathrm{MgSO}_{4}$, and $4 \mathrm{mM} \mathrm{EDTA}$ at $\mathrm{pH} 7.6$ ) were added to $100 \mu \mathrm{L}$ of protein extract of each sample. The reactions were started by adding $20 \mu \mathrm{L}$ of $200 \mathrm{mM}$ ATP $(\mathrm{pH}$ 7.6). All samples were incubated at $30^{\circ} \mathrm{C}$ for $10 \mathrm{~min}$ after which $500 \mu \mathrm{L}$ ferric chloride reagent $(240 \mathrm{mM}$ trichloroacetic acid (TCA), $100 \mathrm{mM}$ ferric chloride, and $1 \mathrm{M} \mathrm{HCl}$ ) was added to each tube to stop the reactions. Samples were then centrifuged at $10,000 \mathrm{~g}$ for $5 \mathrm{~min}$. The absorbance of $200 \mu \mathrm{L}$ of each sample was measured at 505nm using Epoch ${ }^{\mathrm{TM}}$ Multi-Volume Spectrophotometer System. 


\section{Chapter III}

\section{Observations, Data and Results}

\subsection{Bioinformatics analysis}

\subsubsection{Phylogenetic tree of CRT in Solanum lycopersicum and Arabidopsis thaliana}

Two CRT genes were identified in Solanum lycopersicum AK321700.1 (referred to as LeCRT1) and SGN-U578018 (referred to as LeCRT2). These two sequences are very similar at their gene level. In order to predict the proteins that could possibly interact with Solanum lycopersicum CRT, Arabidopsis thaliana CRT was examined. Two paralogous genes AT1G56340.1 and AT1G09210.1 were found to have high nucleotide sequence similarity with Solanum lycopersicum CRT when using the BLAST tool from NCBI (http://www.ncbi.nlm.nih.gov/). It is useful to look at Arabidopsis thaliana because its whole genome has been sequenced and widely studied so based on the interactions with AtCRTs we can examine if the same interactions occur with tomato CRTs. Therefore, bioinformatics analysis was done on these genes to study protein interactions and thus predict that those same interactions would occur with our CRT tomato genes. It should be noted that LeCRT1 and LeCRT2 are homologs and are very similar in sequence. The same applies for AT1G56340.1 and AT1G09210.1. The phylogenetic tree of the three Arabidopsis genes and the two tomato CRT genes is represented below (Figure 3.1). This analysis seems to indicate that the two tomato CRTs are very homologous to the three Arabidopsis CRTs. 


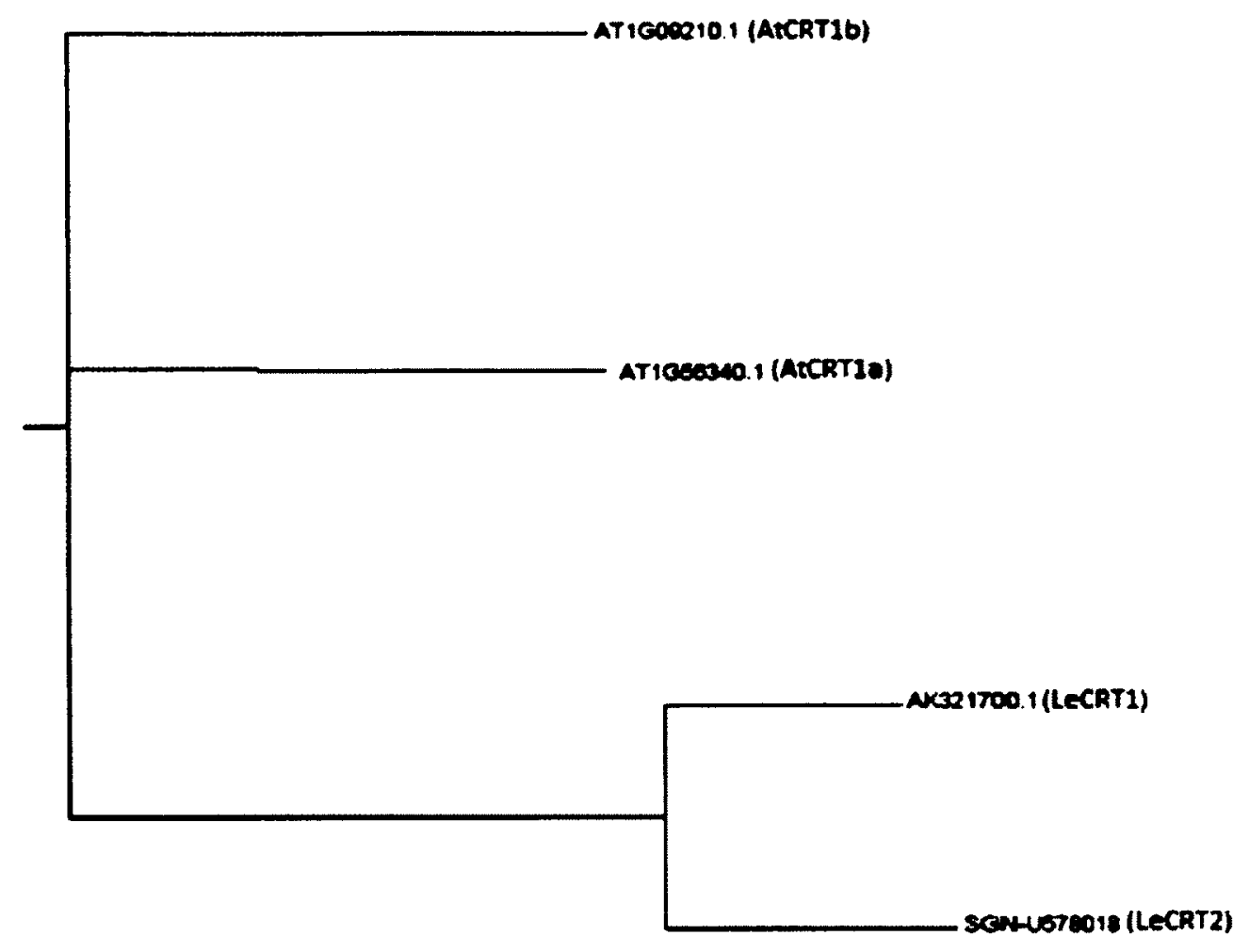

Figure 3.1: Phylogenetic tree of Arabidopsis thaliana and Solanum lycopersicum CRT genes. AK321700.1 and SGN-U578018 of Solanum lycopersicum are paralogs as well as AT1G56340.1 and AT1G09210.1 of Arabidopsis thaliana. The phylogenetic tree was generated using the ClustalW alignment tool in clustal program (www.ebi.ac.uk/clustalw/) and the Phylodendron tool (http://iubio.bio.indiana.edu/treeapp/treeprint-form.html).

\subsubsection{Analysis of Solanum lycopersicum LeCRT1 and its Arabidopsis homolog}

AK321700.1 (LeCRT1) of Solanum lycopersicum was examined whenever applicable but mostly its Arabidopsis homolog AT1G56340 was examined when data for tomato CRT was not found.

Motif analysis using ScanSite tool (http://scansite.mit.edu/) indicated the presence of two potential kinase binding domains (V306 and V438) as well as multiple protein phosphorylation 
sites in AtCRT1a (Figure 3.2). The kinase binding domains suggest the presence of ERKdocking domains used by proteins to physically interact with mitogen activated protein kinases belonging to the ERK family. This analysis may support the role of kinases (ERK-type) in the regulation of the activity of this CRT. Baso_ST_kin and Acid_ST_kin represent the basophilic and acidophilic serine/ threonine kinase groups respectively. Similarly, kin_bind shows the kinase binding site group while PTB represents the phosphotyrosine binding group. The predicted site at which each occurs is represented under the group (example S85, Y261, and V306.).

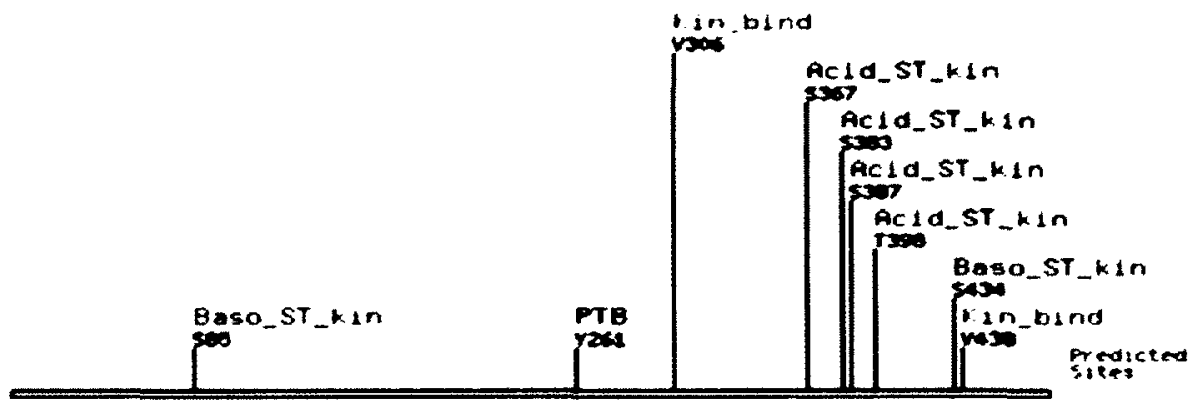

Figure 3.2: High stringency ScanSite output for AtCRT1a protein sequence indicating possible ERK docking and binding sites.

Microarray data mining was done using Genevestigator database (https://www.genevestigator.com) to examine the responses of CRT to various treatment or expression patterns in different developmental stages or in different tissues. The response of the most homologous CRT of Arabidopsis was used when that of tomato was not found. Figure 3.3 indicates that SA enhanced CRT expression in Arabidopsis while FB1 did not. 


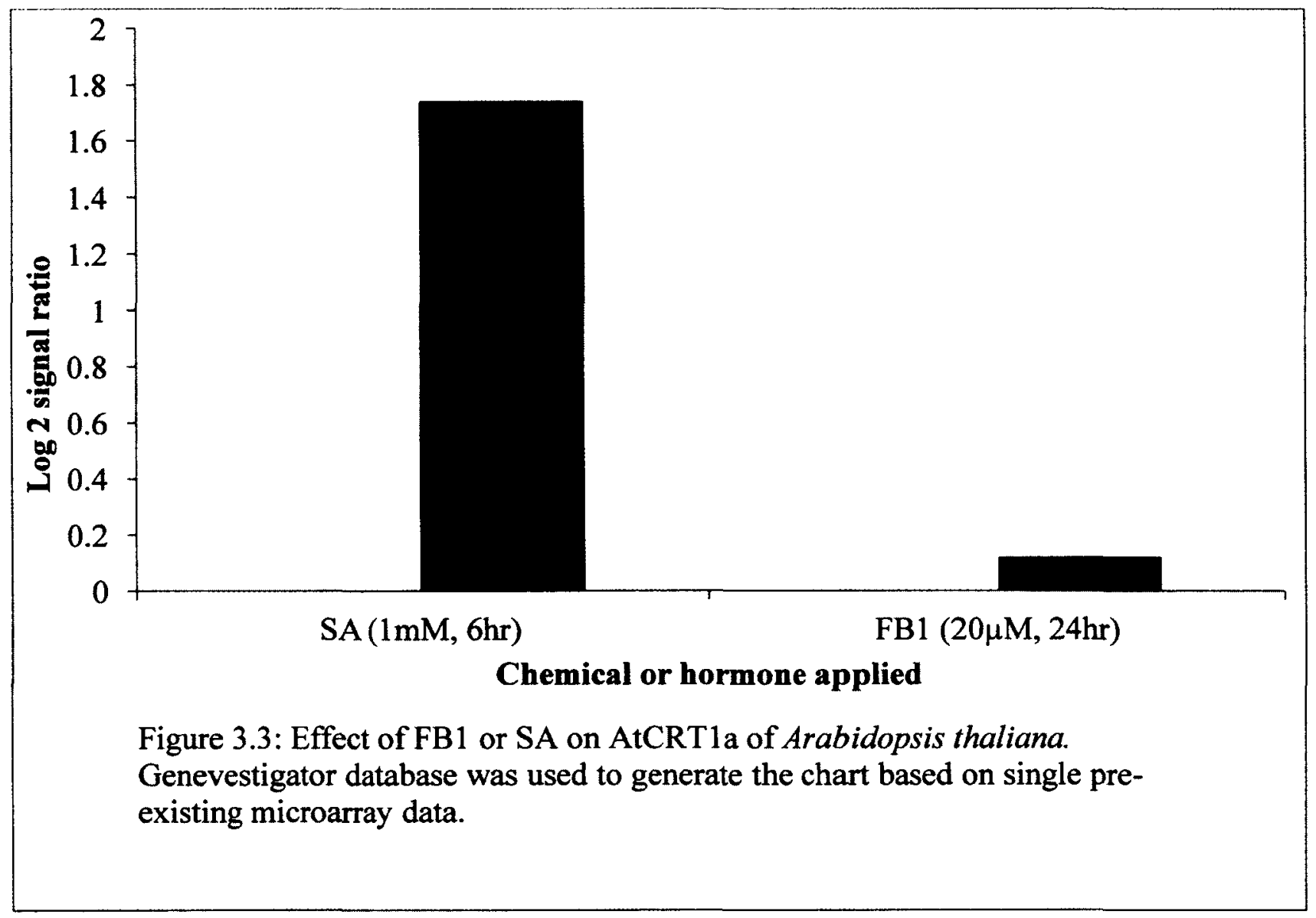

The expression levels of AK321700.1 (LeCRT1) in leaves of Solanum lycopersicum in different tissues were examined using the anatomy tool in Genevestigator (Figure 3.4). 
Overall expression of LeCRT1 (AK321700.1) in Solanum lycopersicum was obtained using the development tool in Genevestigator (Figure 3.5).

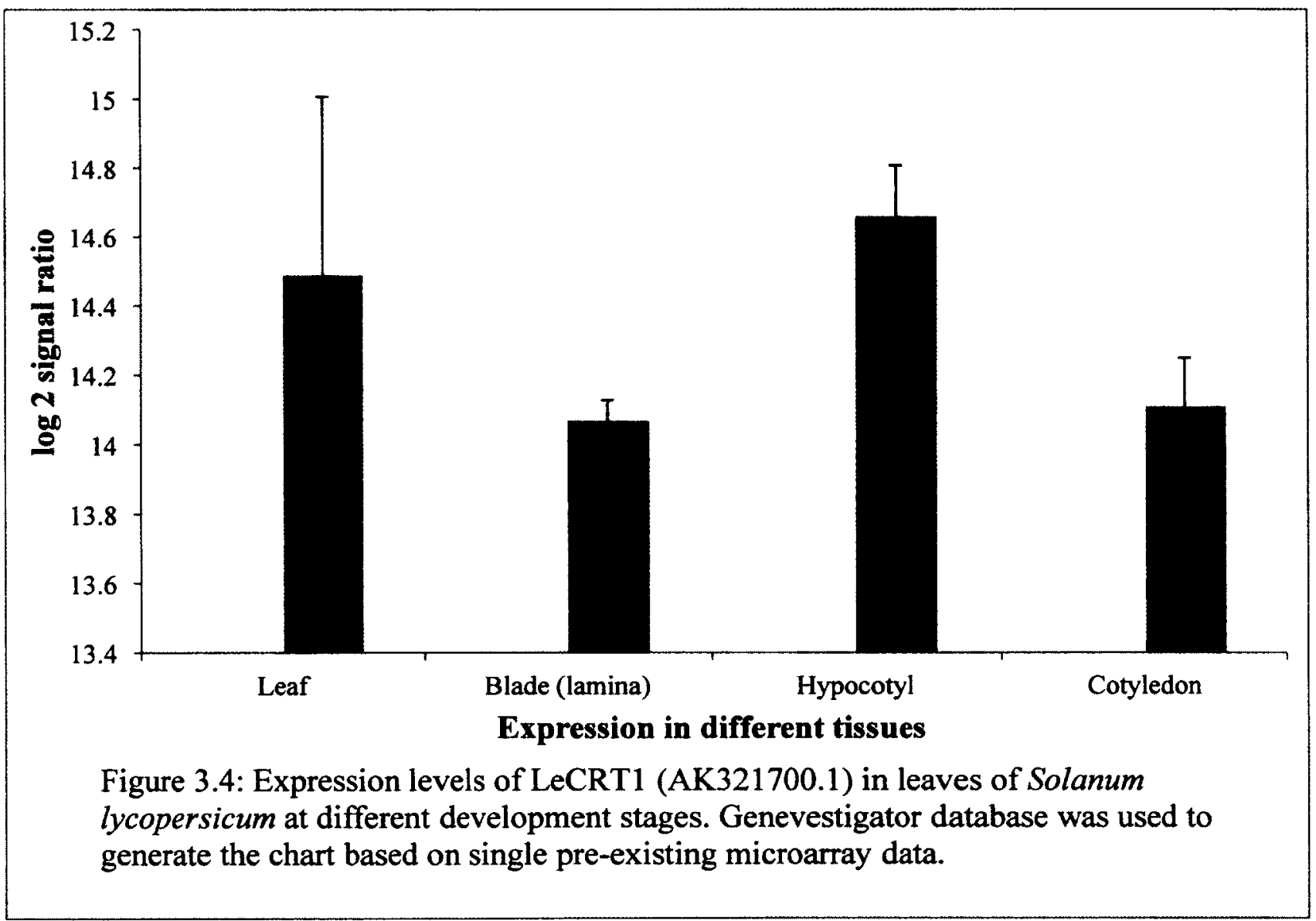




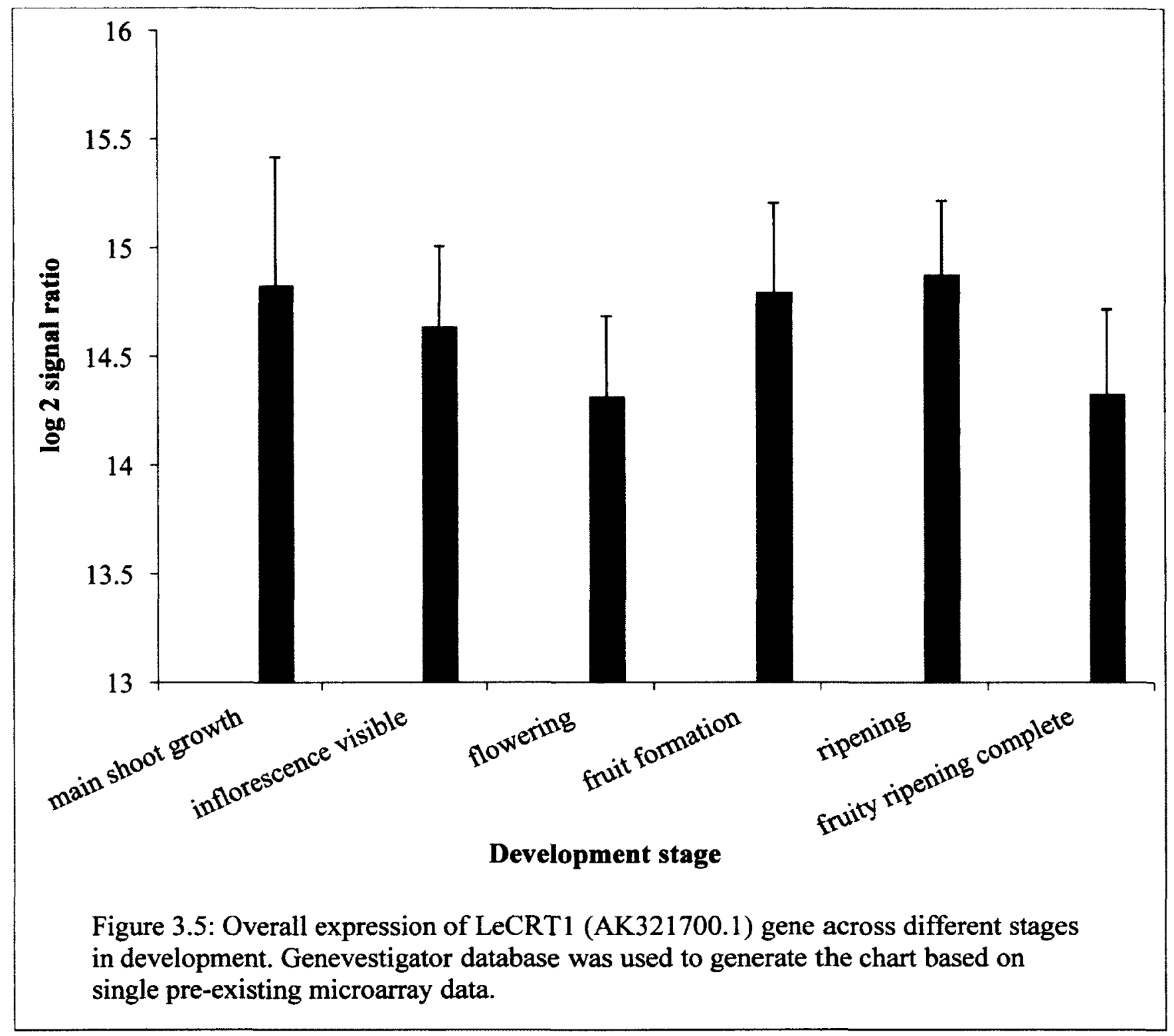

Using the STRING tool (http://string-db.org/), a database was extracted with proteins that are predicted to be co-expressed with the targeted protein of interest. In this case for example, AtCRT1a was entered. Figure 3.6 represents its interactions and co-expression with other proteins based on different modes, and Table 3.1 summarizes the prediction and function of cooccurred proteins with AtCRT1a. 


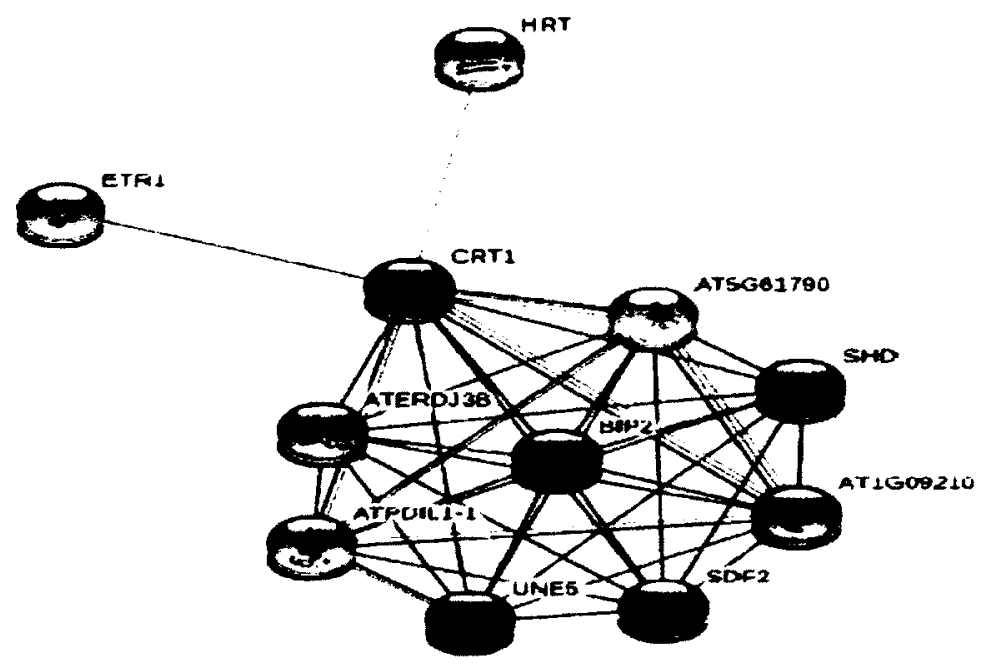

Figure 3.6: Proteins that are predicted to co-occur with AtCRT1a. Data was obtained using STRING (http://string-db.org/).

Table 3.1: Summary of mode of prediction and function of proteins that co-occur with AtCRT1a

\begin{tabular}{|l|l|l|}
\hline Protein ID/ Name & Mode of Prediction & Function \\
\hline HRT & Text mining & $\begin{array}{l}\text { Induction of hypersensitive response and } \\
\text { resistance to turnip crinkle virus }\end{array}$ \\
\hline $\begin{array}{l}\text { AT1G09210 } \\
\text { (AtCRT1b) }\end{array}$ & $\begin{array}{l}\text { Co-expression/ } \\
\text { Homology/ Text mining }\end{array}$ & $\begin{array}{l}\text { Unfolded protein binding and calcium ion } \\
\text { binding }\end{array}$ \\
\hline AT5G61790 (CNX1) & $\begin{array}{l}\text { Co-expression/ } \\
\text { Homology }\end{array}$ & $\begin{array}{l}\text { Unfolded protein binding and calcium ion } \\
\text { binding }\end{array}$ \\
\hline BIP2 & Co-expression & ATP binding; luminal binding protein (BiP) \\
\hline ETR1 & Experiments & $\begin{array}{l}\text { Ethylene binding / protein histidine kinase/ } \\
\text { two-component response regulator }\end{array}$ \\
\hline SHD & Co-expression & ATP binding and unfolded protein binding \\
\hline ATPDIL1-1 & Co-expression & Protein disulfide isomerase \\
\hline UNE5 & Co-expression & Protein disulfide isomerase \\
\hline SDF2 & Co-expression & Unknown \\
\hline ATERDJ3B & Co-expression & $\begin{array}{l}\text { Heat shock protein binding and unfolded } \\
\text { protein binding }\end{array}$ \\
\hline
\end{tabular}




\subsubsection{Analysis of Solanum lycopersicum LeCRT2 and its Arabidopsis homolog}

SGN-U578018 (LeCRT2) of Solanum lycopersicum was examined whenever applicable but mostly its Arabidopsis homolog AT1G09210.1 was examined when data for tomato CRT was not found.

Motif analysis using ScanSite tool of Arabidopsis AtCRT1b indicated the presence of multiple potential kinase binding domains and protein phosphorylation sites (Figure 3.7). A potential $\mathrm{SH} 2$ binding site is predicted too, which may suggest the possible interaction of this CRT with other proteins. This analysis may support the role of kinases in the regulation of the activity of this CRT. Moreover, the presence of a possible kinase binding site (L305) suggests the presence of ERK-docking domains used by proteins to physically interact with mitogen activated protein kinases belonging to the ERK family. This analysis may support the role of kinases (ERK-type) in the regulation of the activity of this CRT.

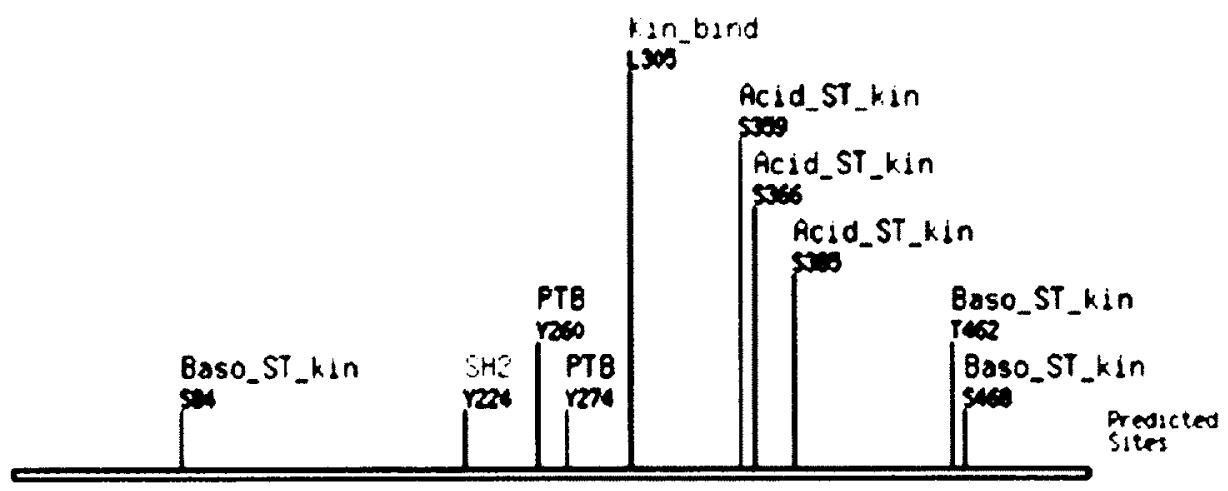

Figure 3.7: High stringency ScanSite output for AtCRT1b protein sequence indicating possible ERK docking and binding sites. 
Similar to LeCRT1, microarray data mining was done using Genevestigator database to examine the responses of CRT to various treatment or expression patterns in different developmental stages or in different tissues. The response of the most homolog CRT Arabidopsis was used when that of tomato was not found. Figure 3.8 indicates that salicylic acid (SA) enhanced CRT expression in Arabidopsis while FB1 did not as much. It is predicted that the same effect will occur with tomato CRT.

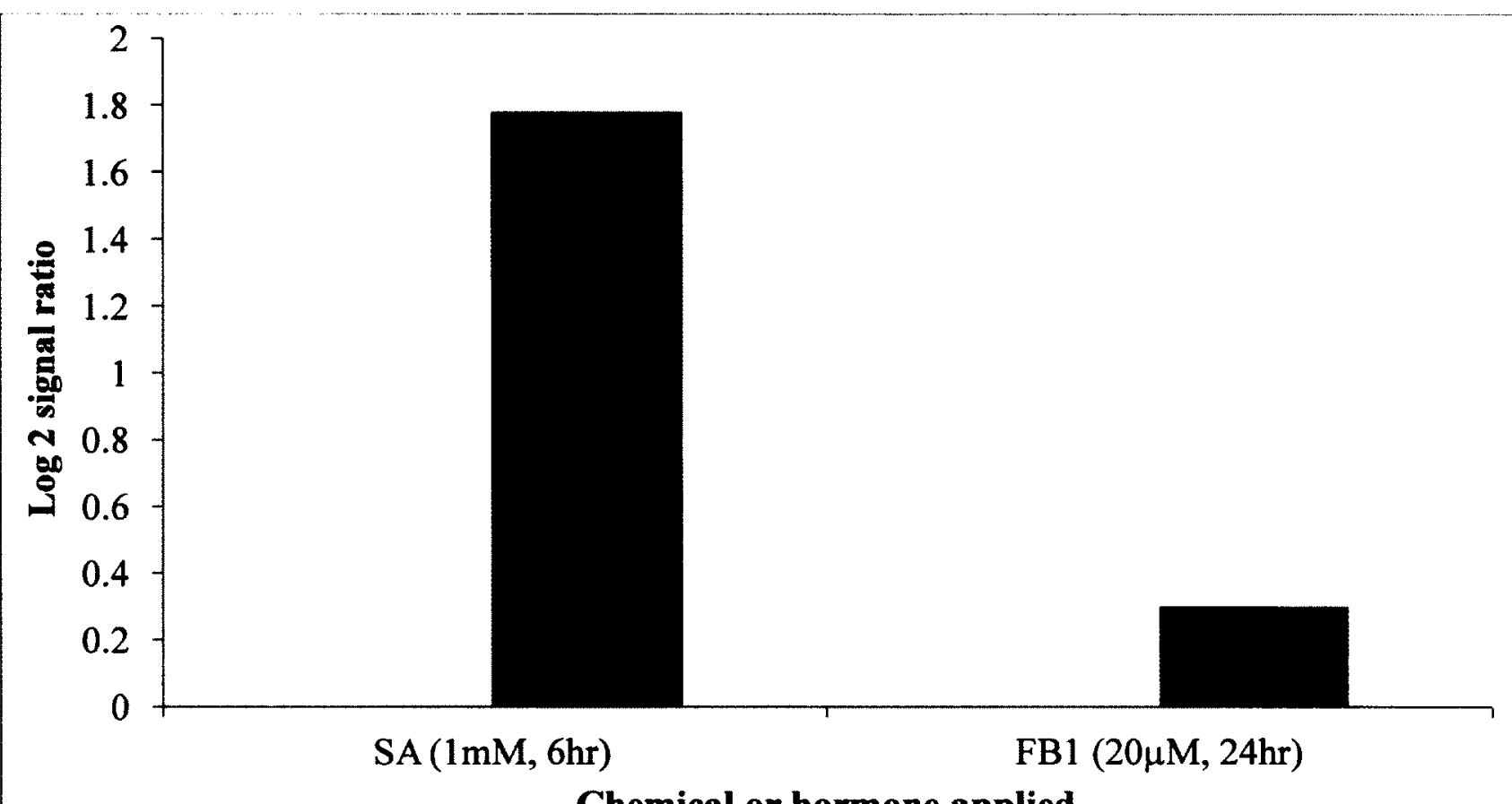

Chemical or hormone applied

Figure 3.8: Effect of chemical treatment FB1 or hormone SA on AtCRT1b of Arabidopsis thaliana. Genevestigator database was used to generate the chart based on single pre-existing microarray data.

The expression levels of AT1G09210.1 (AtCRT1b) in rosette leaves of Arabidopsis thaliana in different tissues were examined using the anatomy tool in Genevestigator (Figure 3.9). 


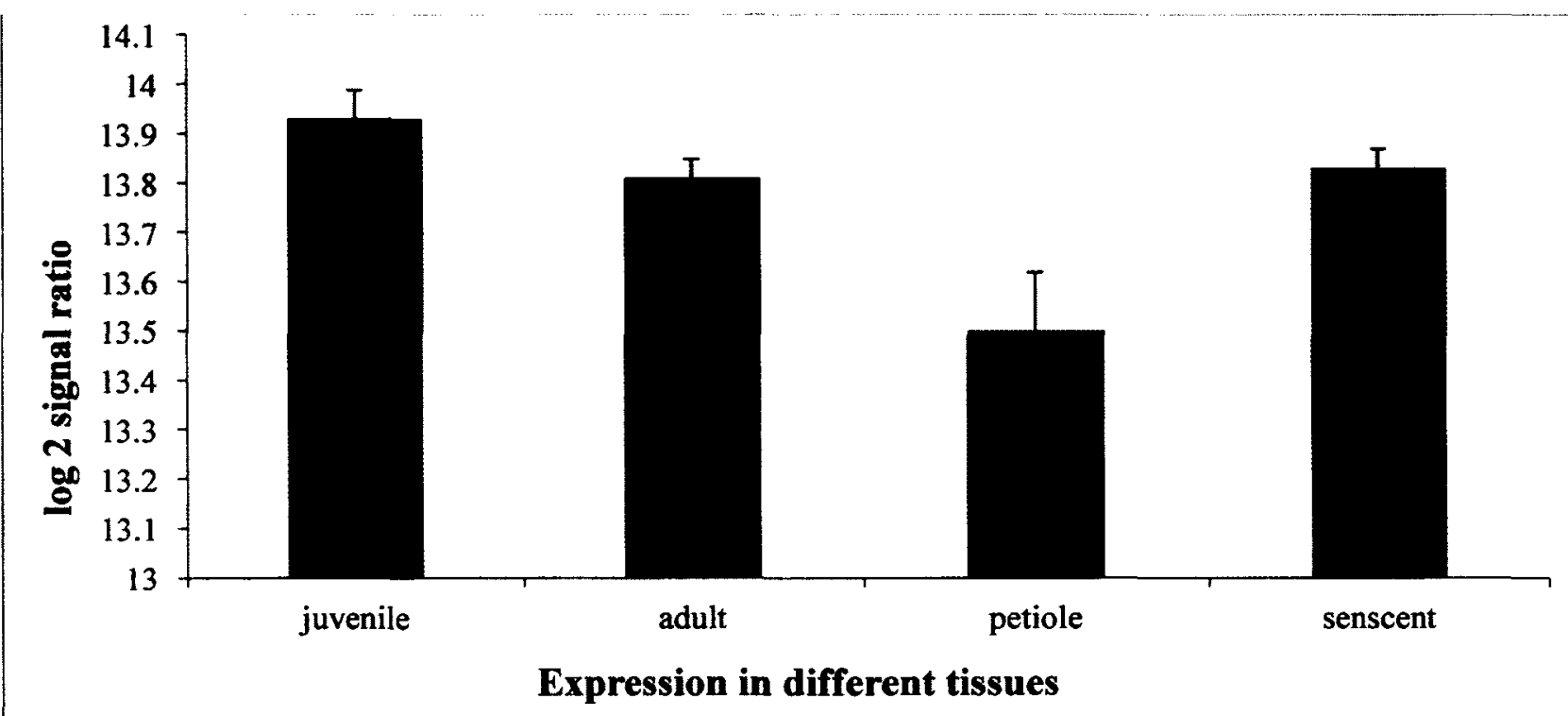

Figure 3.9: Expression levels of AtCRT1b in rosette leaves of Arabidopsis thaliana at different development stages. Genevestigator database was used to generate the chart based on single pre-existing microarray data.

Overall expression of AT1G09210.1 (AtCRT1b) in Arabidopsis thaliana was obtained using the development tool in Genevestigator (Figure 3.10). 


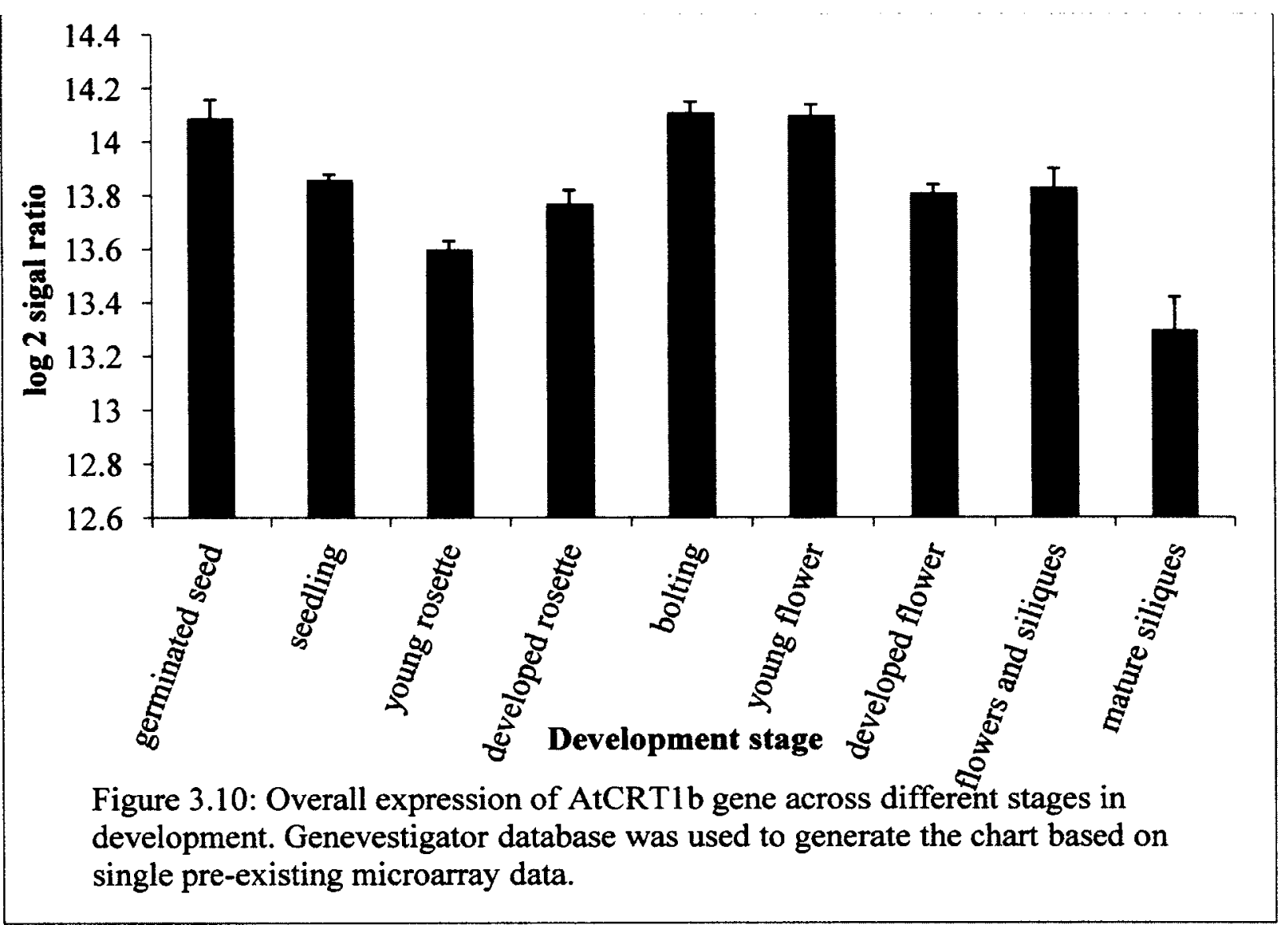

Using the STRING tool (http://string-db.org/), proteins that are predicted to be coexpressed with AtCRT1b were examined. Figure 3.11 represents interactions and co-expression with other proteins based on different modes and Table 3.2 summarizes the prediction and function of co-occurred proteins with AtCRT1b. 


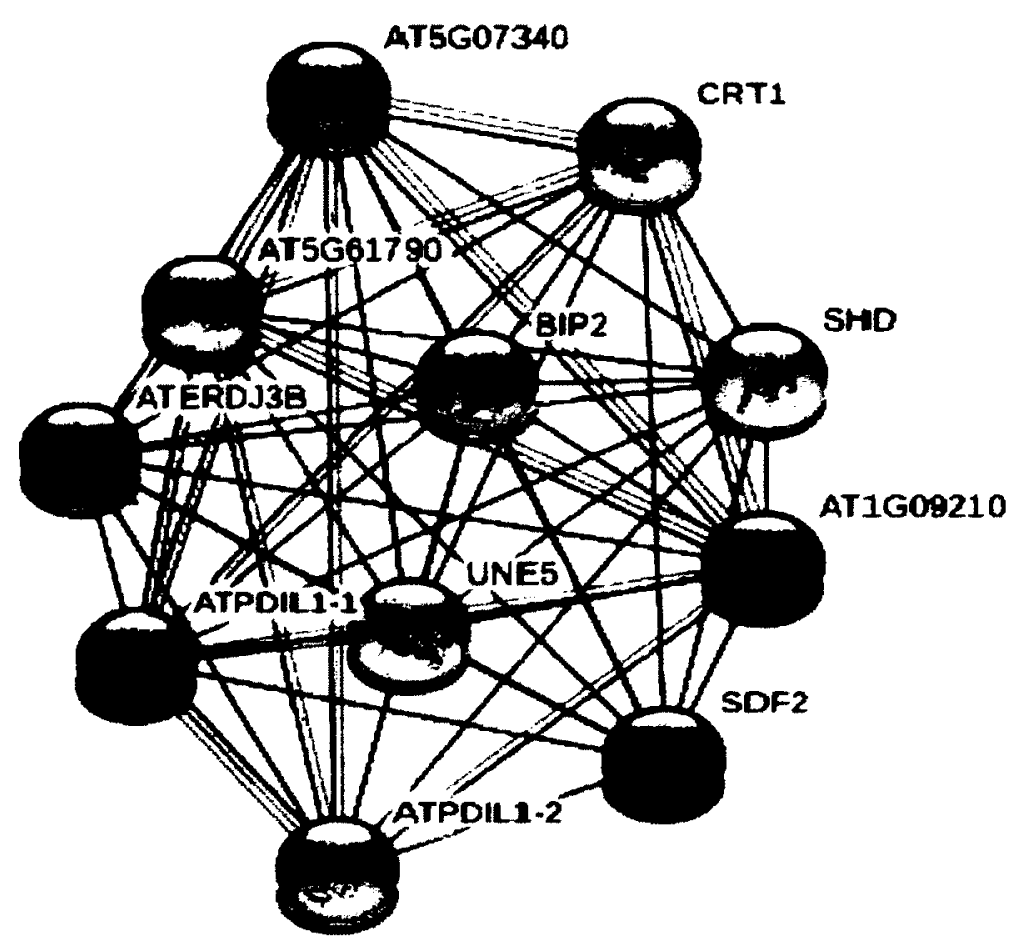

Figure 3.11: Proteins that are predicted to co-occur with AtCRT1b. Data was obtained using STRING (http://string-db.org/).

Table 3.2: Summary of mode of prediction and function of proteins that co-occur with AtCRT1b.

\begin{tabular}{|l|l|l|}
\hline Protein ID/ Name & Mode of Prediction & Function \\
\hline $\begin{array}{l}\text { AT1G56340 } \\
\text { (AtCRT1a) }\end{array}$ & $\begin{array}{l}\text { Co-expression/ } \\
\text { Homology/ Text mining }\end{array}$ & $\begin{array}{l}\text { Unfolded protein binding and calcium ion } \\
\text { binding }\end{array}$ \\
\hline AT5G61790 (CNX1) & $\begin{array}{l}\text { Co-expression/ } \\
\text { Homology }\end{array}$ & $\begin{array}{l}\text { Unfolded protein binding and calcium ion } \\
\text { binding }\end{array}$ \\
\hline SHD & Co-expression & ATP binding an unfolded protein binding \\
\hline ATPDIL1-1 & Co-expression & Protein disulfide isomerase \\
\hline BIP2 & Co-expression & ATP binding; luminal binding protein (BiP) \\
\hline ATERDJ3B & Co-expression & $\begin{array}{l}\text { Heat shock protein binding and unfolded } \\
\text { protein binding }\end{array}$ \\
\hline UNE5 & Co-expression & Protein disulfide isomerase \\
\hline SDF2 & Co-expression & Unknown \\
\hline AT5G07340(CNX) & $\begin{array}{l}\text { Co-expression/ } \\
\text { Homology }\end{array}$ & $\begin{array}{l}\text { Unfolded protein binding and calcium ion } \\
\text { binding }\end{array}$ \\
\hline ATPDIL1-1 & Co-expression & Protein disulfide isomerase \\
\hline
\end{tabular}




\subsection{CRT gene and motif analysis}

The cDNA of the CRT gene studied is 1143 base pairs in length and therefore makes 380 amino acids as shown in Figure 3.12. All known plant CRTs have highly conserved organization of the molecular and functional domains.

1 atgctagtagtcgccgccgccgccgaagttttcttccaggaaagcttcaatgatggttgg

$\begin{array}{llllllllllllllllllll}M & L & V & V & A & A & A & A & E & V & E & E & Q & E & S & E & N & D & G & W\end{array}$

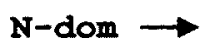

61 gaagcaggtgggtaaa tctgaatggaagaaagatgaaacatggctggagagtggaat

$\begin{array}{llllllllllllllllllll}E & S & R & W & V & K & S & E & W & K & K & D & E & N & M & A & G & E & W & N\end{array}$

121 cacacotctgggaagtggatggtgacgccaatgacaagggtattcagaccagtgaagac

$\begin{array}{llllllllllllllllllll}H & T & S & G & K & W & N & G & D & A & N & D & K & G & I & Q & T & S & E & D\end{array}$

181 tacaggttctacgccattcogotgagttccctgaatttagtaacaagggaagaactta

$Y \quad R$

G K

241 gtgttccagttctctgttaagcatgagcagaagcttgactgtggtggtgggtacatgaag

\begin{tabular}{lllllllllllllllll} 
& $H$ & $E$ & $Q$ & $K$ & $L$ & $D$ & $C$ & $G$ & $G$ & $G$ & $Y$ & $M$ & $K$ \\
\hline CRT motif & 1
\end{tabular}

301 ttgcttagtggagacgttgaccaaagaatteggtggtgacactccctacagtatcatg

$\begin{array}{llllllllllllllllllll}L & L & S & G & D & V & D & Q & K & K & F & G & G & D & T & P & Y & S & I & M\end{array}$

361 tttggaccagacatctgtggctacagtaccaagaagtccatgctattctcacttataac $\begin{array}{lllllllllllllllllllllllllllll}E & G & P & D & I & C & G & Y & S & T & K & K & V & H & A & I & L & T & Y & N\end{array}$

421 gagacaaaccatttgatcaagaaggaagtcccatgtgagactgatcagctgacccatgtc $\begin{array}{llllllllllllllllllll}\text { E } & \mathrm{T} & \mathrm{N} & \mathrm{H} & \mathrm{L} & \mathrm{I} & \mathrm{K} & \mathrm{K} & \mathrm{E} & \mathrm{V} & \mathrm{P} & \mathrm{C} & \mathrm{E} & \mathrm{T} & \mathrm{D} & \mathrm{Q} & \mathrm{I} & \mathrm{T} & \mathrm{H} & \mathrm{V}\end{array}$

481 tacactttcatcctccgtcctgatgccacatacagtattctcattgacaatgtggagaaa $\begin{array}{lllllllllllllllllllllllllllll}Y & T & F & I & L & R & P & D & A & T & Y & S & I & L & I & D & N & V & E & K\end{array}$

541 cagtctggtagcttgtactctgattgggacattctcccaccaaagaagatcaaggatcca

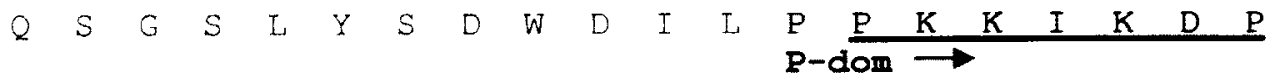

601 agtgccaagaacctgaagattgggatgacaaggaattcattgatgatccogaggataag

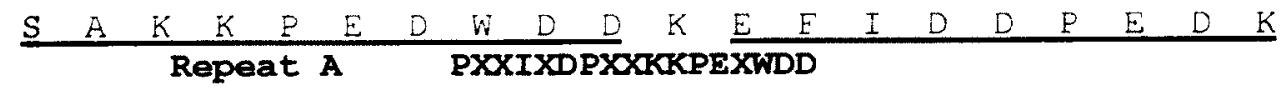

661 aagcoagagggctatgatgacattccagaggagatadctgatcctgaagccaagaagcca

$\begin{array}{llllllllllllllllllll}K & P & E & G & Y & D & D & I & P & E & E & I & T & D & P & E & A & K & K & E\end{array}$ 
721 gaggactgggatgatgaagaagatggtgaatggacagccccaaccatccccarccagag

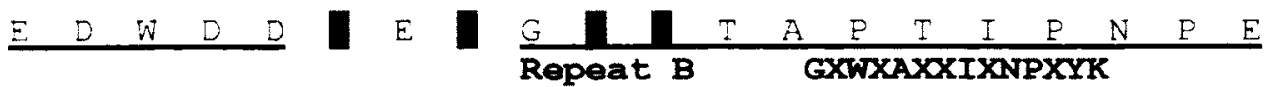

781 tacaagggccoatggaaggcaaagaaatcaagaaccccaactacaagggaaagtggaag

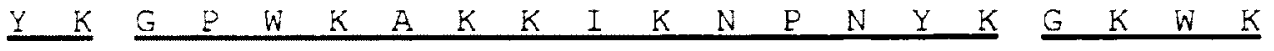

84! gotcotatgatlgacazccoagact tcagggatgacccagatctatatgttttcccaaa

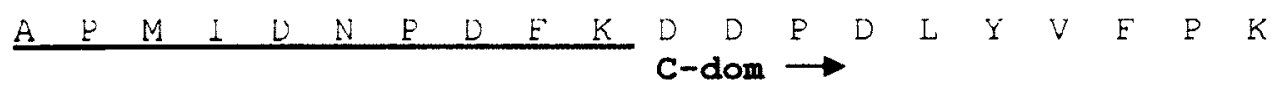

901 ttgagtatgttggagtggagctgtggcaagtgaatctggaactttgtttgacaatgtt

$\begin{array}{llllllllllll}\mathrm{L} & \mathrm{K} & \mathrm{S} & \mathrm{G} & \mathrm{T} & \mathrm{L} & \mathrm{E} & \mathrm{D} & \mathrm{N} & \mathrm{V}\end{array}$

961 gtgatatgcgatgatccagagtttgccaagtcaattgcagaggaaacatggggaagcag

$\begin{array}{llllllllllllllllllll}V & I & C & D & D & P & E & F & A & K & S & I & A & E & E & T & W & G & K & Q\end{array}$

1021 aaggatgctgaaaggctgctttgaggaagcagaaaagaagagagaggaggaggaatca $\begin{array}{llllllllllllllllllll}K & D & A & E & K & A & A & F & E & E & A & E & K & K & R & E & E & E & E & S\end{array}$

1081 aagaatgctccagctgaatctgatgccgatgaagatgacgaggctgatgaggctgattca $\begin{array}{llllllllllllllllllll}K & N & A & P & A & E & S & D & A & D & E & D & D & E & A & D & E & A & D & S\end{array}$

1141 taa

Figure 3.12: Nucleotide sequence and the corresponding amino acid sequence of tomato CRT gene. The three sequence tags are highlighted in green. The conserved CRT family signature motifs 1 and 2 are underlined. Solid triangles $(\nabla)$ represent the positions of three cysteine residues that are highly conserved. The $\mathrm{A}$ and $\mathrm{B}$ triplicate repeats are indicated with bold underline. The putative nuclear targeting sequence (PPKXIKDPX) is highlighted in yellow while the critical four amino acid residues (glutamic acid, aspartic acid, glutamic acid, and tryptophan) are highlighted in blue. The approximate positions of the three domains $(\mathrm{N}, \mathrm{P}$, and $\mathrm{C})$ are indicated with arrows. The stop codon is indicated by an asterisk.

Figure 3.13 shows the alignment of CRT of Solanum lycopersicum SGN-U578018 and Arabidopsis thaliana AT1G09210.1 and AT1G56340.1 at the amino acid level. 
AT1G09210 1

AT1G56340-1

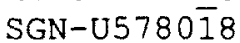

AT1G09210 1 AT $1 G 56340^{-1} 1$

SGN-U5780 $\overline{1} 8$

AT1G09210 I AT IG56340 1 SGN-U578018

ATIG09210 1 AT1G5 $6340^{-1} 1$ SGN-U5780 $\overrightarrow{18}$

AT1G09210 1 ATIG56340 1 SGN-U578018

186
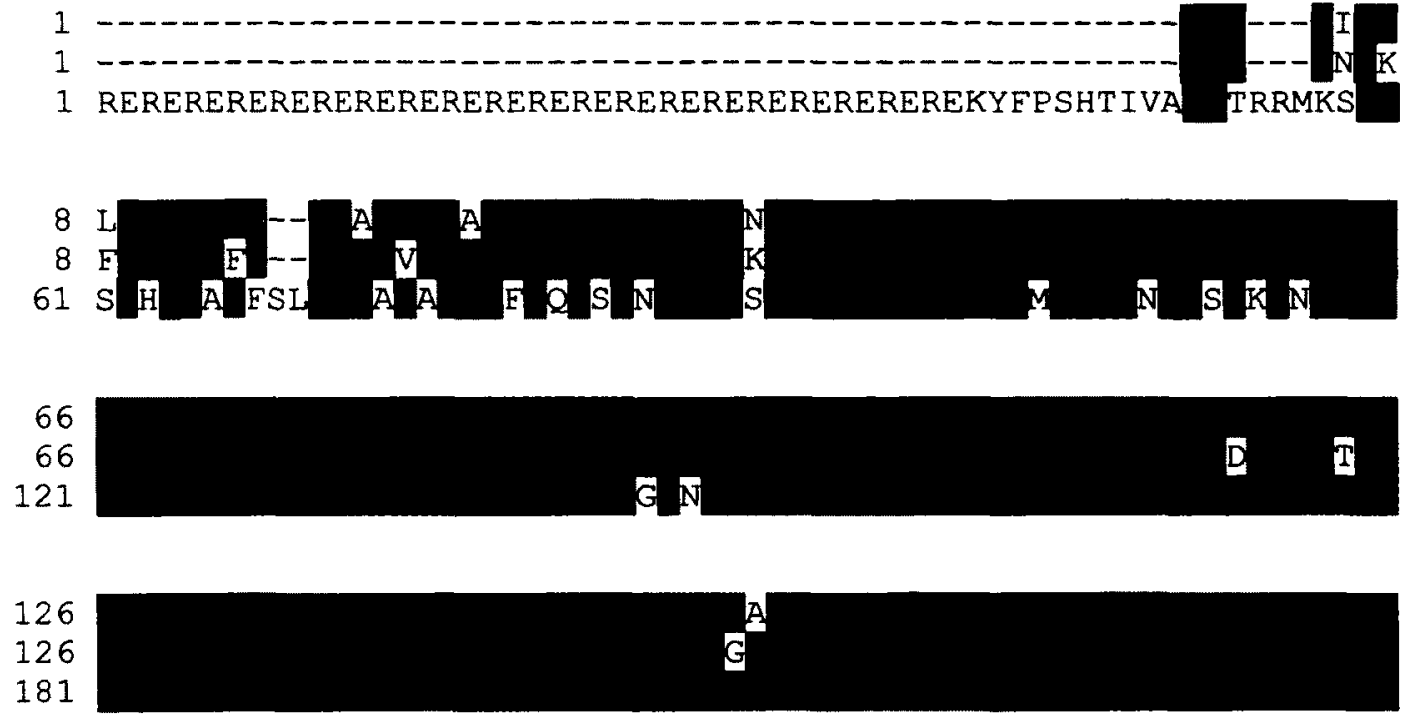

AT1G09210_1 246 AT1G56340-1 246 SGN-U578018 301

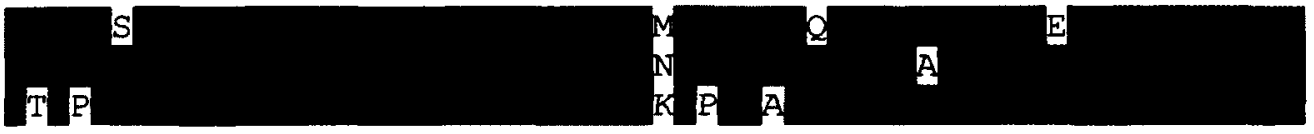

$\begin{array}{ll}\text { AT1G09210_1 } & 306 \\ \text { AT1G56340-1 } & 306\end{array}$

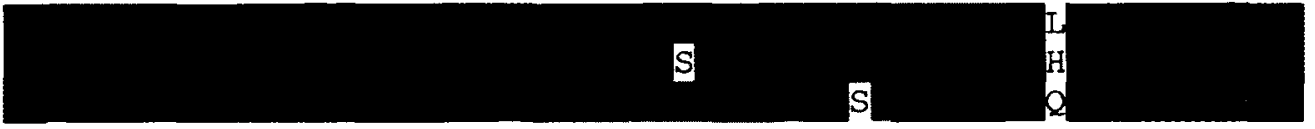

AT1G09210 1 366 AT 1 G56340-1 366 SGN-U578018 421

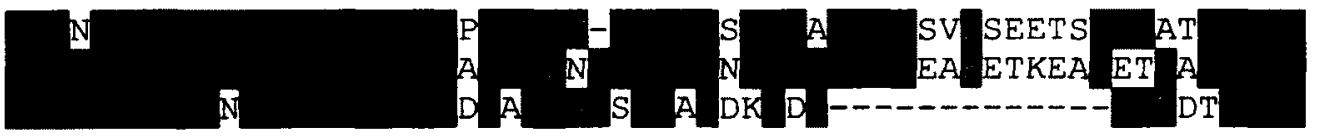

Figure 3.13: Amino acid alignment of CRT of Solanum lycopersicum SGN-U578018 and Arabidopsis thaliana AT1G09210.1 and AT1G56340.1. Amino acids shaded in black are shared in at least two sequences. Amino acids shaded in grey share similar properties on the different protein sequences.

\subsection{Solanum lycopersicum plant growth and leaf treatment}

Plants were grown under long day conditions in a growth chamber with $16 \mathrm{~h}$ light and $8 \mathrm{~h}$ dark exposure over the period of three weeks (Figure 3.14). The leaves were then cut out and the 
appropriate treatment was applied for $0 \mathrm{~h}$ or $48 \mathrm{~h}$ incubation then instantly frozen with liquid nitrogen as shown in Figure 3.15.

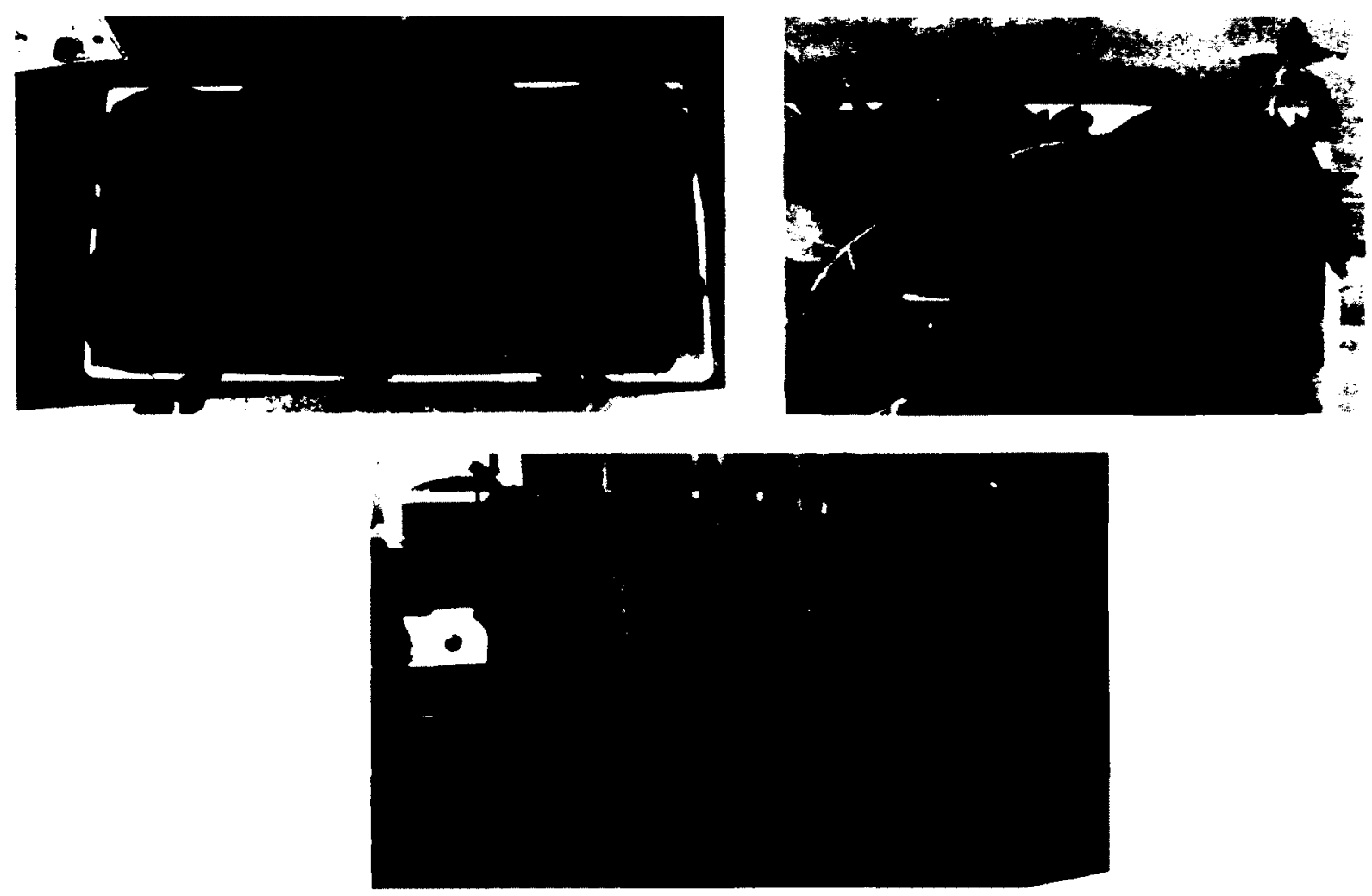

Figure 3.14: Images taken by a digital camera of different batches of three week old Solanum lycopersicum plants grown in the growth chamber under long day conditions of $16 \mathrm{~h}$ light and $8 \mathrm{~h}$ dark. 

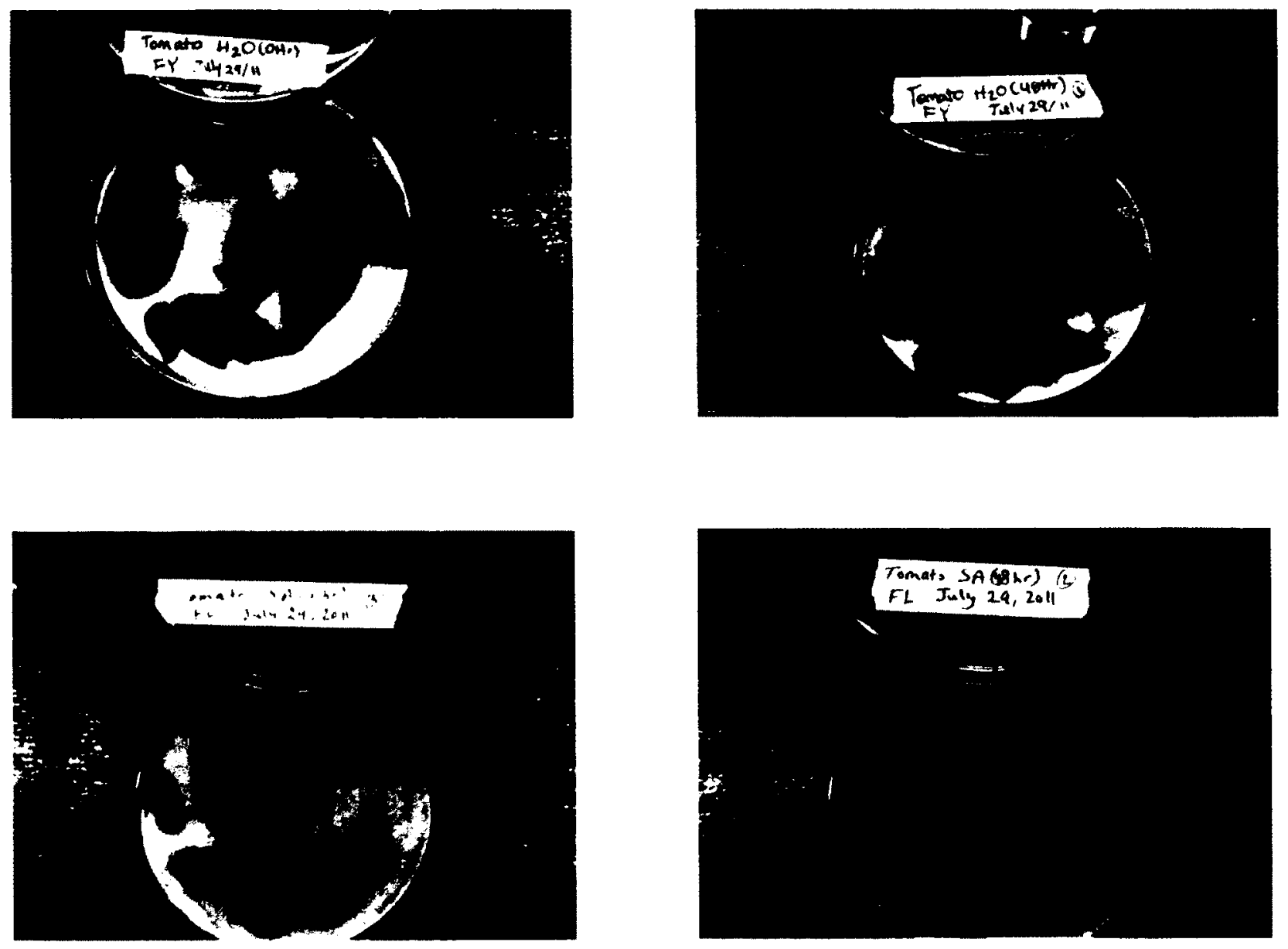

Figure 3.15: Examples of some platted leaves treated for $0 \mathrm{~h}$ or $48 \mathrm{~h}$ after which the leaves were frozen with liquid nitrogen. The plate images were taken with a digital camera and show leaves treated with either distilled water or $100 \mu \mathrm{M}$ SA.

\subsection{Finding the appropriate annealing temperature for CRT primers}

The gradient of temperatures ranged from $55.0^{\circ} \mathrm{C}$ to $64.0^{\circ} \mathrm{C}$. As seen in Figure 3.16 below the bands of brightest intensity were obtained at $55.0^{\circ} \mathrm{C}, 55.2^{\circ} \mathrm{C}$, and $55.8^{\circ} \mathrm{C}$. Therefore, the temperature used as the annealing temperature in RT-PCR to amplify CRT for our purposes was $55.5^{\circ} \mathrm{C}$. 


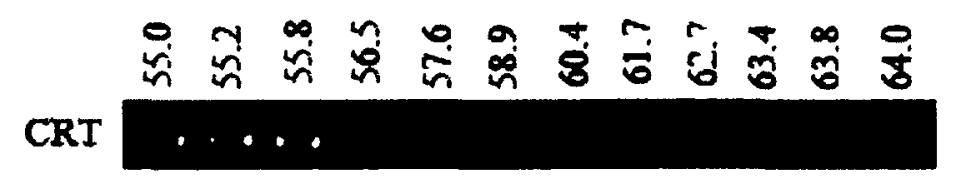

Figure 3.16: The gradient of temperatures ranging from $55.0^{\circ} \mathrm{C}$ to $64.0^{\circ} \mathrm{C}$ in order to find the best annealing temperature for RT-PCR primers to amplify CRT. The first three temperatures gave the most intense bands.

\subsection{Effect of FB1 on CRT expression}

cDNA concentration was normalized with actin gene and the effect of $5 \mu \mathrm{M}$ FB1 is shown in Figure 3.17. No change in CRT gene expression was observed with the treatment of $5 \mu \mathrm{M}$ FB1. This experiment was repeated three times and the same results were observed.

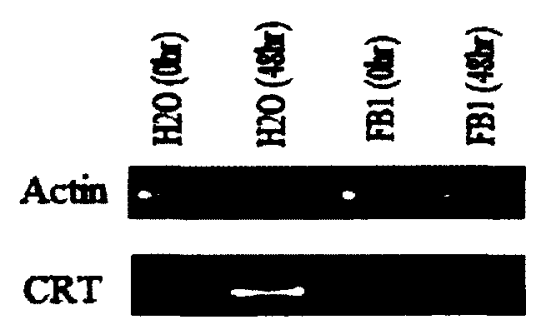

Figure 3.17: RT-PCR determination of the expression of CRT gene for Solanum lycopersicum. FB1 used in this experiment was at $5 \mu \mathrm{M}$. Actin was used as internal standard. This experiment was done three times with similar results.

\subsection{Effect of ERK inhibitor (ERKi) on CRT expression}

\subsubsection{Normalization of CRT expression using actin gene}

In order to have an equivalent amount of cDNA from each treatment, actin gene was used as the control. All concentrations were diluted to $500 \mathrm{ng} / \mu \mathrm{L}$ before PCR. 


\subsubsection{RT-PCR using actin and CRT primers}

The expression of CTR was increased in both $48 \mathrm{~h}_{2} \mathrm{O}$ and $48 \mathrm{hr}$ SA treatments while no expression occurred in $48 \mathrm{~h} \mathrm{SA}$ and ERK inhibitor treatment.

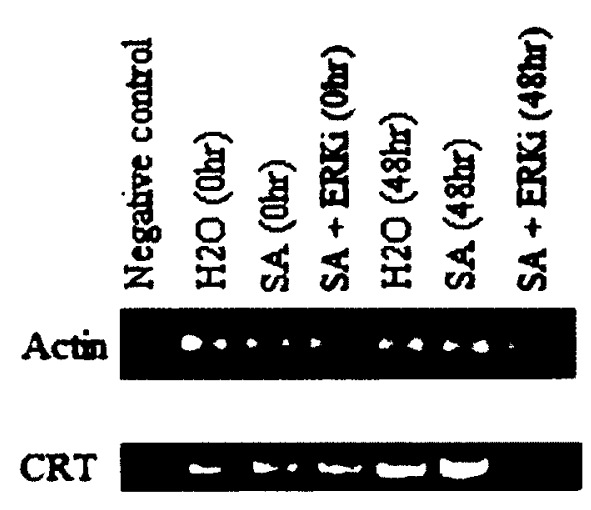

Batel 1
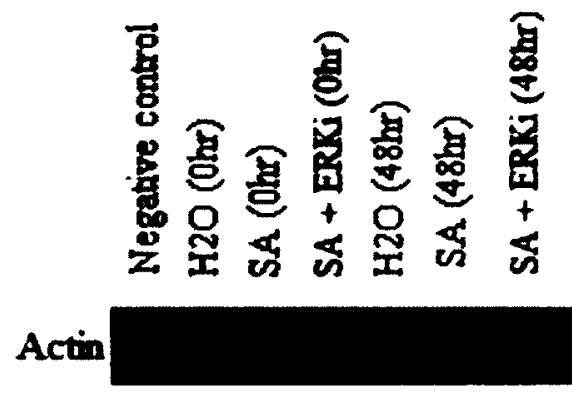

CRT

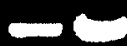

Batch 2

Figure 3.18: RT-PCR determination of the expression of CRT gene for two batches grown under the same conditions at different times. Salicylic acid used in this experiment was at $100 \mu \mathrm{M}$ while ERK inhibitor was at $250 \mu \mathrm{M}$. Actin was used as internal standard. This experiment was done twice with similar results.

\subsection{Endoplasmic reticulum (ER) stress-inducing agents (TM and DTT)}

\subsubsection{Normalization of CRT expression using actin gene}

Similar to the previous experiment, actin gene was used in order to have an equivalent amount of cDNA from each treatment. All concentrations were diluted to $500 \mu \mathrm{L}$ before RTPCR. 


\subsubsection{RT-PCR using actin and CRT primers}

Generally the expression of CRT was increased in $48 \mathrm{~h}$ treatments while it was fairly the same at $0 \mathrm{~h}$ treatments. Tunicamycin and dithiothreitol induce ER stress and they seemed to enhance CRT expression like in the salicylic acid case. This increase was even more enhanced when the leaves were treated with TM or DTT combined with SA as shown in Figure 3.19.

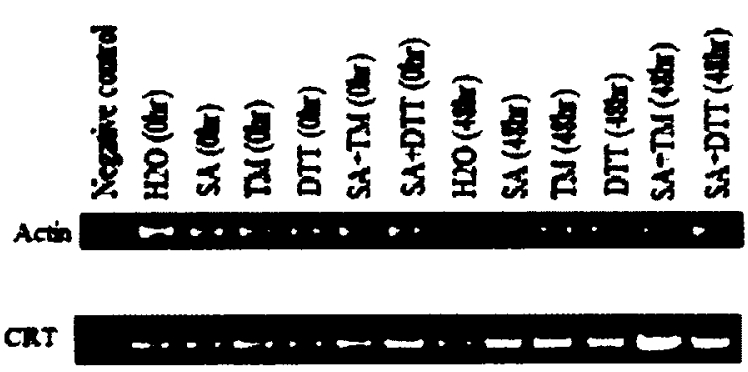

Bacel 1

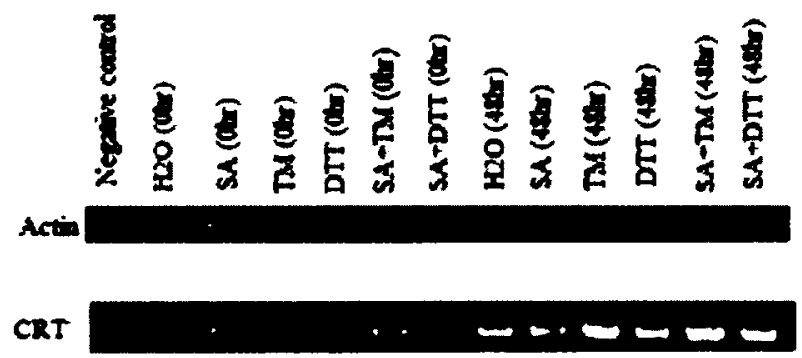

Bated 2

Figure 3.19: Expression of actin and CRT genes for two batches grown under the same conditions at different times. The stress was induced by using SA at $100 \mu \mathrm{M}, \mathrm{TM}$ at $5 \mu \mathrm{g} / \mathrm{mL}$ and DTT at $1 \mathrm{mM}$. This experiment was done twice with similar results.

\subsubsection{Statistical analysis of significance of SA treatment on CRT}

The expression of CRT under both $\mathrm{H}_{2} \mathrm{O}$ and SA (at $0 \mathrm{hr}$ and $48 \mathrm{hr}$ ) was tested 4 times in total (Figures 3.18 and 3.19). This allows for the graphical representation of the significance of the effect of each treatment on CRT expression. Figure 3.20 shows the mean values of the integrated density value (IDV) of each treatment. As seen in the figure, SA has the highest effect on CRT expression. A t-test analysis shows a p-value of 0.038 which is smaller than 0.05 and therefore 
the null hypothesis is rejected meaning there is a significant difference between SA treatment and control.

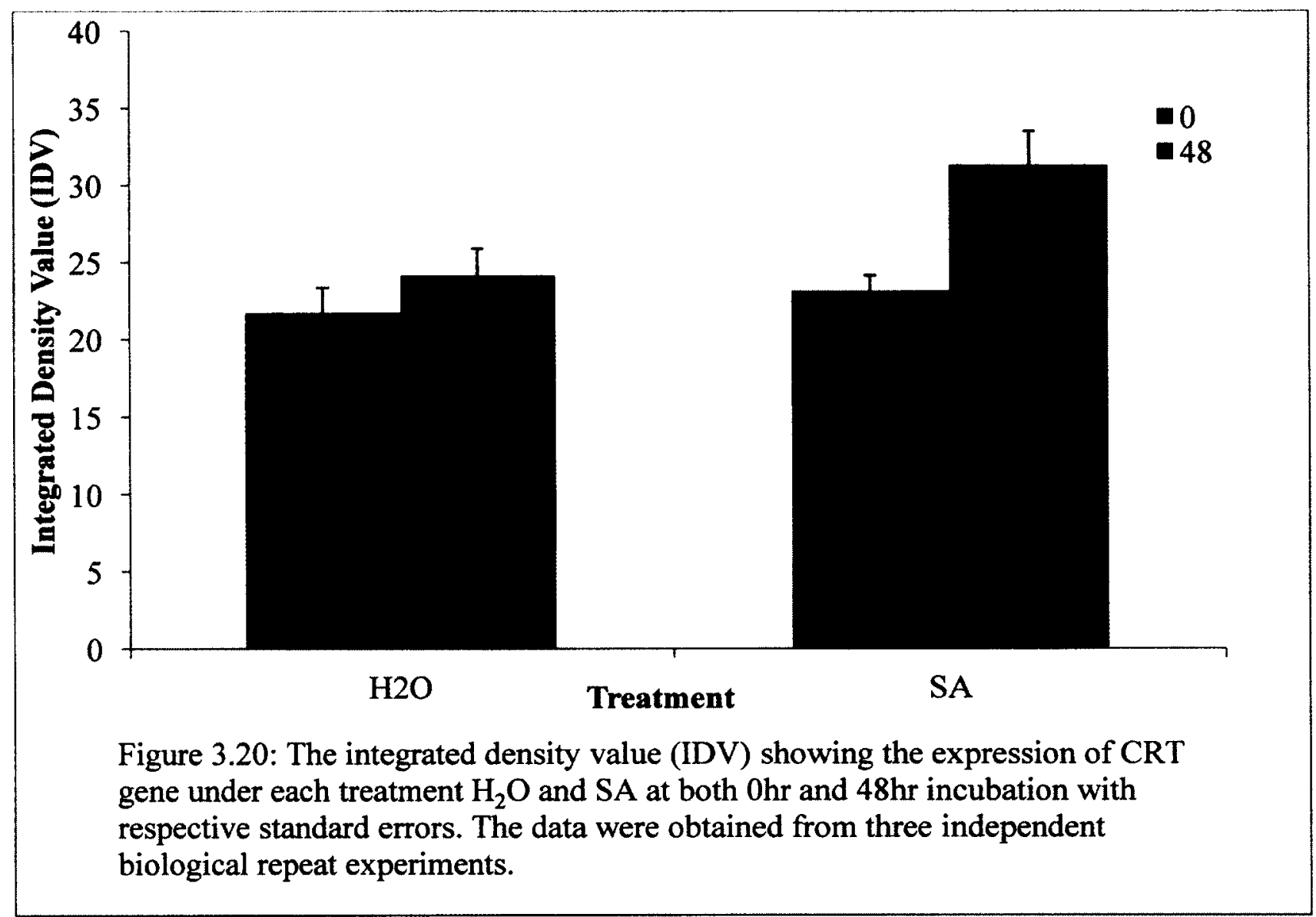

\subsection{Cloning CRT gene into $\mathrm{pET} 14 \mathrm{~b}$ vector}

\subsubsection{Producing the blunt-end PCR products}

Figure 3.21 shows the $50 \mu \mathrm{L}$ PCR reaction prepared to amplify CRT using high-fidelity Pfx DNA polymerase and cDNA of $0 \mathrm{~h}$ water treatment of $2390.4 \mathrm{ng} / \mu \mathrm{L}$ concentration. Also shown is the recovery of CRT after gene clean using the Wizard® SV Gel and PCR Clean-Up System. 


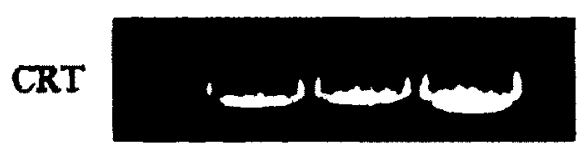

(A)
CRT

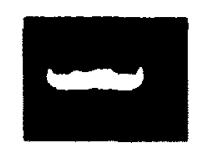

(B)

Figure 3.21: (A) Amplification of CRT by Pfx polymerase enzyme. (B) The recovery of CRT gene in (A) after gene clean by Wizard® SV Gel and PCR Clean-Up System. Note that the three lanes in (A) are the same reaction loaded as such because of the limited gel volume capacity.

The control template gene provided by the zero blunt TOPO cloning kit for sequencing is presented in Figure 3.22 along with its recovery after gene clean using Wizard® SV Gel and PCR Clean-Up System.

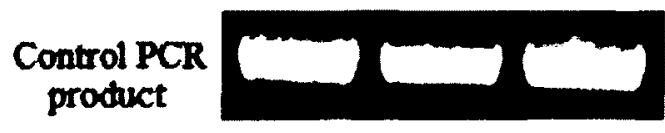

(A)

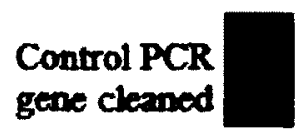

(B)

Figure 3.22: (A) The expression of control PCR product amplified by $P f x$ polymerase enzyme and (B) the recovery of that control product after gene clean by Wizard® SV Gel and PCR Clean-Up System.

\subsubsection{Cloning into TOPO vector}

Figure 3.23 shows the $15 \mu \mathrm{L}$ and $45 \mu \mathrm{L}$ transformations of the TOPO reaction as well as the control reactions spread on pre-warmed $50 \mu \mathrm{g} / \mathrm{mL}$ kanamycin selective plates. Relatively few colonies (less than $5 \%$ of foreground) were produced in the vector-only reactions (Figure $3.23 \mathrm{~A}$ and $\mathrm{B})$. More than 100 colonies were produced in the transforming vector and PCR control insert (Figure $3.23 \mathrm{C}$ and D). Among these colonies $95 \%$ were expected to have the $750 \mathrm{bp}$ control 
insert when analyzed. Colonies were also produced in the transforming vector with CRT insert (Figure $3.23 \mathrm{E}$ and $\mathrm{F}$ ).

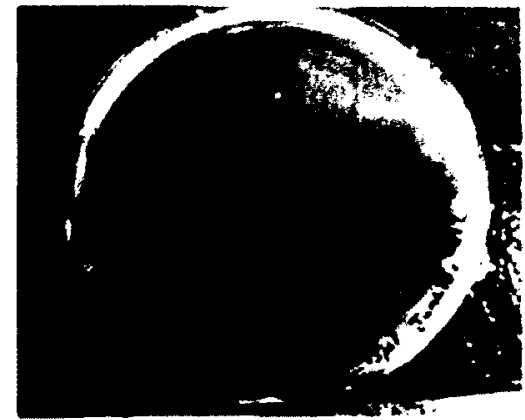

(A)

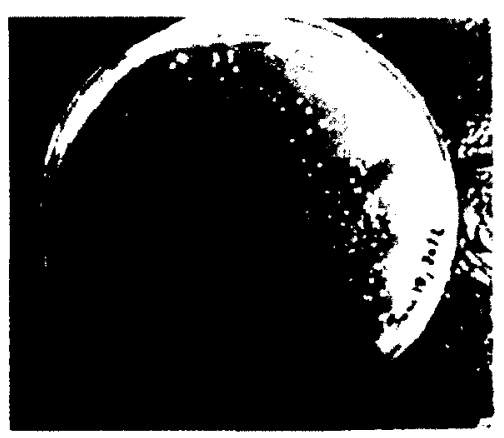

(C)

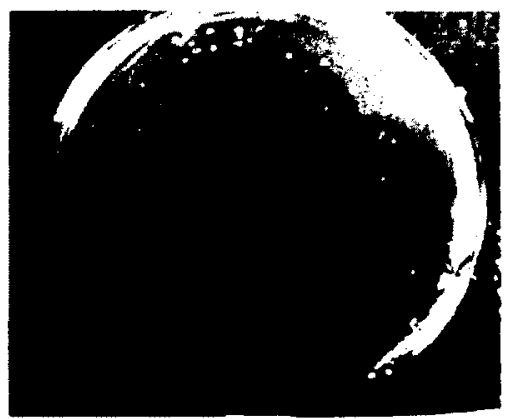

())

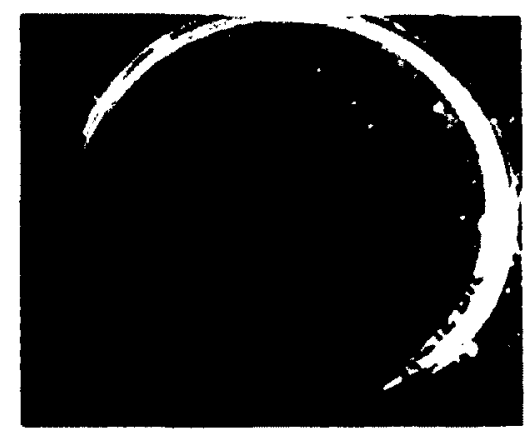

(B)

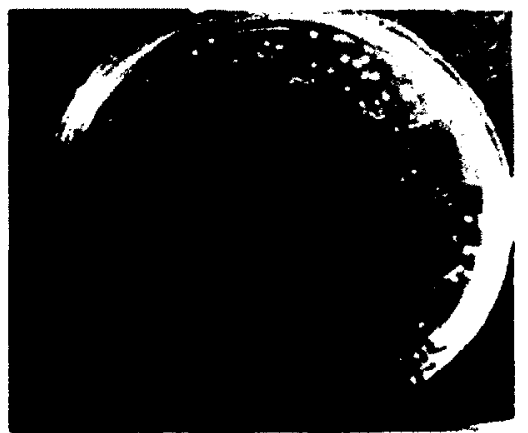

(D)

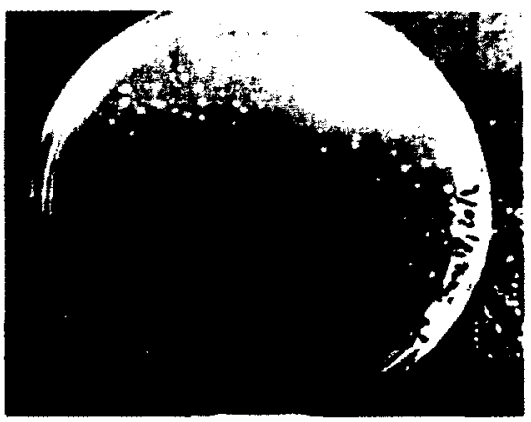

(F)

Figure 3.23: Transformation of TOPO reactions in Mach $1^{\mathrm{TM}}-\mathrm{T} 1^{\mathrm{R}}$ cells plated on LB medium with $50 \mu \mathrm{g} / \mathrm{mL}$ kanamycin antibiotic. (A), (B) are $15 \mu \mathrm{L}$ and $45 \mu \mathrm{L}$ respectively of the TOPO transforming vector alone. (C), (D) are $15 \mu \mathrm{L}$ and $45 \mu \mathrm{L}$ respectively of transforming vector and PCR control insert. (E), (F) are $15 \mu \mathrm{L}$ and $45 \mu \mathrm{L}$ respectively of transforming the vector and CRT insert. 
Amplification of CRT gene after cloning into TOPO vector and recovering by plasmid preparation showed high intensity of the bands (Figure 3.24). Table 3.3 shows the concentrations of the colonies recovered by plasmid preparation.

CRT

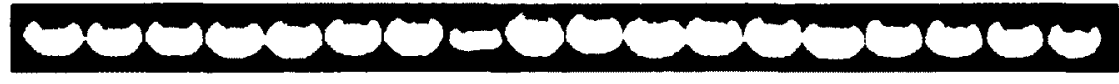

Figure 3.24: Amplification of CRT2 gene after cloning into TOPO vector and recovering by plasmid prep. Each lane represents a different single colony.

Table 3.3: The concentrations $(\mathrm{ng} / \mu \mathrm{L})$ of the TOPO plasmids containing CRT gene inserts.

\begin{tabular}{|c|c|c|c|}
\hline Sample & $\begin{array}{c}\text { Concentration (ng/ } \\
\boldsymbol{\mu L})\end{array}$ & Sample & $\begin{array}{c}\text { Concentration (ng/ } \\
\boldsymbol{\mu L} \text { ) }\end{array}$ \\
\hline $\mathbf{1}$ & $\mathbf{8 2 . 2 0}$ & $\mathbf{1 0}$ & 171.4 \\
\hline $\mathbf{2}$ & 145.0 & $\mathbf{1 1}$ & 162.6 \\
\hline $\mathbf{3}$ & 146.4 & $\mathbf{1 2}$ & 153.9 \\
\hline $\mathbf{4}$ & 163.9 & $\mathbf{1 3}$ & 142.2 \\
\hline $\mathbf{5}$ & 163.2 & $\mathbf{1 4}$ & 36.70 \\
\hline $\mathbf{6}$ & 166.4 & $\mathbf{1 5}$ & 148.7 \\
\hline $\mathbf{8}$ & 175.1 & $\mathbf{1 6}$ & 171.9 \\
\hline $\mathbf{9}$ & 93.50 & $\mathbf{1 7}$ & 178.5 \\
\hline & 178.8 & $\mathbf{1 8}$ & $\mathbf{8 8 . 3 0}$ \\
\hline
\end{tabular}

\subsubsection{Digesting the insert and pET14b vector to produce the sticky (cohesive) ends}

\subsubsection{Double digestion of CRT insert}

From Table 3.3, sample 7 of undigested plasmid with CRT insert $(175.1 \mathrm{ng} / \mu \mathrm{L})$ was used. $3 \mu \mathrm{g}$ of the sample was needed to carry out the digestion. So: 
Concentration $=$ mass $/$ volume $\rightarrow\left(175.1 \times 10^{-3} \mu \mathrm{g} / \mu \mathrm{L}\right)=3 \mu \mathrm{g} /$ volume $\rightarrow$ volume $=17.2 \mu \mathrm{L}$

Therefore $17.2 \mu \mathrm{L}$ of sample 7 were required to obtain $3 \mu \mathrm{g}$ of the insert. The double digested reaction was loaded on a $1 \%$ gel along with the uncut sample as control shown in Figure 3.25 below. The uncut plasmid shows 3 bands. Usually these bands would account for supercoiled, linear, and nicked or relaxed circular plasmid. However, due to the large sizes of the bands, they seem to be random dimer combinations. Comparing the uncut sample to the cut sample verifies that complete digestion took place.

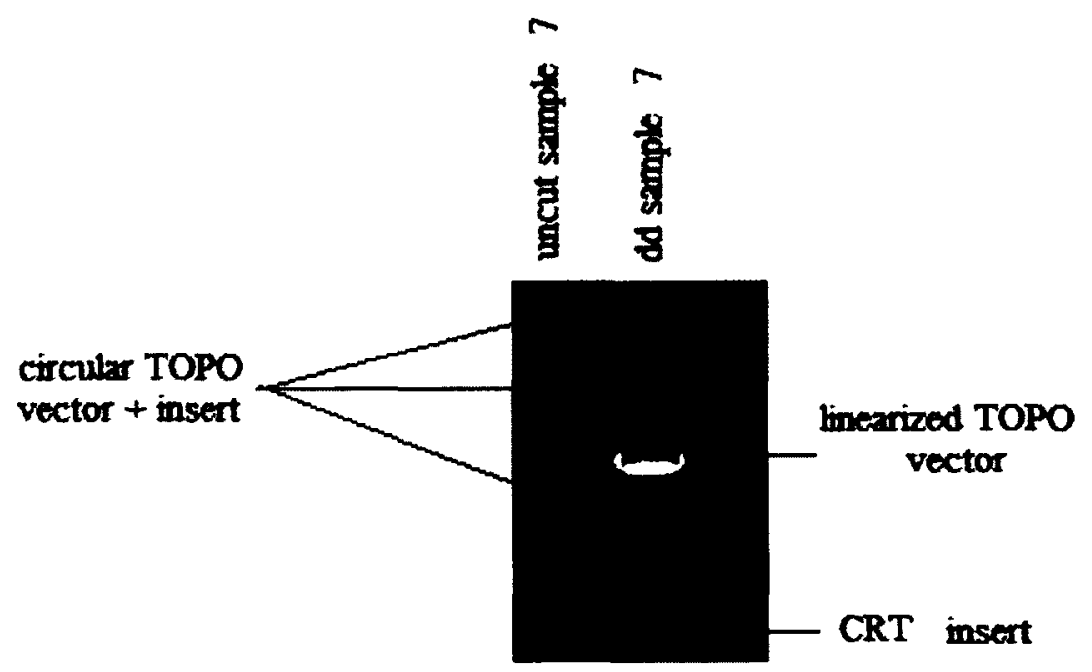

Figure 3.25: Undigested and double digested CRT insert and TOPO vector by NdeI and Xhol restriction enzymes.

The size of the double digested CRT insert was as expected and so CRT insert was gene cleaned. The concentration was measured by Nanodrop to be $9.5 \mathrm{ng} / \mu \mathrm{L}$. 


\subsubsection{Double digestion of $\mathrm{pET} 14 \mathrm{~b}$ vector}

$3 \mu \mathrm{g} \mathrm{pET14b} \mathrm{vector} \mathrm{was} \mathrm{directly} \mathrm{double} \mathrm{digested} \mathrm{without} \mathrm{being} \mathrm{transformed} \mathrm{in} \mathrm{any} \mathrm{cells.}$ $6 \mu \mathrm{L}$ of $0.5 \mu \mathrm{g} / \mu \mathrm{L}$ pET14b vector was digested with NdeI enzyme and $3 \mu \mathrm{L}$ of the sample was run on a $0.8 \%$ gel as seen in Figure 3.26. The reaction was then digested with Xhol restriction enzyme and run on a $0.8 \%$ gel as seen in Figure 3.27. Figure 3.28 shows the double digested pET14b vector loaded on a $1 \%$ gel after the addition of 0.05 units/pmol calf-intestinal alkaline phosphatase (CIAP). After the pET14b vector was gene cleaned the concentration was measured by Nanodrop to be $25.8 \mathrm{ng} / \mu \mathrm{L}$.

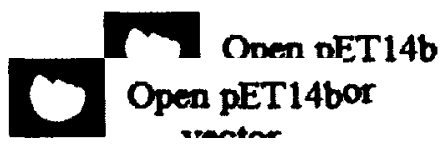

Figure 3.26: Digested pET14b vector with NdeI restriction enzyme for $2 \mathrm{hr}$ at $37^{\circ} \mathrm{C}$.

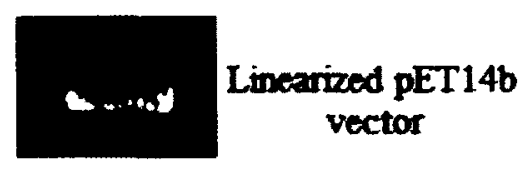

Figure 3.27: Double digested $\mathrm{pET14b}$ vector with NdeI and Xhol restriction enzymes before the addition of CIAP enzyme.

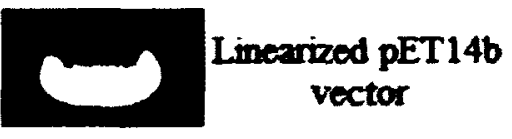

Figure 3.28: Double digested $\mathrm{pET14b}$ vector with NdeI and Xhol restriction enzymes after the addition of CIAP enzyme. 


\subsubsection{Ligating the double digested CRT insert and pET14b vector}

In order to ligate the insert and vector, the amount used of each was determined based on concentrations and the required insert to vector ratio. The following equation was used to determine the amounts of insert and vector used:

[(ng of vector) $\times(\mathrm{Kb}$ size of insert) $/(\mathrm{Kb}$ size of vector $)] \times($ molar ratio of insert to vector $)=\mathrm{ng}$ of insert

In the equation the mass of vector $(\mathrm{ng})=$ (concentration of vector) (volume of vector) and the mass of insert $(\mathrm{ng})=$ (concentration of insert) (volume of insert). The volume of the vector is denoted " $\mathrm{X}$ " while that of the insert is "Y" where $\mathrm{X}+\mathrm{Y}=8 \mu \mathrm{L}$. The size of the vector is $4664 \mathrm{bps}$ and that of the insert is $1143 \mathrm{bps}$.

Two ligations were prepared with the same vector and insert but at different vector to insert ratios. The first ligation was 1:3 while the other was 1:1.

\subsubsection{Ligation 1, $1: 3$ vector to insert ratio}

$$
\begin{gathered}
{[(25.8 \mathrm{X})(1143 \mathrm{bps}) / 4664 \mathrm{bps}][3 / 1]=9.5 \mathrm{Y}} \\
88,468.2 \mathrm{X}-44,308 \mathrm{Y}=0
\end{gathered}
$$

Now that there are 2 equations and 2 unknowns, $\mathrm{X}$ and $\mathrm{Y}$ were calculated to be 2.7 and 5.3 respectively.

Therefore $2.7 \mu \mathrm{L}$ of the pET14b vector and $5.3 \mu \mathrm{L}$ of the CRT insert were added to $1.5 \mu \mathrm{L}$ 10X ligase buffer and $0.5 \mu \mathrm{L}$ T4 DNA ligase enzyme for a $10 \mu \mathrm{L}$ total reaction. 
$15 \mu \mathrm{L}$ and $50 \mu \mathrm{L}$ volumes of ligation 1 transformed into BL21 cells plated on LB media containing $100 \mu \mathrm{g} / \mathrm{mL}$ ampicillin antibiotic are shown in Figure 3.29. The colonies were distant and large in both plates.
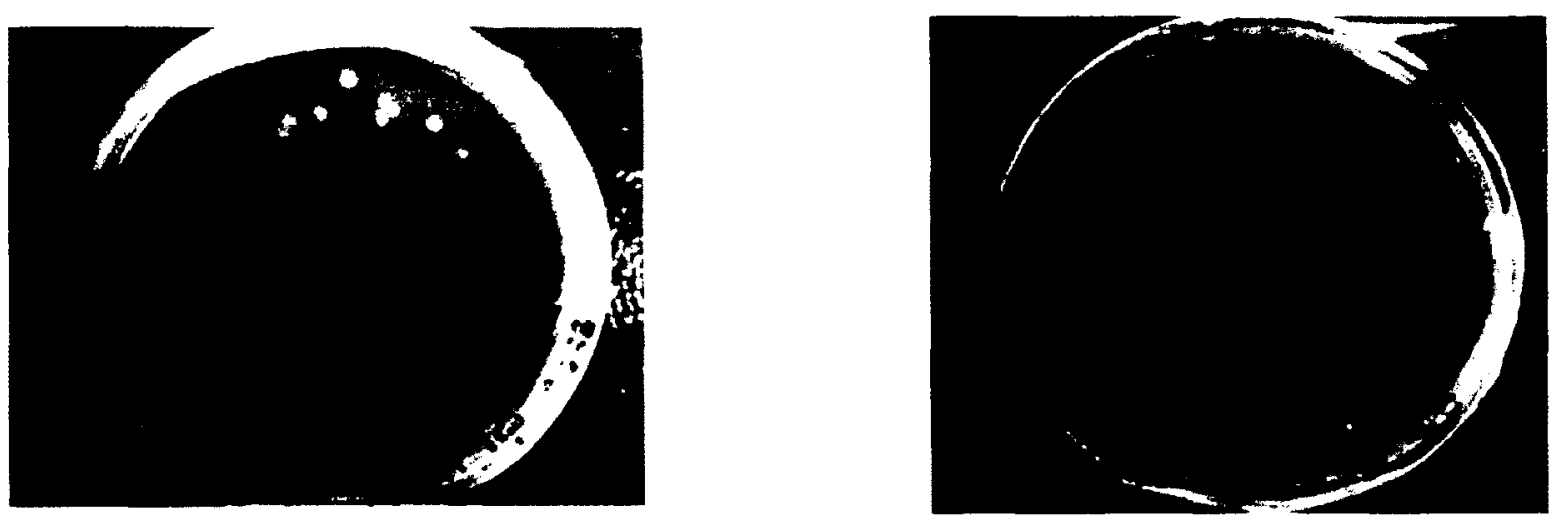

Figure 3.29: $15 \mu \mathrm{L}$ (left) and $50 \mu \mathrm{L}$ (right) plating of ligations 1 transformed in BL21 cells. Several colonies are seen in each plate with more in the $50 \mu \mathrm{L}$ plate than the $15 \mu \mathrm{L}$ plate.

\subsubsection{Ligation 2, 1:1 vector to insert ratio}

$$
\begin{gathered}
{[(25.8 \mathrm{X})(1143 \mathrm{bps}) / 4664 \mathrm{bps}][1 / 1]=9.5 \mathrm{Y}} \\
29,489.4 \mathrm{X}-44,308 \mathrm{Y}=0
\end{gathered}
$$

Similarly using the 2 equations and 2 unknowns, $\mathrm{X}$ and $\mathrm{Y}$ were calculated to be 4.8 and 3.2 respectively.

Therefore $4.8 \mu \mathrm{L}$ of the pET14b vector and $3.2 \mu \mathrm{L}$ of the CRT insert were added to $1.5 \mu \mathrm{L}$ 10X ligase buffer and $0.5 \mu \mathrm{L}$ T4 DNA ligase enzyme for a $10 \mu \mathrm{L}$ total reaction. 
$15 \mu \mathrm{L}$ and $50 \mu \mathrm{L}$ volumes of ligation 2 transformed into BL21 cells plated on LB media containing $100 \mu \mathrm{g} / \mathrm{mL}$ ampicillin antibiotic are shown in Figure 3.30. The colonies were distant and large in both plates.
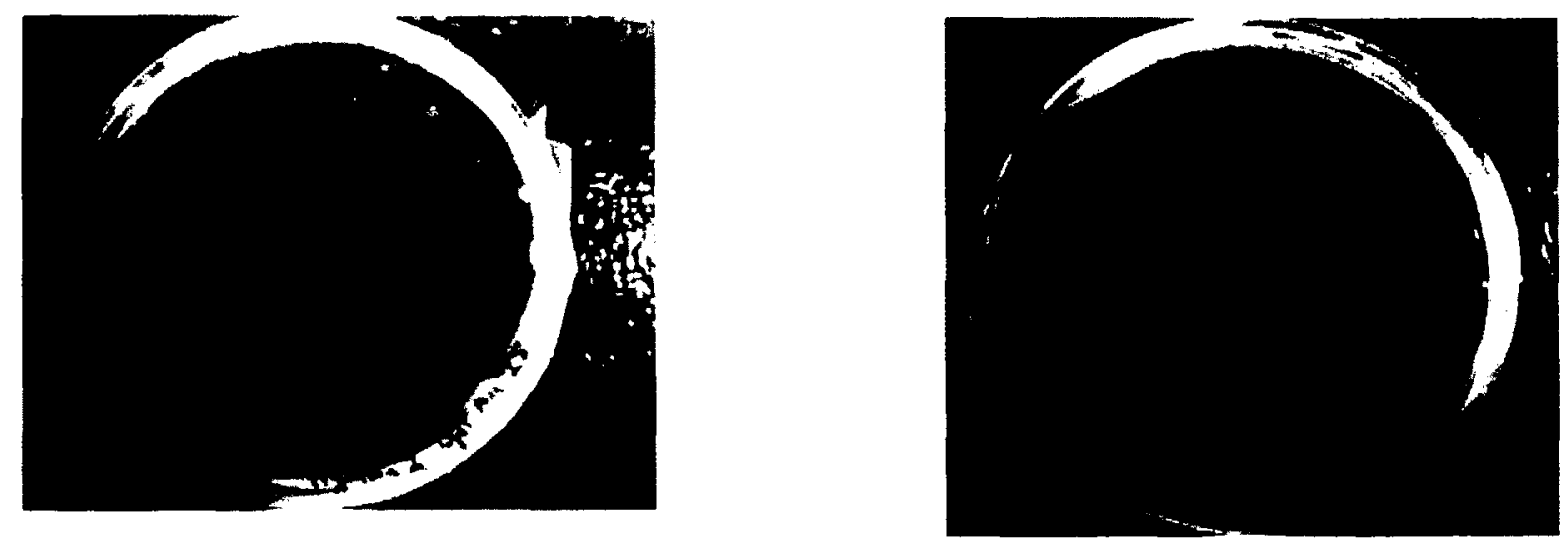

Figure 3.30: $15 \mu \mathrm{L}$ (left) and $50 \mu \mathrm{L}$ (right) plating of ligations 2 transformed in BL21 cells. More colonies are seen in the $50 \mu \mathrm{L}$ plate than the $15 \mu \mathrm{L}$ one.

\subsubsection{Control reactions}

Control reaction 1 with no insert showed very few colonies in both plates. These colonies are due to the ligation of the vector on itself. Control reaction 2 with no vector showed no colonies at all (Figure 3.31). 

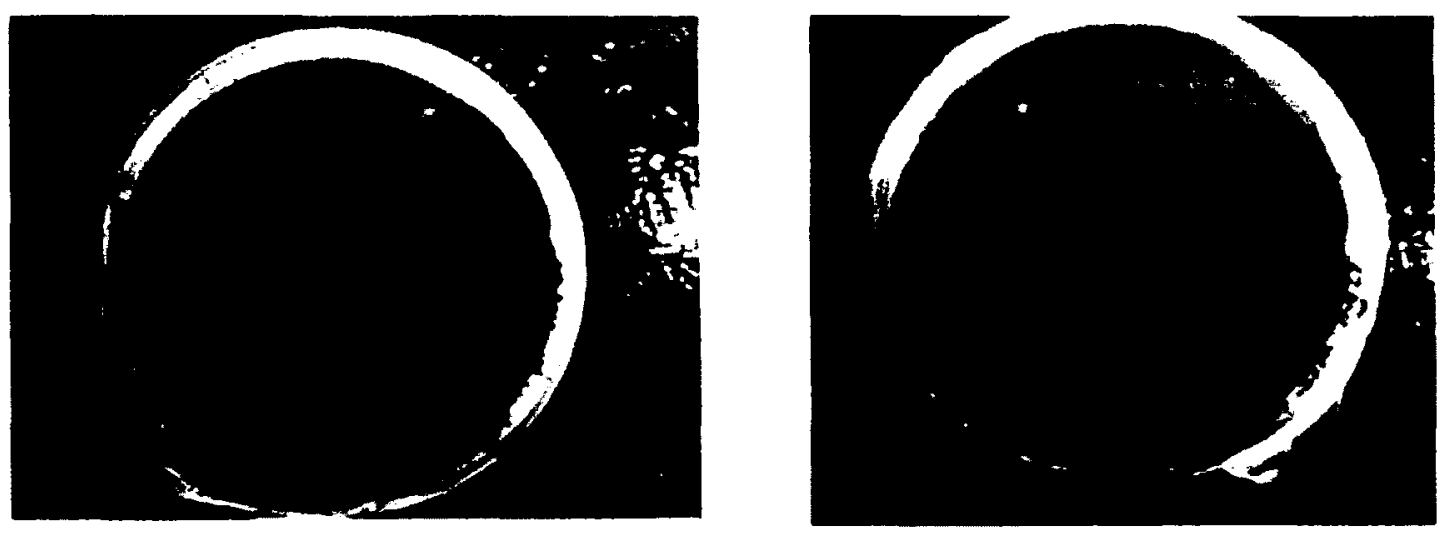

(A)
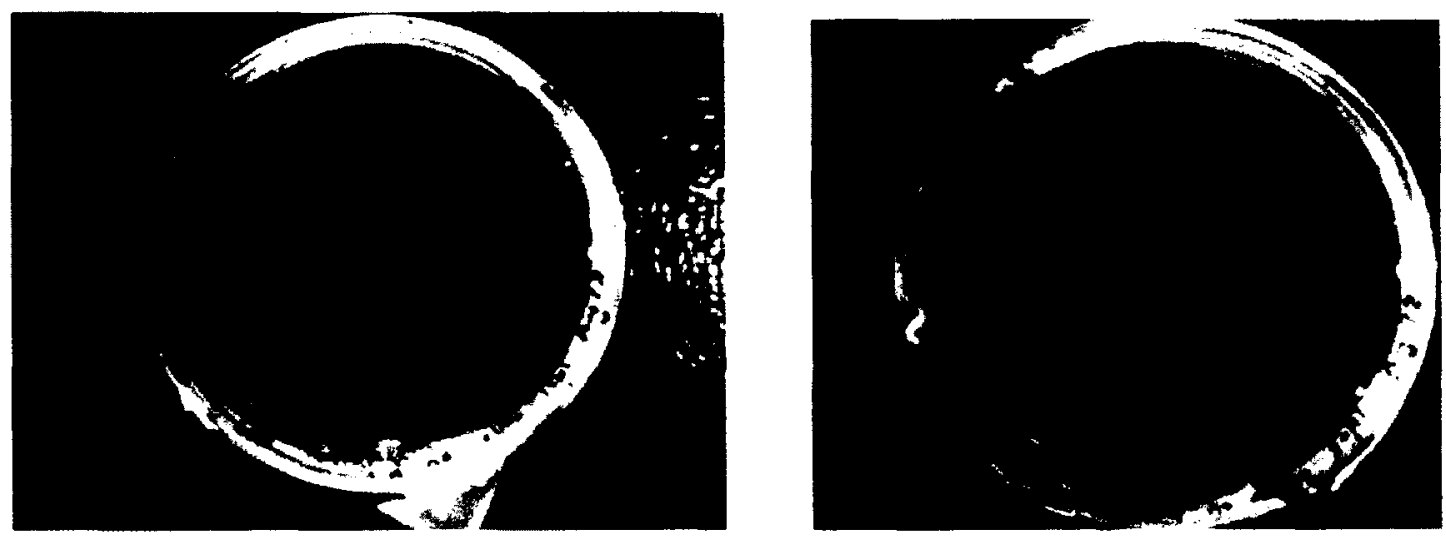

(B)

Figure 3.31: $15 \mu \mathrm{L}$ and $50 \mu \mathrm{L}$ platting of controls 1 and 2 of ligation 1 . (A) Control 1 with no insert showed four colonies only. (B) Control 2 with no vector showed no colonies in either volume.

\subsubsection{Transformation efficiency of BL21 cells}

The transformation efficiency was expected to be at least $2 \times 10^{6} \mathrm{cfu} / \mu \mathrm{g}$ test plasmid DNA. The transformation efficiency was calculated as follows:

$$
\frac{10}{10 \mathrm{pg} \text { transformed DNA }} \times \frac{100 \mathrm{pg}}{\mu \mathrm{g}} \times \frac{\begin{array}{c}
300 \mu \mathrm{\mu l} \text { total } \\
\text { transformation volume }
\end{array}}{\mathrm{X \mu l} \text { plated }}=\frac{\text { transformants }}{\mu \mathrm{g} \text { plasmid DNA }}
$$


$(820$ colonies $/ 10 \mathrm{pg}) \times\left(10^{6} \mathrm{pg} / \mu \mathrm{g}\right) \times(300 \mu \mathrm{L} / 10 \mu \mathrm{L})=2.46 \times 10^{9} \mathrm{cfu} / \mu \mathrm{g}$ test plasmid DNA.

As this value is greater than $2 \times 10^{6} \mathrm{cfu} / \mu \mathrm{g}$ DNA, it is safe to say that the transformation efficiency is high (Figure 3.32).

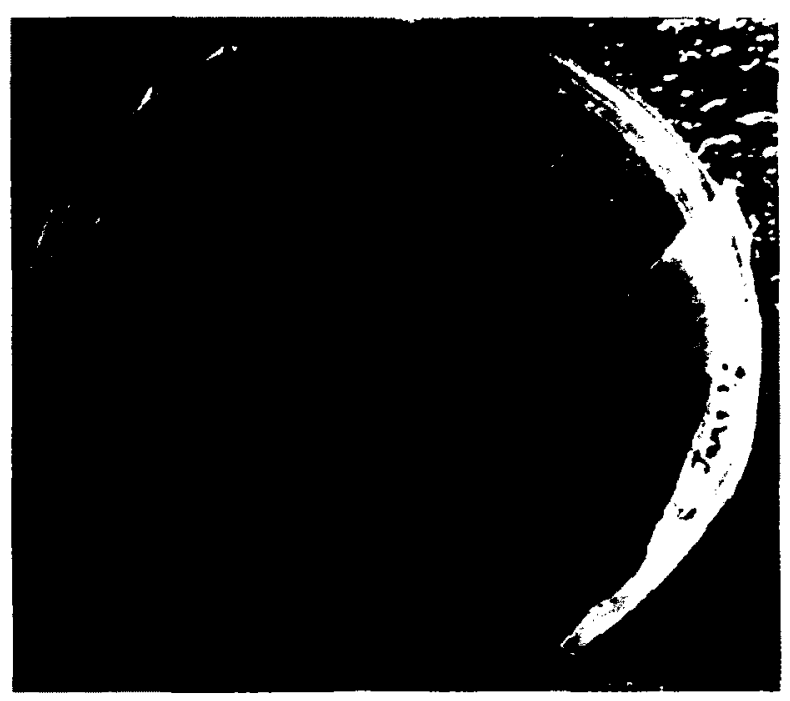

Figure 3.32: The transformation effeciency of BL21 competent cells determined using pUC18 test plasmid.

\subsubsection{Checking for the correct orientation}

Typically the insert would be ligated in the vector in the correct orientation, however that is not always the case since sometimes the insert ligates in the wrong orientations to the vector. In order to check if the insert was ligated in the correct orientation, several tests were conducted. 10 colonies of each ligation were picked for plasmid preparation and the concentration of each sample was measured via Nanodrop (Table 3.4). 
Table 3.4: The concentration $(\mathrm{ng} / \mu \mathrm{L})$ of the ligated $\mathrm{CRT}$ insert and $\mathrm{pET} 14 \mathrm{~b}$ vector recovered by plasmid preparation.

\begin{tabular}{|c|c|c|c|}
\hline Sample & $\begin{array}{c}\text { Concentration (ng/ } \\
\boldsymbol{\mu L} \text { ) }\end{array}$ & Sample & $\begin{array}{c}\text { Concentration (ng/ } \\
\boldsymbol{\mu L} \text { ) }\end{array}$ \\
\hline $\mathbf{1}$ & 23.5 & 11 & 37.3 \\
\hline $\mathbf{2}$ & 27.2 & $\mathbf{1 2}$ & 31.7 \\
\hline $\mathbf{3}$ & 28.2 & $\mathbf{1 3}$ & 22.0 \\
\hline $\mathbf{5}$ & 29.1 & $\mathbf{1 4}$ & 21.3 \\
\hline $\mathbf{6}$ & 19.9 & 15 & 32.6 \\
\hline $\mathbf{7}$ & 20.1 & $\mathbf{1 6}$ & 40.9 \\
\hline $\mathbf{8}$ & 30.5 & 17 & 32.0 \\
\hline $\mathbf{9}$ & 29.9 & $\mathbf{1 8}$ & 34.9 \\
\hline 10 & 33.9 & $\mathbf{1 9}$ & 42.0 \\
\hline
\end{tabular}

* Sample 10 was a bad sample and was therefore discarded.

\subsubsection{Using PCR}

In order to carry out this test, PCR was conducted by using one primer for $\mathrm{pET} 14 \mathrm{~b}$ vector and the other primer for CRT insert. A positive reaction would yield a band at around $1300 \mathrm{bp}$ while a negative reaction will give several undefined bands (Figures 3.33 and 3.34 respectively).

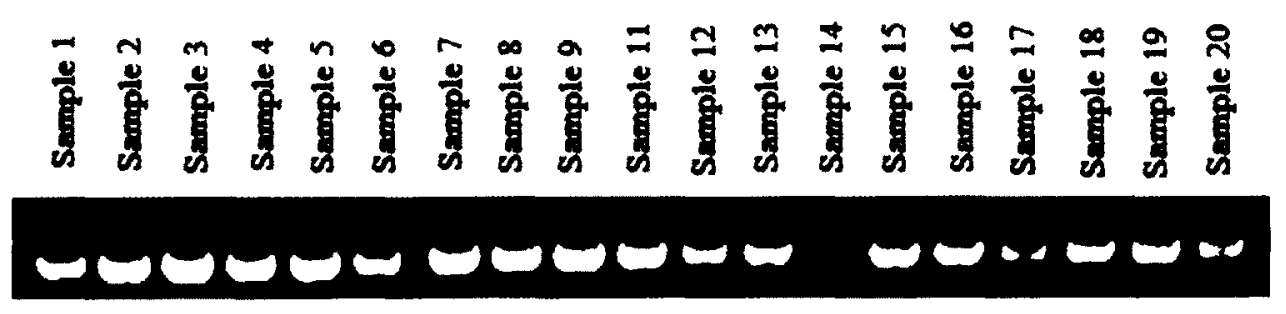

Figure 3.33: Positive PCR reactions to check for the correct orientation of the CRT insert ligated in pET14b plasmid. The band obtained from each sample is of the correct and expected size. 


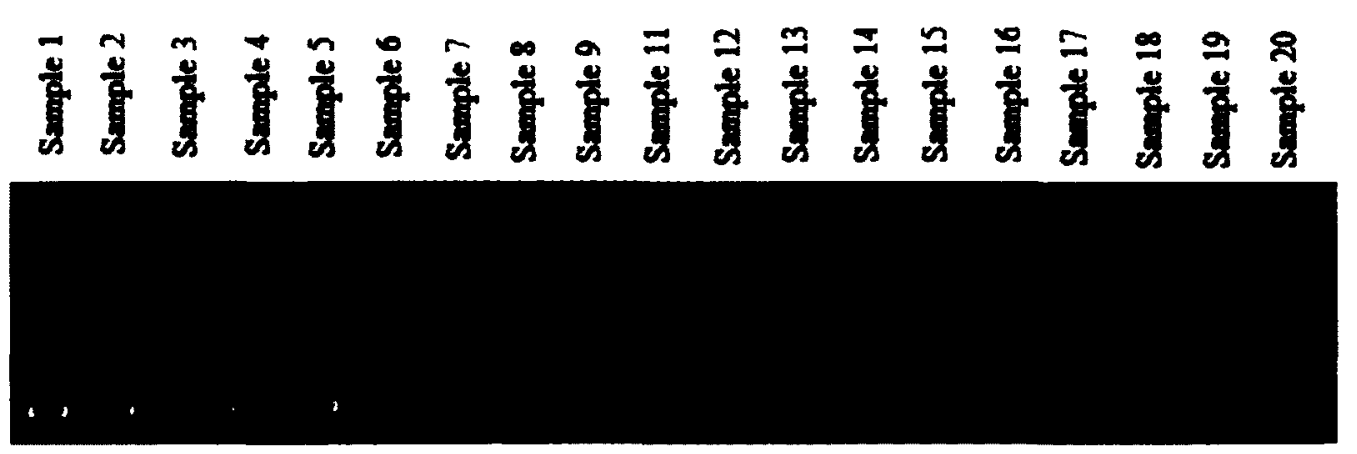

Figure 3.34: Negative PCR reactions to check the orientation of the CRT insert ligated in the $\mathrm{pET} 14 \mathrm{~b}$ vector. The random irregular bands obtained are expected.

\subsubsection{Using restriction enzyme NcoI}

Five samples $(9,11,16,18$ and 19 from Table 3.4) with the highest concentrations were selected to undergo a single digestion with Ncol restriction enzyme. This enzyme was chosen because it has one cutting site in each of the vector and insert and because the sizes of the bands obtained in the correct and wrong orientations are very distinguishable. Together the vector and insert are 5814bps in size taking into consideration the restriction sites. If the ligation were in the correct orientation, a small band of $850 \mathrm{bps}$ and a larger one of $4964 \mathrm{bps}$ in size were expected to be obtained. However if the ligation were in the wrong orientation, a small band of $416 \mathrm{bps}$ and a larger one of $5398 \mathrm{bps}$ in size were expected to be obtained. The reactions were loaded on a $0.8 \%$ gel as shown in Figure 3.35. 


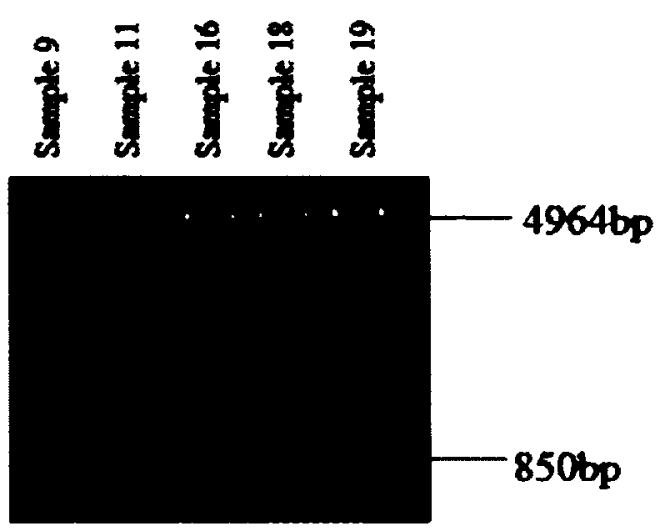

Figure 3.35: 850bps small band and 4964bps large band obtained by digestion with NcoI restriction enzyme confirming that the insert and vector are ligated in the correct orientation.

\subsection{Expressing the target gene}

Sample 19 from Table $3.4(42.0 \mathrm{ng} / \mu \mathrm{L})$ was used in order to express the target gene.

\subsubsection{Expression host transformation}

$150 \mu \mathrm{L}$ and $200 \mu \mathrm{L}$ volumes of the target gene transformed into BL21-CodonPlus (DE3)RIPL competent cells were platted on $100 \mu \mathrm{g} / \mathrm{mL}$ carbenicillin and $30 \mu \mathrm{g} / \mathrm{mL}$ chloramphenicol LB plates. Both plates showed many colonies some of which are isolated (Figure 3.36). 

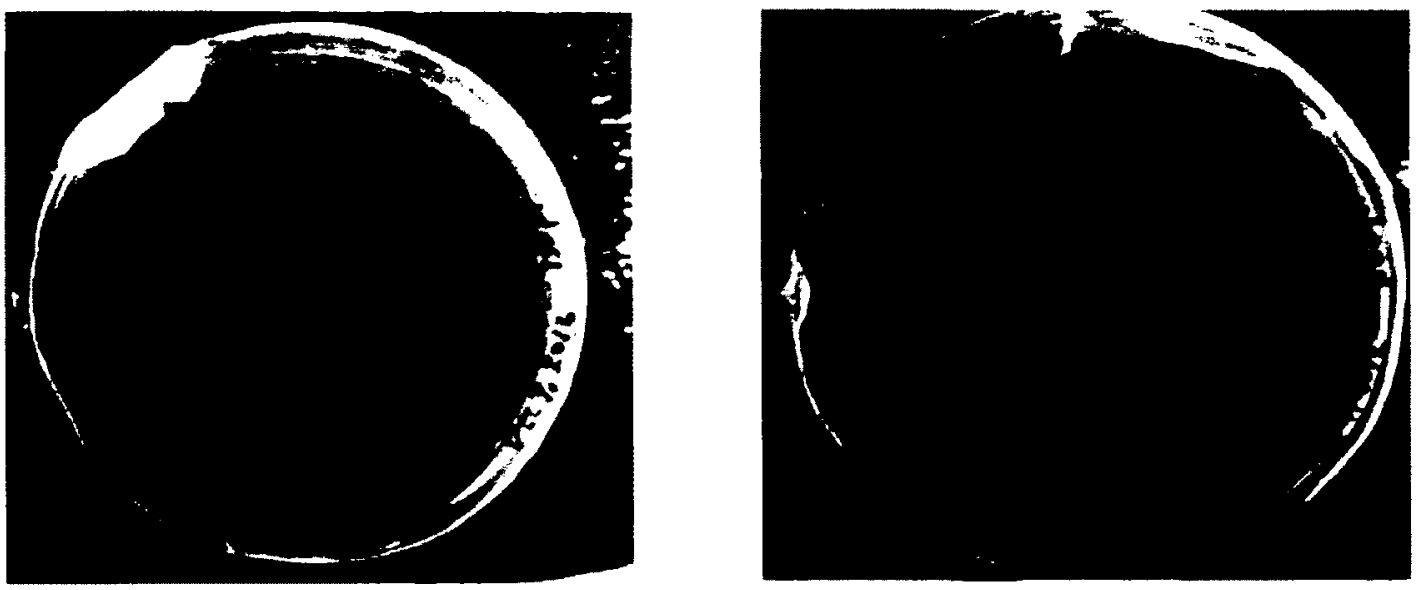

Figure 3.36: Plating of $150 \mu \mathrm{L}$ and $200 \mu \mathrm{L}$ of the target gene transformed into BL21-CodonPlus (DE3)-RIPL competent cells on $100 \mu \mathrm{g} / \mathrm{mL}$ carbenicillin and $30 \mu \mathrm{g} / \mathrm{mL}$ chloramphenicol LB plates. Many colonies are observed.

\subsubsection{Determination of the culture $\mathrm{OD}_{600}$ at harvest}

Before induction, the culture was grown till $\mathrm{OD}_{600}=0.899$. After induction, $\mathrm{OD}_{600}$ was measured until the diluted reading was between 0.1 and 0.8 . The same was done for the uninduced culture. Table 3.5 below shows $\mathrm{OD}_{600}$ of the diluted cultures in order to determine $\mathrm{OD}_{600}$ at harvest.

Table 3.5: Determination of $\mathrm{OD}_{600}$ at harvest for both the induced and uninduced cultures.

\begin{tabular}{|c|c|c|c|}
\hline & $\begin{array}{c}\text { Dilution Factor } \\
\text { (DF) }\end{array}$ & $\begin{array}{c}\text { OD }_{600} \text { of diluted } \\
\text { sample }\end{array}$ & $\begin{array}{c}\text { OD }_{600} \text { at harvest } \\
\text { (DF x OD } \\
\text { sample })\end{array}$ \\
\hline Induced Culture & $5.0 \mathrm{X}$ & 0.464 & 2.320 \\
\hline Uninduced Culture & $8.2 \mathrm{X}$ & 0.721 & 5.912 \\
\hline
\end{tabular}




\subsubsection{Normalized SDS-PAGE gel}

Table 3.6 below shows the calculation for determination of the normalized volume of sample to load on a 10-well SDS-PAGE gel. The sample concentration factor represents the volume of original culture used to produce the fraction divided by the final volume of the fraction. For example for induced sample TCP, $1 \mathrm{~mL}$ of culture is used to prepare the fraction and after processing the final volume is $100 \mu \mathrm{L}$. The sample concentration factor is then $10(1000 \mu \mathrm{L} /$ $100 \mu \mathrm{L})$.

Table 3.6: Determination of the normalized volume of sample to load on a 10-well SDS-PAGE gel.

\begin{tabular}{|c|c|c|c|c|}
\hline & $\begin{array}{c}\text { Sample } \\
\text { concentration } \\
\text { factor }\end{array}$ & $\begin{array}{c}\text { OD } \\
\text { harvest }\end{array}$ & $\begin{array}{c}\mathrm{Z} \\
\text { (concentration factor } \mathrm{x} \\
\left.\mathrm{OD}_{600}\right)\end{array}$ & $\begin{array}{c}\text { Volume to } \\
\text { load }(\mu \mathrm{L}) \\
(270 \mu \mathrm{L} \div \mathrm{Z})\end{array}$ \\
\hline Total Cell Protein & $10.00 \mathrm{X}$ & 2.320 & & \\
\hline Medium & $10.00 \mathrm{X}$ & 2.320 & 23.20 & 11.64 \\
\hline $\begin{array}{c}\text { Soluble } \\
\text { Cytoplasminc }\end{array}$ & $41.80 \mathrm{X}$ & 2.320 & 23.20 & 11.64 \\
\hline Total Cell Protein & $10.00 \mathrm{X}$ & 5.912 & 96.97 & 2.780 \\
\hline Medium & $10.00 \mathrm{X}$ & 5.912 & & \\
\hline $\begin{array}{c}\text { Soluble } \\
\text { Cytoplasminc }\end{array}$ & $15.28 \mathrm{X}$ & 5.912 & 59.12 & 4.570 \\
\hline
\end{tabular}

\subsubsection{Detecting and quantifying target proteins}

\subsubsection{One dimensional SDS-PAGE}

Figure 3.37 shows the determination of protein expression by 15\% SDS-PAGE analysis of cell extracts followed by staining with Coomassie blue. As seen, the target CRT protein 
$(41.8 \mathrm{KDa})$ is shown as a unique more intense band when run adjacent to an uninduced extract. Proteins are separated according to size.

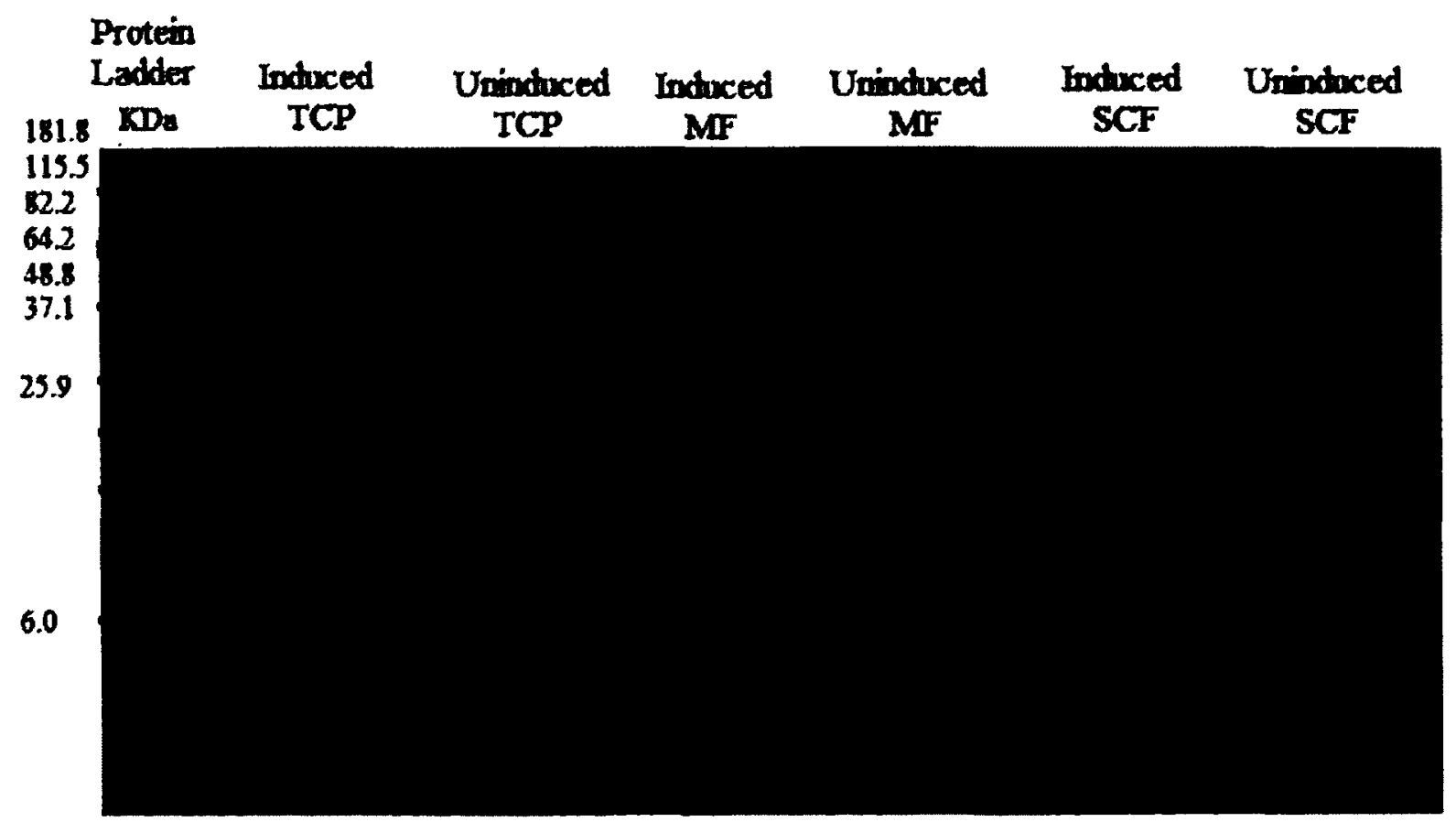

Figure 3.37: 15\% SDS-PAGE analysis of cell extracts followed by Coomassie blue staining showing a more intense band for CRT protein in the induced extract versus the uninduced. No proteins were detected in MF of either induced or uninduced extracts. TCP is total cell protein extract, MF is medium fraction extract, and SCF is soluble cytoplasmic extract.

Because bands 4 and 5 in the protein ladder of respective sizes $64.2 \mathrm{KDa}$ and $48.8 \mathrm{KDa}$ did not separate well and therefore the size of CRT target protein expected at $41.8 \mathrm{KDa}$ could not be determined, another SDS-PAGE gel was prepared at $10 \%$ for better separation (Figure 3.38). 


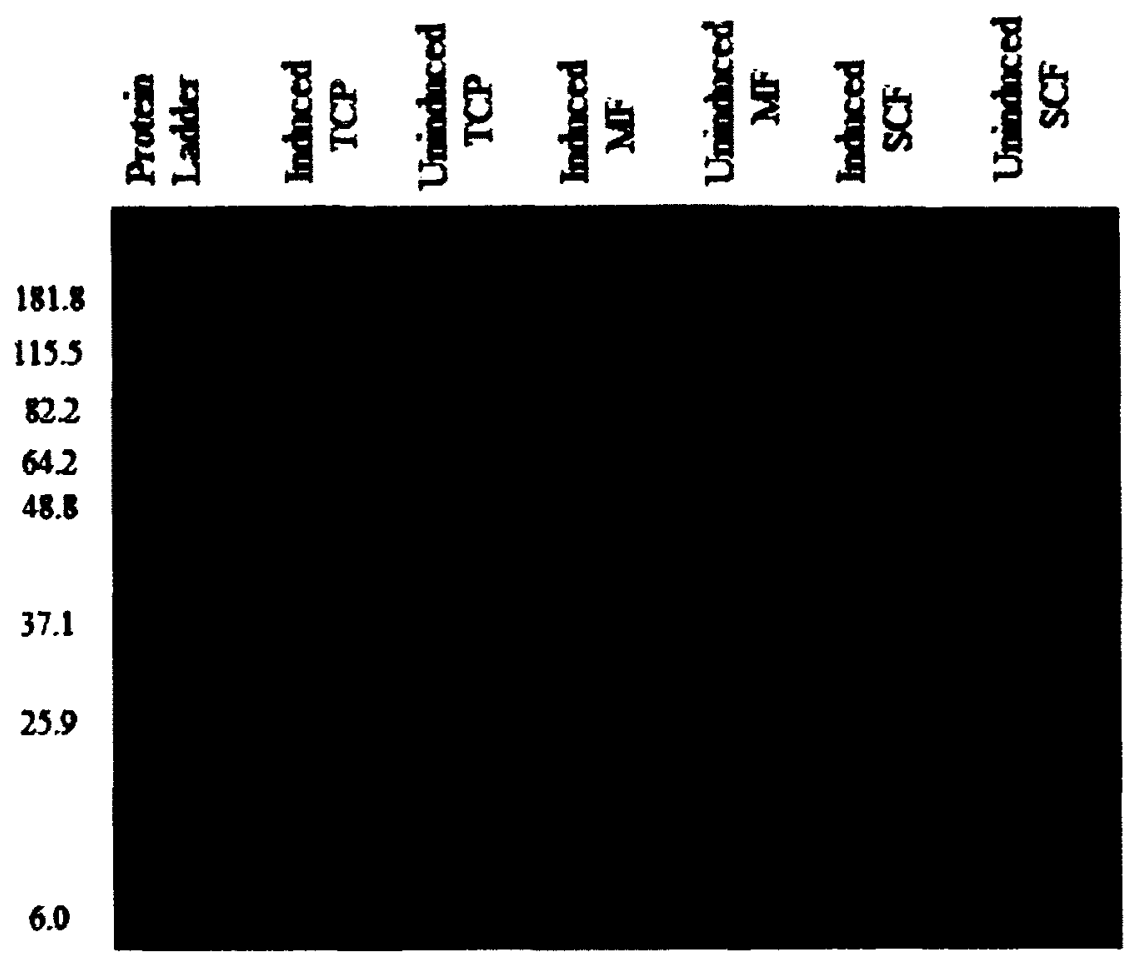

Figure 3.38: 10\% SDS-PAGE analysis of cell extracts followed by Coomassie blue staining showing a more intense band for $41.8 \mathrm{KDa}$ CRT protein in the induced extract versus the uninduced. No proteins were detected in MF of either induced or uninduced extracts.

\subsubsection{Immunoblotting and protein visualization}

Figure 3.39 shows the Western blot of the extracts visualized by enhanced chemiluminescence (ECL) system. Only proteins specific to the antibodies will illuminate. The Figure shows the target CRT protein also detected in SDS-PAGE gel. Other proteins of different sizes are also visible. 


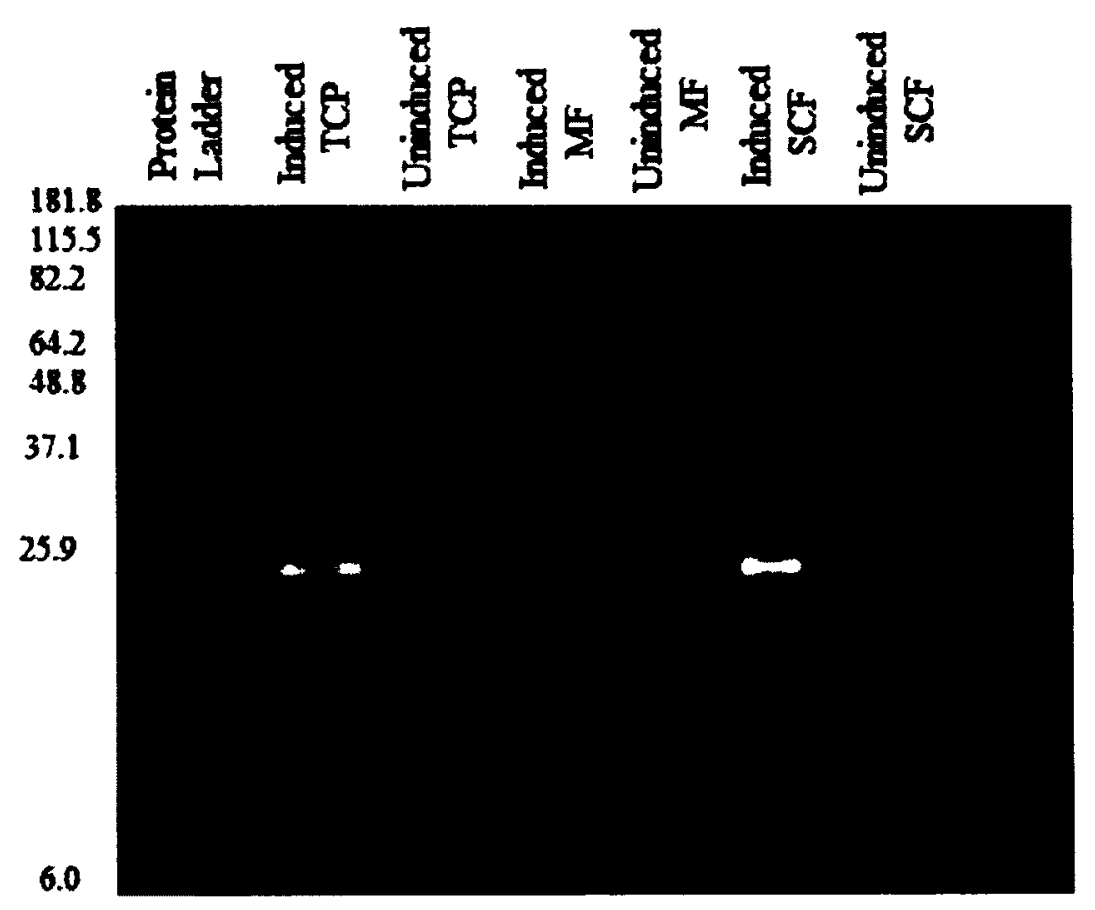

Figure 3.39: Immunoblotting of the extracts visualized by chemiluminescence (ECL) system. CRT protein is clearly visible as well as some other proteins of lower sizes.

\subsection{Enzyme analysis}

Two assays (glucanase and glutamine synthetase) were carried out for three treatments (at Ohr and 48hrs) against the water control. Protein extraction was done on leaves treated with $100 \mu \mathrm{M}$ salicylic acid, $5 \mu \mathrm{g} / \mathrm{mL}$ tunicamycin or $1 \mathrm{mM}$ dithiothreitol.

\subsubsection{Glucanase assay}

A higher activity than $0 \mathrm{hr} \mathrm{H}_{2} \mathrm{O}$ was observed in each of $0 \mathrm{hr}$ SA, TM and DTT. Contrarily, a lower activity than $48 \mathrm{hr} \mathrm{H}_{2} \mathrm{O}$ was observed in each of $48 \mathrm{hr}$ SA, TM and DTT (Figures 3.40, 3.41, and 3.42). 


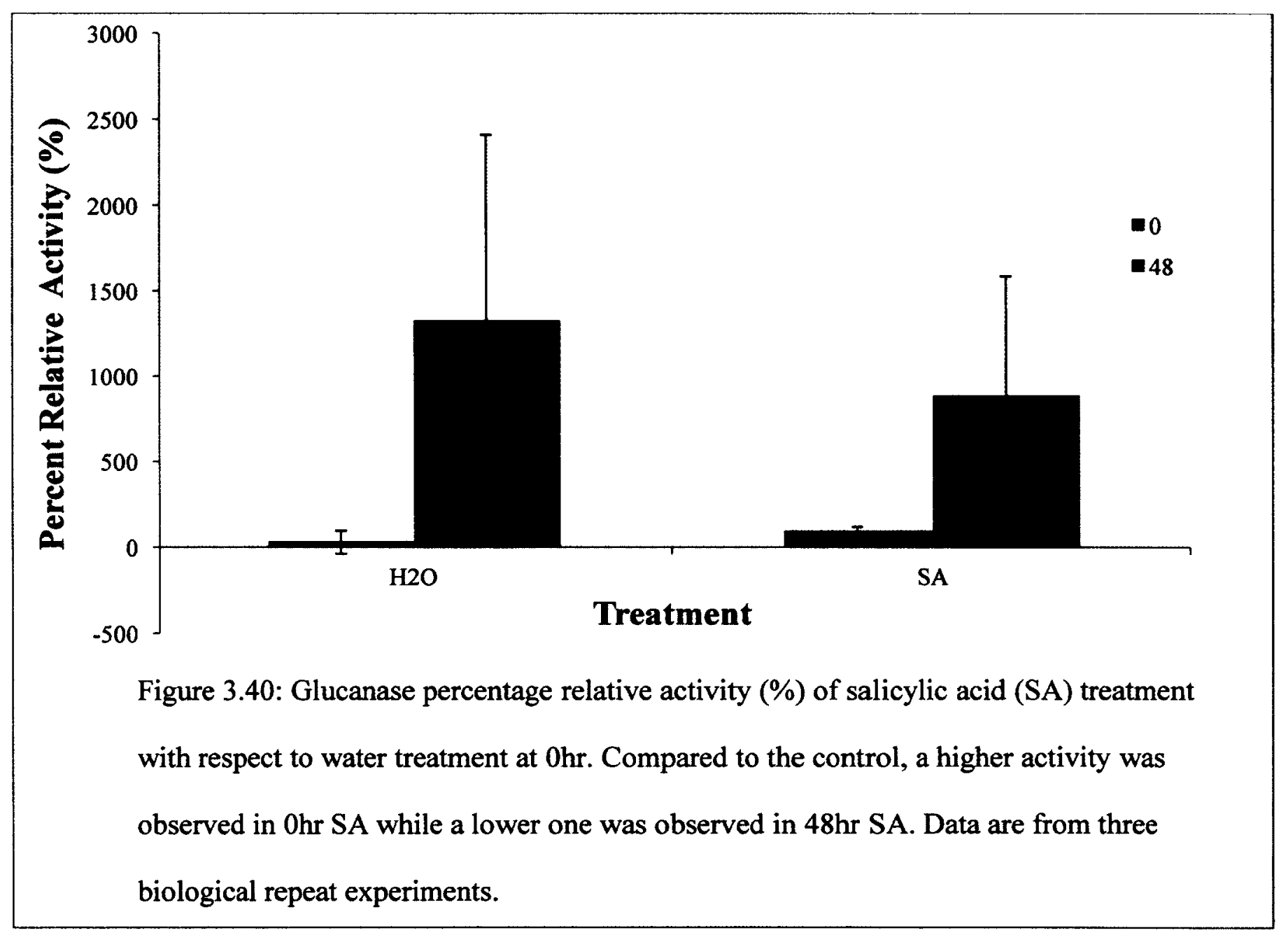




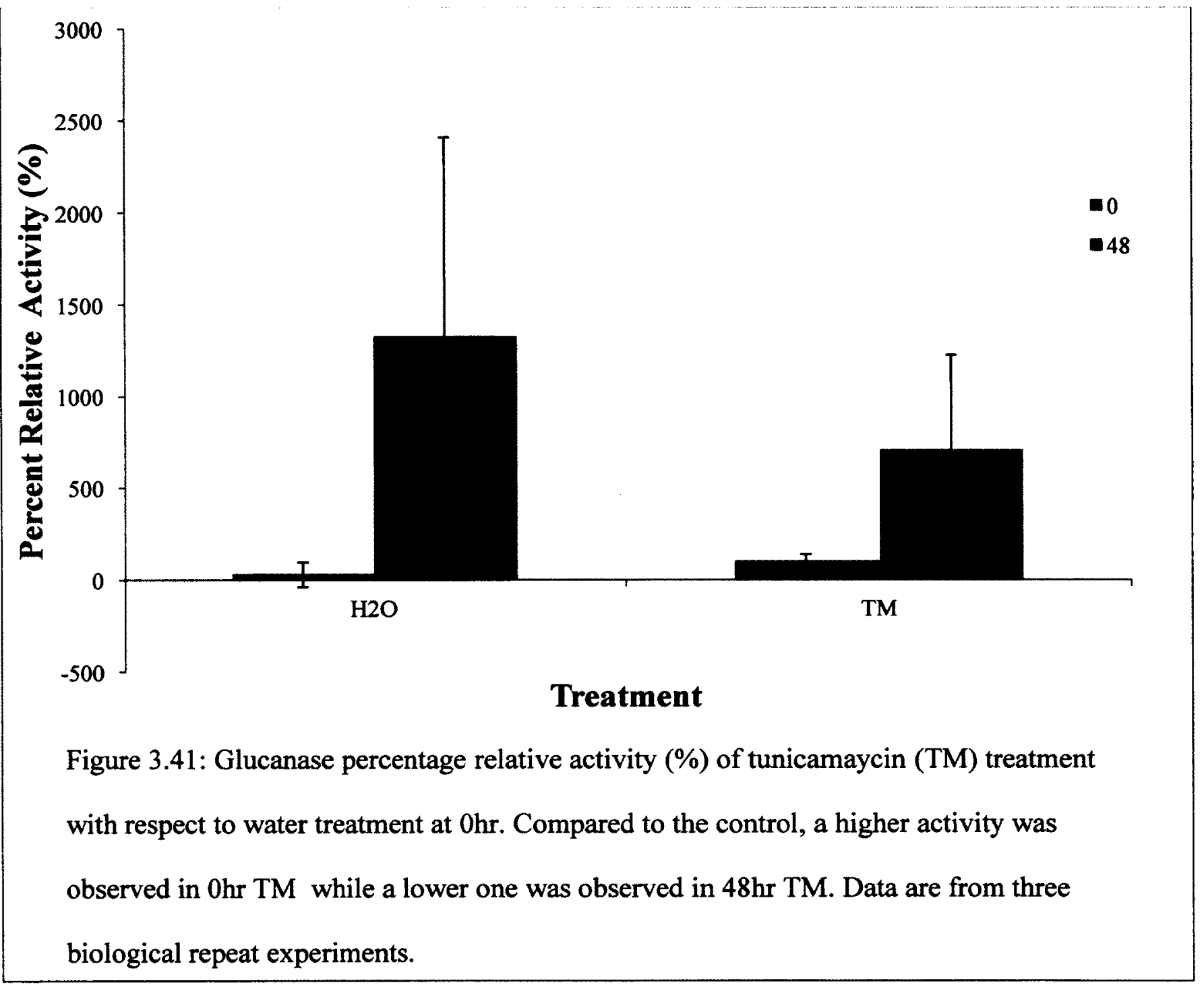




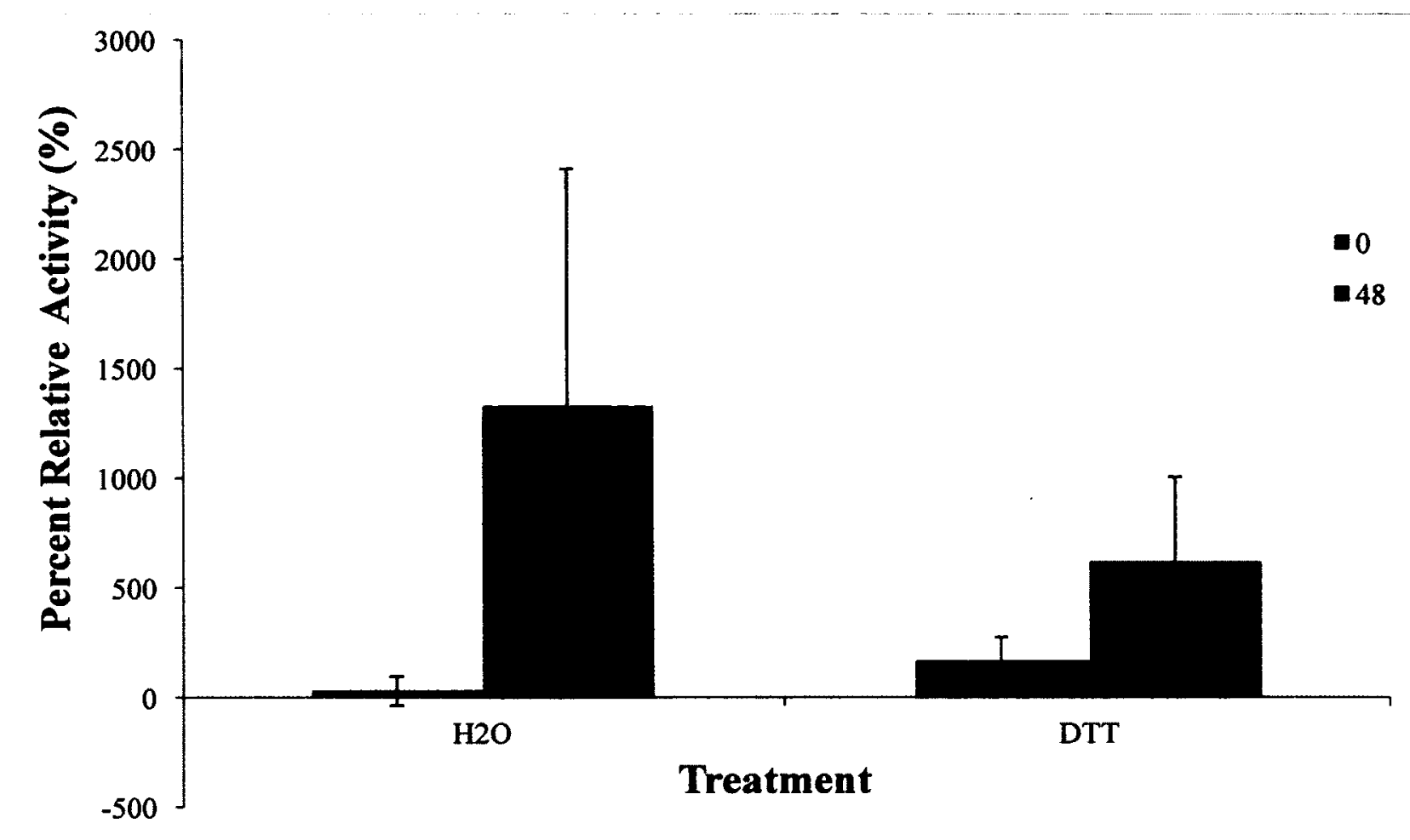

Figure 3.42: Glucanase percentage relative activity (\%) of dithiothreitol (DTT) treatment with respect to water treatment at $0 \mathrm{hr}$. Compared to the control, a higher activity was observed in $0 \mathrm{hr}$ DTT while a lower one was observed in $48 \mathrm{hr}$ DTT. Data are from three biological repeat experiments.

\subsubsection{Glutamine assay}

Both $0 \mathrm{hr}$ SA and DTT showed a lower activity than $0 \mathrm{hr} \mathrm{H}_{2} \mathrm{O}$ while $\mathrm{Ohr}$ TM recorded a higher activity. However, all $48 \mathrm{hr}$ treatments showed a lower activity than $48 \mathrm{hr} \mathrm{H}_{2} \mathrm{O}$ (Figures $3.43,3.44$, and 3.45$)$. 


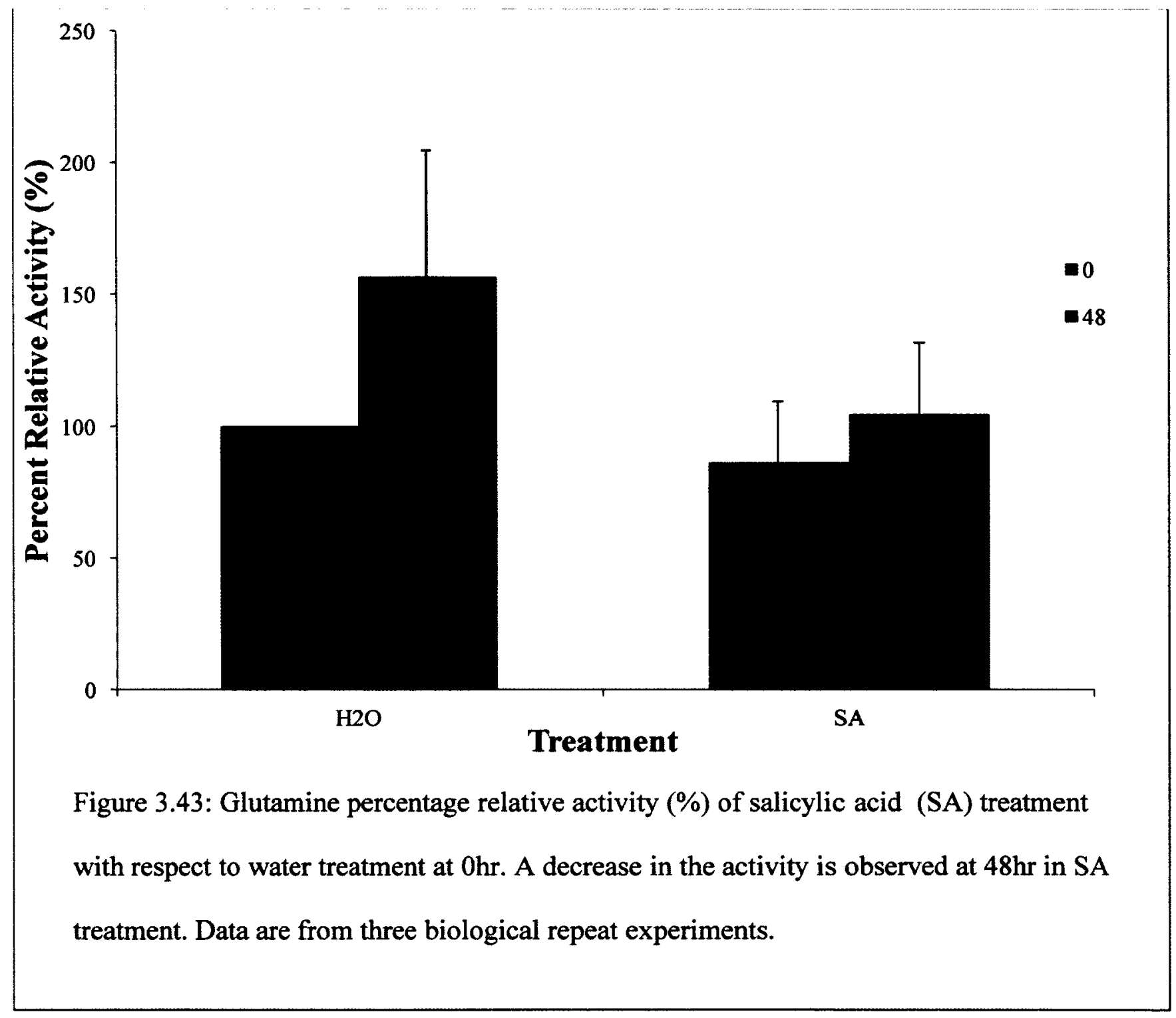




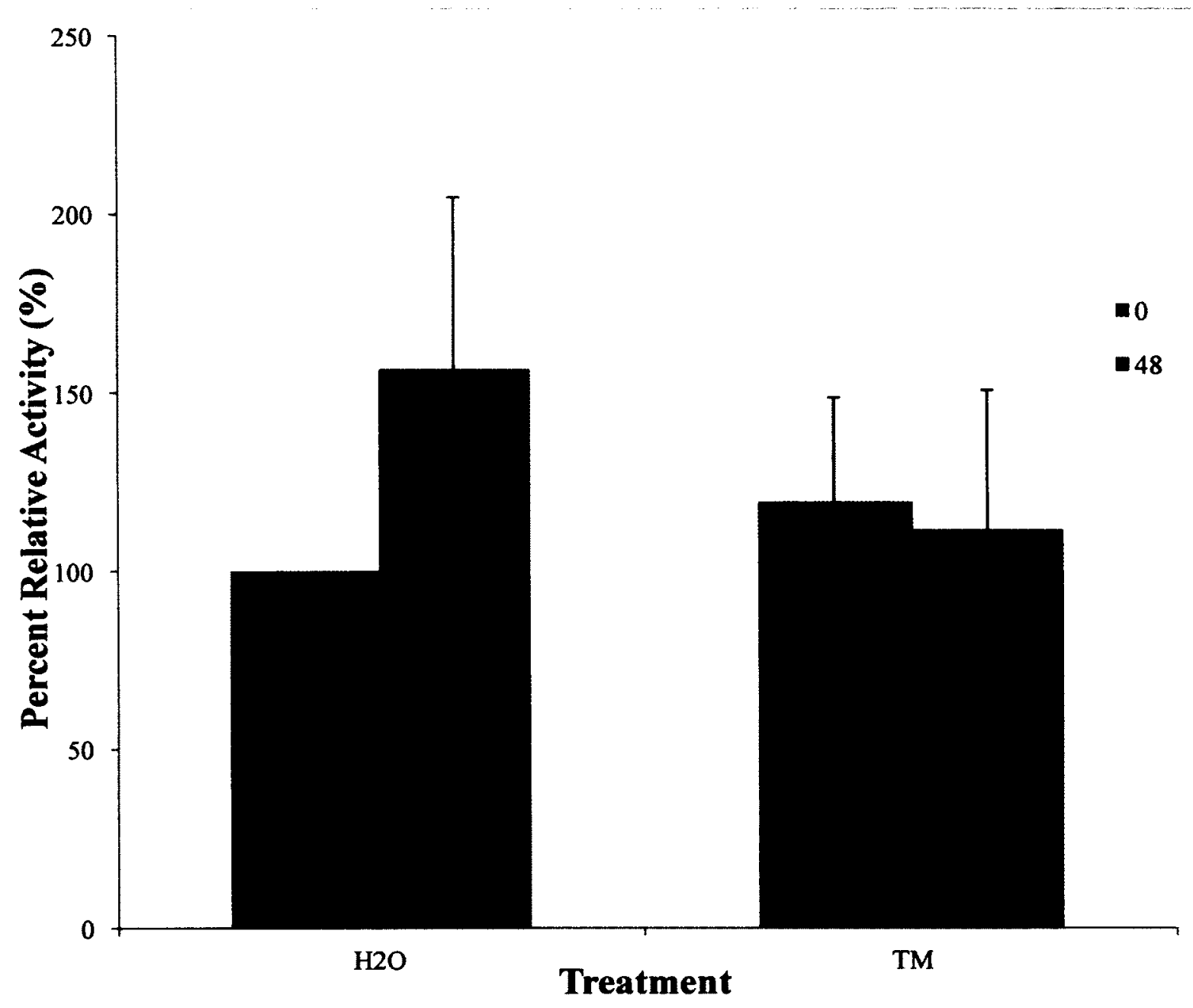

Figure 3.44: Glutamine percentage relative activity (\%) of tunicamycin (TM) treatment with respect to water treatment at $0 \mathrm{hr}$. A decrease in activity was observed in $48 \mathrm{hr}$ TM treatment. Data are from three biological repeat experiments. 


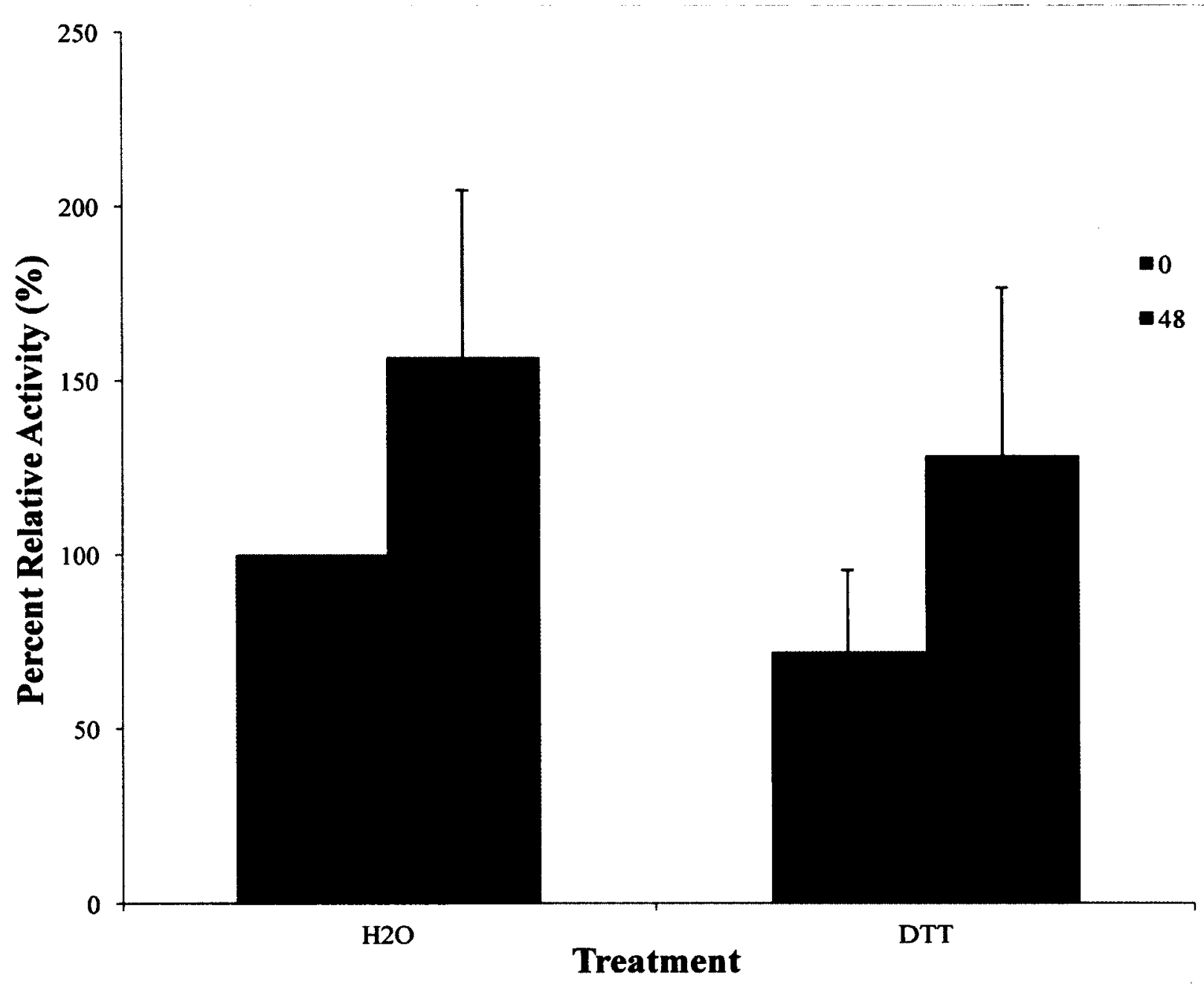

Figure 3.45: Glutamine percentage relative activity (\%) of Dithiothreitol (DTT) treatment with respect to water treatment at $0 \mathrm{hr}$. A decrease in activity was observed in DTT treatment. Data are from three biological repeat experiments. 


\section{Chapter IV}

\section{Discussion and Conclusion}

\subsection{MAPK regulated proteins}

Protein kinases are able to phosporylate the amino acids serine, threonine or tyrosine of specific proteins by covalently attaching a phosphate group to the side chain. MAPKs specifically regulate cellular activities by phosphorylating serines and threonines of target proteins. Some of these cellular activities include gene expression, mitosis, movement, metabolism, and programmed cell death. These MAPKs function as an on/off switch of substrate proteins. Such proteins include other protein kinases, phospholipases, transcription factors and cytoskeletal proteins (Orton et al., 2005).

There are three subfamilies of MAPKs, each involved with different targets and phosphorylated through different pathways by the MAPK cascade. Extracellular signal-regulated kinases (ERK) have two main proteins ERK1 and ERK2. These are believed to be involved in cell division and therefore their inhibitors may be anticancer agents. On the other hand, c-Jun $\mathrm{NH}_{2}$-terminal kinase includes $\mathrm{JNK} 1$, JNK2, and JNK3. JNKs are mainly distinguished as transcription regulators. The third group is $\mathrm{p} 38$ enzymes which include $\mathrm{p} 38 \alpha, \mathrm{p} 38 \beta, \mathrm{p} 38 \gamma$, and p38ס. These enzymes are activated by environmental stresses and are thus involved in immunity (Schulze et al., 2005).

Plant ER is responsible for making a suitable environment available for folding, oxidation, and oligomeric assembly of proteins. To do this, the ER has numerous folding enzymes, molecular chaperones, and folding sensors ( $\mathrm{Li}$ and Komatsu, 2000). Therefore, the newly synthesized and properly folded proteins are able to enter the next steps in being secreted 
(Li and Komatsu, 2000). Alternatively, if the proteins are incompletely folded or misfolded, they are inhibited from being exported. This unfolded protein response leads to an increase in the transcriptional expression of the ER chaperones and other target genes (Pedrazzini and Vitale, 1996). Binding immunoglobulin protein (BiP) is the most important ER chaperone found in plants. CRT, like calnexin, is considered as a non classical chaperone in plants due to its lectin binding properties (Chevet et al., 2001).

CRT was only recently discovered and studied in plants. Since then it has been determined that CRT is ubiquitous in plant cells. In fact, CRT mostly resides in larger quantities in the ER. It is very stable and has a long lifetime of $26 \mathrm{hr}$ as its half-life (Wyatt et al., 2002). Moreover, $\mathrm{CRT}$ is involved in $\mathrm{Ca}^{2+}$ regulation which is critical player in the regulation of the interactions of plants with their environment since it is a second messenger. This emphasizes the

contribution of the $\mathrm{ER}$ in $\mathrm{Ca}^{2+}$ homeostasis and signalling with or to the vacuole (Wyatt et al., 2002).

\subsection{Bioinformatics analysis}

Bioinformatics analysis contributes significantly to biochemical and molecular genetic studies of a gene, a protein, or a signalling network. Several aspects can be predicted using bioinformatics like physical and chemical properties, folding pattern, subcellular localization, protein interactions, and others. Due to researches done all over the world, it is possible for us to access data from thousands of experiments and thus better plan and design our own experimentation. However, when no research of our gene of interest is available, it is helpful to look at a gene in a different species homologous to our gene. In this case for example, CRT of Arabidopsis thaliana was studied. A phylogenetic tree was constructed showing Arabidopsis 
thaliana and Solanum lycopersicum CRT genes (Figure 3.1). As shown, AK321700.1 and SGNU578018 of Solanum lycopersicum are paralogs well as AT1G56340.1 and AT1G09210.1 of Arabidopsis thaliana. Consequently, AK321700.1 (LeCRT1) of Solanum lycopersicum was examined whenever applicable but mostly its Arabidopsis homolog AT1G56340 was examined when data for tomato CRT was not found. Similarly, SGN-U578018 (LeCRT2) of Solanum lycopersicum was examined whenever applicable and its Arabidopsis homolog AT1G09210.1 was examined when data for tomato CRT was not found. Since AK321700.1 was unsuccessfully amplified, it would be interesting to examine genomic DNA and check if AK321700.1 can be amplified there via PCR. This is because AK321700.1 may be a pseudo-gene. This can also be verified now that tomato has been recently fully sequenced (Tomato Genome Consortium, 2012).

\subsection{Analysis of Solanum lycopersicum CRT and its Arabidopsis homolog}

The motif analysis using ScanSite tool indicated the presence of potential kinase binding domains as well as multiple protein phosphorylation sites in AtCRT1a and AtCRT1b (Figures 3.2 and 3.7). The kinase binding domains suggest the presence of ERK-docking domains used by proteins to physically interact with MAPKs belonging to the ERK family. This analysis may support the role of kinases (ERK-type) in the regulation of the activity of this CRT. This explains the reasoning behind treating the leaves with an ERK docking domain inhibitor as later discussed. In addition, a potential SH2 binding site was predicted in AtCRT1b, which may suggest the possible interaction of this CRT with other proteins. This analysis may support the role of kinases in the regulation of the activity of this CRT (Figure 3.7).

The use of microarray data mining allowed us to examine the responses of CRT to various treatments or expression patterns in different developmental stages or in different tissues. 
If no data was found for either of tomato CRTs then their Arabidopsis CRT homologs were examined. Figures 3.3 and 3.8 indicate that SA enhanced CRT expression in Arabidopsis while FB1 did not. The effect of both these chemicals was examined using RT-PCR.

Figures 3.4 and 3.5 showed the expression of AK321700.1 in different parts of tomato as well as in different tissues during development. Figures 3.9 and 3.10 however showed CRT expression in different tissues and during development but for AtCRT1b as no data was present for SGN-U578018 tomato gene. No significant difference were found in all these analysis.

For the two Arabidopsis homologs, it was interesting to predict the protein-protein interactions with CRTs (Figures 3.6 and 3.11). As seen, AtCRT1a and AtCRT1b are predicted to interact with each other through co-expression, homology and text mining approaches enabled in the program. The function of both proteins is $\mathrm{Ca}^{2+}$ binding and unfolded protein binding (Tables 3.1 and 3.2). This may also indicate that different CRT proteins work together at different locations in the cell in order to fulfill their roles. In fact, these CRT proteins are isoforms and have distinctive tissue-dependent expression patterns and stress-related regulations (Persson et al., 2003). Table 3.1 and 3.2 may also suggest potential protein interaction partners and it would be interesting to see if some of these proteins will be detected in our pull-down experiment.

\subsection{CRT protein and motif analysis}

As shown in Figure 3.12, there are three main domains in plant CRTs. $\mathrm{N}$-domain constitutes the globular domain and is found at the extreme $\mathrm{N}$-terminus. $P$-domain constitutes the middle domain which is a sequence rich in proline amino acid. $C$-domain close to the $\mathrm{C}$-terminus represents the sequence rich in acidic residues. Moreover, a signal peptide sequence is found at the end of the $\mathrm{N}$-terminus and an ER-retention motif (HDEL) at the C-terminus which appears 
downstream of the sequence but is not shown in Figure 3.12. Also, three sequence tags of CRT were identified by mass spectrometry and are localized in the lumen of the ER. These tags are NLVFQFSVK, FYAISAEFPEFSNK, and YVGVELWQVK shown in Figure 3.12.

There are two highly conserved family signature motifs in plant CRTs within the $\mathrm{N}$ domain. Motif 1 is KHEQKLDCGGGYVKLL and motif 2 is IMFGPDICG, both of which are shown in Figure 3.12. In addition, correct folding of CRT requires the formation of intramolecular disulfide bridge which involves the conserved cysteine residues found in this domain (Jia et al., 2009).

The $P$-domain contains amino acid sequences similar to $\mathrm{Ca}^{2+}$ binding proteins and is responsible for the high-affinity and low-capacity $\mathrm{Ca}^{2+}$ binding. A recognized nuclear targeting sequence (PPKXIKDPX) marks the beginning of this domain. Two types of triplicate repeat motifs follow this sequence known as repeat A and B. In plant CRTs, repeat A has the motif sequence PXXIXDPXXKKPEXWDD while repeat $B$ has the motif sequence GXWXAXXIXNPXYK. It is assumed that the P-domain is involved in forming an extendedarm structure that interacts with chaperones found in the lumen of the ER. The tip of this extended arm in plant CRTs contains four amino acid residues (glutamic acid, aspartic acid, glutamic acid, and tryptophan) shown in Figure 3.12 that are important for chaperone activity of CRTs. This may indicate that CRT can act as a chaperone on its own or can interact with other chaperones to assist in their functions (Jia et al., 2009).

The least conserved domain the $C$-domain is very acidic and binds $\mathrm{Ca}^{2+}$ at high capacity. This proposes that the $C$-domain is involved in the storage of $\mathrm{Ca}^{2+}$ in addition to the regulation of protein retention in the ER lumen. 


\subsection{CRT and FB1 treatment}

It was predicted that whatever effect occurred on the expression in CRT in Arabidopsis would also occur on tomato CRT of the same homology.

FB1 is widely used in our lab and has been shown to activate MAPKs. Specifically, FB1 was shown to stimulate rapid, transient activation of MAPK (Wattenberg et al., 1996). So the effect of $5 \mu \mathrm{M}$ FB1 on CRT was examined and after $48 \mathrm{hr}$ incubation no effect seemed to take place at RT-PCR level (Figure 3.17). These same results were obtained upon repetition of the experiment and in fact this agrees with bioinformatics analysis on Arabidopsis CRT where no major change took place in expression (Figures 3.3 and 3.8). Consequently, tomato leaves were treated with other chemicals that affected expression.

\subsection{Effect of SA and ERK inhibitor on CRT expression}

SA, which is involved in plant defense against pathogen attacks, caused an increase in the expression of CRT (Figure 3.18). This increase may suggest that CRT is involved in plant defense. Studies suggest that CRT and its isoforms are involved in regulating plant defense against biotrophic pathogens making CRT connected to plant immunity (Qiu et al., 2012).

The ERK docking domain inhibitor (3-(2-Aminoethyl)-5-((4-ethoxyphenyl) methylene)2, 4-thiazolidinedione hydrochloride) was used to examine if SA-induced CRT changes is mediated by an ERK-like MAPK. Our previous over expression of tMEK2, which is one step upstream of MAPK, enhanced phosphorylation of CRT under heat stress (Xing lab, unpublished). Thus, the ERK inhibitor combined with SA was used to test for the relationship between SA, tMEK2, ERK-type MAPKs, and CRT. As specified earlier, SA helped increase the expression of CRT (Figure 3.18) and tMEK2 (Xing lab, unpublished). When ERK inhibitor is 
added, this increase could be reversed provided there is a direct relationship between CRT and ERK (Jia et al., 2009). As seen in Figure 3.18, CRT was not expressed in RT-PCR when the leaves were treated with $100 \mu \mathrm{M} \mathrm{SA}$ and $250 \mu \mathrm{M}$ ERKi. This indicates that the interaction between ERK and CRT was interrupted and therefore ERK is important for the expression of CRT confirming a relationship between MAPK and CRT. In their study, Sharma et al. (2004) found that CRT levels in rice leaves increased along with the increase of OsMAPK4 under cold stress. Therefore, it is plausible to assume that a relationship between CRT expression and MAPK exists.

\subsection{Endoplasmic reticulum (ER) stress-inducing agents (TM and DTT)}

Under stress conditions, URP occurs in the ER. These stress conditions can be manipulated by TM and DTT thus inducing UPR (Christensen et al., 2008). Studying the expression of CRT after this showed an increase by RT-PCR indicating a relationship between CRT and ER stress (Figure 3.19). This CRT expression was enhanced even more when SA was combined with either TM or DTT. Upon subjecting the leaves to an ER stress by TM or DTT, UPR is activated by the ER to signal for chaperone synthesis. These chaperones repair misfolded proteins to ensure only properly folded proteins leave the ER to other structures of the cell. CRT being a chaperone in unfolded protein binding is therefore naturally activated and an increase in expression is observed (Jeffery et al., 2011). When SA is added to the equation, CRT expression increases more in order to account for the extra stress. 


\subsection{Expression of CRT in E. coli}

The use of the TOPO TA vector allowed us to amplify our CRT gene (Figures 3.23 and 3.24) and produce the sticky cohesive ends by double digestion necessary for cloning into pET14b plasmid (Figure 3.25).

Expression cloning was conducted in order to study the protein function of CRT (Acevedo et al., 2013; Thomas et al., 2009). To produce many copies of the required protein within a host cell, pET expression system was used. Once activated, this bacterial plasmid pET vector facilitates large production of the targeted protein. Specifically $\mathrm{pET} 14 \mathrm{~b}$ vector is used and it has a His tag coding sequence at the $\mathrm{N}$-terminus and other unique sites (Figure 2.1). $\mathrm{CRT}$ was ultimately ligated into pET14b (Figures 3.29 and 3.30). In order to further confirm that the insert was correctly ligated into the vector, DNA sequencing of the insert is very useful. DNA sequencing was not used in this research and instead the orientation was checked by other methods.

BL21-CodonPlus (DE3)-RIPL competent cells were used for host transformation to express the target gene (Figure 3.36).Once induced, the target protein (CRT) of the foreign cell will be more distinguishable on the SDS-PAGE gel than the proteins of the BL21-CodonPlus (DE3)-RIPL host cells.

CRT was clearly expressed in induced and uninduced TCP. This expression was more pronounced in induced TCP due to IPTG (Figure 3.38). The expressed band falls between $48.8 \mathrm{KDa}$ and $37.1 \mathrm{KDa}$ of the protein marker. CRT is $41.8 \mathrm{KDa}$ in size and therefore is compatible with the position of the expressed band. In TCP, all proteins in the cell are shown. Uninduced TCP showed how much these proteins were expressed in the cell. As seen in Figure 
3.38, CRT was among the proteins mostly found in the cell thus inducing CRT expression showed a more intense band in induced TCP as expected.

Analysis of the medium fraction shows protein export or target protein leakage from the cells. Typically, no proteins should be found in MF and as seen in Figure 3.38 that was the case indicating no leakage occurred.

On the other hand, in SCF soluble proteins in the periplasm and cytoplasm will be expressed. The cell wall of the E.coli is gently disrupted to release active proteins without denaturing them. The main purpose of protein expression is often to obtain a high degree of accumulation of soluble product in the bacterial cell (Sorensen and Mortensen, 2005). Here, in SCF, CRT was successfully expressed a lot more in the induced sample. These results validate published data about CRT different localization in the cell and different functions (Wyatt et al., 2002).

Figure 3.39 shows CRT clearly probed by antibody at the same position detected in SDSPAGE (Figure 3.37). However, some other proteins of lower sizes were also detected. These are most likely due to the degraded CRT protein which would still be detected by the primary antibody. The breakdown of CRT is due proteases and this problem can be avoided by inhibiting these proteases during cell extraction (Outchkourov et al., 2004). Another way to reduce background would be by lowering the amount of protein loaded in the wells as well as titering the amount of the antibody.

\subsection{Regulation of enzymes}

We have examined two enzymes, $\beta$-1, 3-glucanase (PR2) and glutamine synthetase, under stress treatment. Glucanase is an important enzyme involved in pathogen cell wall 
degradation and is expected to increase during plant defense responses. The activity was tested by $\beta$-1, 3-glucanase (PR2) assay in leaves with different treatments (Figure 3.40). However, SA effect in our work is very inconclusive because of the high standard errors.

The relationship between SA and UPR was also examined by treating the leaves with TM or DTT (Figures 3.41 and 3.42 respectively). In both cases, $\beta$-1, 3-glucanase activity was higher in the $0 \mathrm{hr}$ treated leaves but lower in the $48 \mathrm{hr}$ treated leaves in TM and DTT compared to water. However, the activity in the same treatment increased as incubation time was higher. Here we tried to see if UPR (induced by TM or DTT) acted as a feedback mechanism to elevate the expression of PR2 enzymes. Our findings do not exactly support that partially due to the inconclusive data of SA effect. However, on the other hand, previous work found that TM treatment did not induce $\beta$-1, 3-glucanase gene in tobacco leaves indicating that UPR does not contribute in the production of PR proteins (Jelitto-Van Dooren et al., 1999).

Glutamine synthetase activity was also examined. Glutamine has several biochemical functions in the cell including protein synthesis and nitrogen donation. One of the reactions catalysed by glutamine synthetase leads to the formation of $\gamma$-glutamylhydroxamate. Generally, this compound is used in order to determine enzyme activity:

$$
\text { Glutamate }+\mathrm{NH}_{2} \mathrm{OH}+\mathrm{ATP} \longrightarrow \boldsymbol{\gamma} \text {-glutamylhydroxamate }+\mathrm{ADP}+\mathrm{Pi}
$$

The formed product $\gamma$-glutamylhydroxamate can be measured using colorimetry based on its reaction with ferric chloride. In order for this reaction to work, an ATP-generating system is added to the reaction mixture to reconvert ADP into ATP because a high ADP to ATP ratio inhibits glutamine synthetase (Miflin and Habash, 2002). In all treatments except $0 \mathrm{hr} \mathrm{TM}$, the activity of glutamine synthetase was lower than control (water) (Figures $3.43,3.44$, and 3.45 ). 
These results were expected and are agreeable with Aledo's findings (2004) that glutamine synthesis decreases when the plant is dealing with a stress. Consequently the activity of glutamine synthetase decreases as well. More experimentation should be performed especially with TM treatment to decrease standard error and confirm the results.

\subsection{Conclusion and future work}

Our data have shown that SA, TM, and DTT all affect the expression of CRT at the transcriptional level while FB1 does not. Moreover, this expression is more distinct when SA is combined with either TM or DTT. This showed that CRT, being a chaperone, is activated or signals the activation of other chaperones for UPR due to ER stress as well as biotic stress. Moreover, we found that CRT is involved in MAPK pathways. The expression of CRT was totally lost when ERK inhibitor was added. Even with SA treatment the increase in CRT expression was not reserved. This suggested that CRT expression is dependent on ERK.

Figure 3.20 shows that SA had the highest percentage of integrated density value meaning it affects the expression of CRT. It would be helpful to repeat PCR experimentation using real time PCR as this can quantitatively show us the progress of CRT amplification under each treatment.

Cloning CRT into pET14b vector was successful as well as expression of the protein in the BL21-CodonPlus (DE3)-RIPL cells. SDS-PAGE and Western blot both confirmed the expression of this protein. It was anticipated that whatever the interactions between Arabidopsis $\mathrm{CRT}$ and other proteins may also occur with tomato CRT. Therefore in the future, proteinprotein interaction with CRT can be studied by pull-down analysis. pET14b has a 6-His tag which is partially negatively charged because of the $\mathrm{N}$ atom in the imidazole ring in the histidine 
residues. These residues bind to the positively charged $\mathrm{Ni}^{++}$ions in Ni-NTA agarose. The target protein can then be eluted and protein-protein interactions can be examined.

Although glucanase and glutamine assays had very large standard errors, glutamine synthetase assay results were more promising. The activity of PR2 was expected to increase from the control under stress conditions but that was not the case. In glutamine synthetase however the activity decreased as predicted to direct energy spending on dealing with the stress. More data needs to be obtained to confirm these results. It is possible that the infiltration method that was applied in my study induced a wound response. Also, the method may not be well stabilized. Our lab is now testing other leave treatment methods including spray and Q-tip wiping.

In the future, it would be interesting to repeat this work on the hypocotyls instead of the leaves of tomatoes as hypocotyls are more consistent and uniform cell types and can be germinated on agar plates before being harvested. 


\section{References}

Abbas H.K., Tanaka T., Duke S.O., Porter J.K., Wray E.M., Hodges L., Sessions A.E., Wang E., Merrill Jr A.H. and Riley R.T. 1994. Fumonisin- and AAL-toxin-induced disruption of sphingolipid metabolism with accumulation of free sphingoid bases. Plant Physiology. 106: 1085-1093.

Acevedo J.P., Rodriguez V., Saavedra M., Muñoz M., Salazar O., Asenjo J.A. and Andrews B.A. 2013. Cloning, expression and decoding of the cold adaptation of a new widely represented thermolabile subtilisin-like protease. Journal of Applied Microbiology. 114: 352-363.

Aledo J. C. 2004. Glutamine breakdown in rapidly dividing cells: Waste or investment? BioEssays. 26: 778-785.

Anil V. S. and Rao K. S. 2001. Calcium-mediated signal transduction in plants: A perspective on the role of $\mathrm{Ca}^{2+}$ and CDPKs during early plant development. Journal of Plant Physiology. 158: 1237-1256.

Asai T., Stone J.M., Heard J.E., Kovtun Y., Yorgey P., Sheen J. and Ausubel F.M. 2000. Fumonisin B1-induced cell death in Arabidopsis protoplasts requires jasmonate-, ethylene-, and salicylate-dependent signaling pathways. Plant Cell. 12: 1823-1835.

Chen Z., Zheng Z., Huang J., Lai Z., and Fan B. 2009. Biosynthesis of salicylic acid in plants. Plant Signaling and Behavior. 4: 493-496.

Chevet E., Cameron P.H., Pelletier M.F., Thomas D.Y. and Bergeron J.J. 2001. The endoplasmic reticulum: integration of protein folding, quality control, signaling and degradation. Current Opinion in Structural Biology. 11:120-124.

Christensen A., Svensson K., Persson S. , Jung J., Michalak M., Widell S. and Sommarin M. 2008. Functional characterization of Arabidopsis calreticulin1 a: a key alleviator of endoplasmic reticulum stress. Plant Cell Physiology. 49: 912-924.

Desai K., Sullards M.C., Allegood J., Wang E., Schmelz E.M., Hartl M., Humpf H.U., Liotta D.C., Peng Q. and Merrill A.H. 2002. Fumonisins and fumonisin analogs as inhibitors of ceramide synthase and inducers of apoptosis. Molecular and Cell Biology of Lipids. 1585:188192.

Doxey A., Yaish M., Moffatt B., Griffith M., and McConkey B. 2007. Functional divergence in the Arabidopsis $\beta$-1,3-glucanase gene family inferred by phylogenetic reconstruction of expression states. Molecular Biology and Evolution. 24:1045-1055.

Jeffery E., Peters L.R., and Raghavan M. 2011. The polypeptide binding confirmation of calreticulin facilitates its cell-surface expression under conditions of endoplasmic reticulum stress. Journal of Biological Chemistry. 286: 2402-2415. 
Jelitto-Van Dooren E., Vidalb S., and Deneckea J. 1999. Anticipating endoplasmic reticulum stress: a novel early response before pathogenesis-related gene induction. The Plant Cell. 11: 1935-1943.

Jia X., He L., Jing R., and Li R. 2009. Calreticulin: conserved protein and diverse functions in plants. Physiologia Plantarum. 136: 127-138.

Jonak C., Ligterink W. and Hirt H. 1999. MAP kinases in plant signal transduction. Cellular and Molecular Life Sciences. 55: 204-213

Jung J., Fritig B., and Hahne C. 1993. Sunflower (Helianthus annuus L.) Pathogenesis-related proteins: induction by Aspirin (scetylsalicylic acid) and characterization. Plant Physiology. 101: 873-880.

Kimura S. and Sinha N. 2008. Tomato (Solanum lycopersicum): a model fruit-bearing crop. Cold Spring Harbor Protocols. doi: 10.1101/pdb.emo105.

Levy A., Guenoune-Gelbart D., and Epel B. 2007. $\beta$-1,3-glucanases: plasmodesmal gate keepers for intercellular communication. Plant Signal Behaviour. 2(5): 404-407.

Li Z. and Komatsu S. 2000. Molecular cloning and characterization of calreticulin, a calciumbinding protein involved in the regeneration of rice cultured suspension cells. European Journal of Biochemistry. 267:737-745

Liu X., Xu F., Fu Y., Liu F., Sun S. and Wu X. 2006. Calreticulin induces delayed cardioprotection through mitogen- activated protein kinases. Proteomics. 6:3792-3800.

Machrill, J. 2011. Oxysterols and calcium signal transduction. Chemistry and physics of lipids. 164: 488-495.

Mazarei M., Elling A.A., Maier T.R., Puthoff D.P., and Baum T.J. 2007. GmEREBP1 is a transcription factor activating defense genes in soybean and Arabidopsis.Molecular PlantMicrobe Interactions. 20: 107-119.

Michalak M., Robert-Parker J. M., and Opas M. 2002. $\mathrm{Ca}^{2+}$ signaling and calcium binding chaperones of the endoplasmic reticulum. Cell Calcium. 32: 269-278.

Michalak M., Groenendyk J., Szabo E., Gold L., and Opas M. 2009. Calreticulin, a multi-process calcium-buffering chaperone of the endoplasmic reticulum. Biochemical Journal. 417: 651-666.

Miflin B. and Habash D. 2002. The role of glutamine synthetase and glutamate dehydrogenase in nitrogen assimilation and possibilities for improvement in the nitrogen utilization of crops. Journal of Experimental Botany. 53: 979-987. 
Müller-Taubenberger A., Lupas A., Li H., Ecke M. Simmeth E. and Gerisch G. 2001. Calreticulin and calnexin in the endoplasmic reticulum are important for phagocytosis. The EMBO Journal. 20: 6772-6782.

Novagen, 2005. pET System Manual. $10^{\text {th }}$ edition. Darmstadt, Germany.

Orton R.J., Sturm O.E., Vyshemirsky V., Calder M., Gilbert D.R., and Kolch W. 2005. Computational modelling of the receptor-tyrosine-kinase-activated MAPK pathway. The Biochemical Journal. 392: 249-261

Outchkourov N., Jan de Kogel W., Schuurman-de Bruin A., Abrahamson M. and Jongsma M. 2004. Specific cysteine protease inhibitors act as deterrents of western flower thrips, Frankliniella occidentalis (Pergande), in transgenic potato Nikolay. Plant Biotechnology Journal. $2: 439-448$.

Pedrazzini E. and Vitale A. 1996. The binding protein (BiP) and the synthesis of secretory proteins. Plant Physiology and Biochemistry. 34:207-216.

Persson S., Rosenquist M., Svensson K., Galvão R., Boss W.F., and Sommarin M. 2003. Phylogenetic analyses and expression studies reveal two distinct groups of calreticulin isoforms in higher plants. Plant Physiology. 133:1385-96.

Pitzschke A., Schikora A., and Hirt H. 2009. MAPK cascade signalling networks in plant defence. Current Opinion in Plant Biology. 12: 1-6.

Poovaiah B.W. and Reddy AS. 1993. Calcium and signal transduction in plants. Critical Reviews in Plant Sciences. 12:185-211.

Qiu Y., Xi J., Du L., and Poovaiah B.W. 2012. The function of calreticulin in plant immunity: New discoveries for an old protein. Plant Signaling and Behavior. 7: 907- 910.

Reece J. and Campbell N. 2002. Biology. San Francisco: Benjamin Cummings.

Schramek, H. 2002. MAP Kinases: from intracellular signals to physiology and disease. News in Physiological Sciences. 17:62-67.

Schulze W.X., Deng L., and Mann M. 2005. Phosphotyrosine interactome of the ErbB-receptor kinase family. Molecular Systems Biology 1: 1-13.

Sharma A., Isogai M.,Yamamoto T., Sakaguchi K., Hashimoto J., and Komatsu S. 2004. A Novel Interaction between Calreticulin and Ubiquitin-Like Nuclear Protein in Rice. Plant Cell Physiology. 45: 684-692

Sorensen H. and Mortensen K. 2005. Soluble expression of recombinant proteins in the cytoplasm of Escherichia coli. Microbial Cell Factories. 4:1-8. 
Spiegel S. and Merrill Jr A.H. 1996. Sphingolipid metabolism and cell growth regulation. FASEB Journal. 10: 1388-1397.

Stone J.M., Heard J.E., Asai T. and Ausubel F.M. 2000. Simulation of fungal-mediated cell death by fumonisin B1 and selection of fumonisin B1-resistant (fbr) Arabidopsis mutants. Plant Cell. 12: 1811-1822.

Thomas, S., N. Thirumalapura, E.C. Crossley, N. Ismail, and D.H. Walker. 2009. Antigenic protein modifications in Ehrlichia. Parasite Immunology. 31: 296-303.

Thurston G., Regan S., Rampitsch C. and Xing T. 2005. Proteomic and phosphoproteomic approaches to understanding plant-pathogen interactions. Physiological and Molecular Plant Pathology. 66:3-11.

Tomato Genome Consortium. 2012. The tomato genome sequence provides insights into fleshy fruit evolution. Nature. 485: 635-641.

Wattenberg E., Badria F.A., Shier W.T. 1996. Activation of mitogen activated protein kinase by the carcinogenic mycotoxin Fumonosin B1. Biochemical and Biophysical Research Comminications. 227:622-627.

Wu C., Leubner-Metzger G., Meins F, and Bradford K. 2001. Class I beta-1,3-glucanase and chitinase are expressed in the micropylar endosperm of tomato seeds prior to radicle emergence. Plant Physiology. 126:1299-1313.

Wu X., Liu X., Zhu X., and Tang C. 2007. Hypoxic preconditioning induces delayed cardioprotection through p38 MAPK-mediated calreticulin upregulation. Shock. 27:572-577.

Wyatt S.E., Tsou P.L., and Robertson D. 2002. Expression of the high capacity calcium-binding domain of calreticulin increases bioavailable calcium stores in plants. Transgenic Research. 11:1-10.

Xiao S. and Chye M.L. 2011. Overexpression of Arabidopsis ACBP3 enhances NPR1-dependent plant resistance to Pseudomonas syringe pv tomato DC3000. Plant Physiology. 156:2069-2081.

Xing T., Ouellet T. and Miki B.L. 2002. Towards genomic and proteomic studies of protein phosphorylation in plant-pathogen interactions. Trends in Plant Science. 7:224-230.

Yang K., Liu Y. and Zhang S. 2001. Activation of a mitogen-activated protein kinase pathway is involved in disease resistance in tobacco. Proceedings of National Academy of Science USA. 98:741-746.

Yoo H.-S., Norred W.P., Showker J.L., Riley R.T., 1996. Elevated sphingoid bases and complex sphingolipid depletion as contributing factors in fumonisin-induced cytotoxicity. Toxicological and Applied Pharmacology. 138:211-218. 
Zarich N, Oliva J. L., Martínez N., Jorge R., Ballester A., Gutiérrez-Eisman S., Garcia-Vargas S., and Rojas J.M. 2006. Grb2 is a negative modulator of the intrinsic Ras-GEF activity of hSos1. Molecular Biology of the Cell. 17:3591-3597

Zhang S. and Klessig D.F. 1997. Salicylic acid activates a 48-kD MAP kinase in tobacco. Plant Cell. 9:809-824

Zhang S. and Klessig D.F. 2001. MAPK cascades in plant defense signaling. Trends in Plant Science. 6:520-527.

Zhang S. and Liu Y. 2001. Activation of salicylic acid-induced protein kinase, a mitogen activated protein kinase, induces multiple defense responses in tobacco. Plant Cell. 13:18771889. 